UNIVERSIDADE DE SÃO PAULO

FACULDADE DE MEDICINA DE RIBEIRÃO PRETO

LEDA MARIA TAVARES ALVES

ESTUDO DA DEGLUTIÇÃO EM PACIENTES COM DISTONIA LARÍNGEA ANTES E APÓS O TRATAMENTO COM TOXINA BOTULÍNICA

Ribeirão Preto 


\title{
ESTUDO DA DEGLUTIÇÃO EM PACIENTES COM DISTONIA LARÍNGEA ANTES E APÓS O TRATAMENTO COM TOXINA BOTULÍNICA
}

\begin{abstract}
Tese apresentada à Faculdade de Medicina de Ribeirão Preto da Universidade de São Paulo para obtenção do título de Doutor.
\end{abstract}

Área de concentração: Morfofisiologia de Estruturas Faciais.

Orientador: Prof. Dr. Roberto Oliveira Dantas

\section{Ribeirão Preto}


Autorizo a reprodução e divulgação total ou parcial deste trabalho, por qualquer meio convencional ou eletrônico, para fins de estudo e pesquisa, desde que citada a fonte.

Alves, Leda Maria Tavares

Estudo da deglutição em pacientes com distonia laríngea antes e após o tratamento com toxina botulínica. Ribeirão Preto, 2013.

90 p. : il. ; $30 \mathrm{~cm}$

Tese de Doutorado apresentada à Faculdade de Medicina de Ribeirão Preto/USP. Área de concentração: Morfofisiologia de Estruturas Faciais.

Orientador: Dantas, Roberto Oliveira.

1. Distonia laríngea. 2. Toxina botulínica. 3. Deglutição.

4. Videofluoroscopia. 5. Eletromiografia. 
Nome: ALVES, Leda Maria Tavares.

Título: Estudo da deglutição em pacientes com distonia laríngea antes e após o tratamento com toxina botulínica.

Tese apresentada à Faculdade de Medicina de Ribeirão Preto da Universidade de São Paulo para obtenção do título de Doutor em Morfofisiologia de Estruturas Faciais.

Aprovado em:

Banca Examinadora

Prof. Dr. Instituição:

Julgamento: Assinatura:

Prof. Dr. Instituição:

Julgamento: Assinatura:

Prof. Dr. Instituição: Julgamento: Assinatura:

Prof. Dr. Instituição:

Julgamento: Assinatura:

Prof. Dr. Instituição: Julgamento: Assinatura: 


\section{DEDICATÓRIA}

Quero dedicar este trabalho primeiramente a Deus, que me envolveu com sua paz, quando a aflição quis persistir, renovou minhas esperanças quando as forças estavam acabando...e com sua infinita bondade, sabedoria e misericórdia, me deu forças, fé e coragem para que eu pudesse finalizar mais uma etapa de minha vida, com a realização deste trabalho. Toda luta, toda vitória... tudo enfim, é do Senhor.

Quero também dedicar este trabalho aos Meus Pais, pois sem seus exemplos de coragem, honestidade, dedicação, humildade perseverança, integridade, fé...eu não teria chegado até aqui. Obrigada por me apoiarem, nos momentos de dificuldades, e se fazerem presentes, mesmo á distância, em todos os momentos no decorrer deste trabalho, por entenderem minhas ausências em alguns momentos e pela imensa demonstração de carinho quando me fazia presente. Vocês são tudo pra mim...Eu amo muito vocês!!! 


\section{AGRADECIMENTOS}

Primeiramente, quero agradecer ao Prof. Dr. Roberto Oliveira Dantas, pela atenção e paciência demonstradas a mim no decorrer deste trabalho, pois o meu contato com o senhor é, e sempre será um eterno aprendizado. Quero também, deixar exposta a minha profunda admiração pela sua pessoa e por seu trabalho, que no decorrer destes anos pude conhecer um pouco mais...pois também acredito que "O futuro não é um lugar aonde estamos indo, mas um lugar que estamos criando. $O$ caminho para ele não é encontrado, mas construído e o ato de fazê-lo muda tanto o realizador quanto o destino". Tenha a certeza que as mudanças se iniciaram, nessa humilde realizadora que aqui vos escreve, com a certeza de sua importante colaboração no decorrer da realização deste trabalho. Muito obrigada por tudo do fundo do coração!

Agradeço ao Prof. Dr. Hilton Marcos Alves Ricz, primeiramente por ter aceitado participar neste trabalho, por todos os esclarecimentos, e também pela atenção e generosidade disponibilizadas a mim no decorrer do mesmo. Muito obrigada!

Agradeço a Prof. Dra. Luciana Vitaliano Voi Trawitzki, por sua relevante colaboração neste trabalho e por ter aceitado participar desta banca. Meus agradecimentos por tudo!

Agradeço a Profa. Dra. Elizabete Carrara de Angelis, pelo aceite e disponibilidade em participar desta banca, pois sei o quanto sua vida é atribulada, por sua atenção, e importante colaboração para este trabalho...Muito obrigada!

Agradeço ao Prof. Dr. Agricio Nubiato Crespo, pela sua significante colaboração para este estudo, por sua atenção e também por ter aceitado integrar esta banca...Muito obrigada!

Agradeço ao Dr. Guilherme, e a todas as funcionárias do ambulatório da Neurofisiologia, pela paciência e atenção demonstradas a min durante todas as semanas que estive selecionando e observando os pacientes neste local. Vocês são profissionais muito dedicados e foram muito simpáticos e prestativos comigo quando precisei.

Agradeço aos amigos e parentes de minha terra natal, principalmente ao meu irmão José Eduardo e minha cunhada Ana Claudia, pelo incentivo e torcida para que tudo desse certo, mesmo à distância, e aos amigos que conquistei aqui em Ribeirão Preto...amigos da fé e do edifício...Muito obrigada pelos momentos agradáveis que me proporcionaram, pelos auxílios prestados, pelas conversas, orações, telefonemas...enfim por tudo que fizeram por min. Não se esqueçam que sempre me lembrarei de vocês em minhas orações, e que estarão sempre em meu coração onde quer que eu esteja!

Quero agradecer também a Mayara, que colaborou com as análises estatísticas para que eu pudesse finalizar este trabalho, e ao Robson P. Araujo, pelas orientações e auxilio com a revisão bibliográfica. Desejo muito sucesso a vocês! 
Agradeço as amigas que conquistei durante a pós-graduação, principalmente a Marcia...e seu Esposo, a Luana, a Weslânia, a Isabela e a Aline pelos auxílios de forma direta e indireta nos momentos que precisei. Valeu por tudo viu!

Agradeço a Vannesa, por sua colaboração em todos os momentos da coleta, com suas informações e comentários sobre os pacientes, enfim por tudo que fez por mim...Meu muito obrigada!

Agradeço à Liciane, por me permitir realizar as análises dos pacientes nos intervalos de seus atendimentos e até pelo empréstimo de CD, quando as coisas não corriam bem com o funcionamento do aparelho...Desejo muito sucesso a você!

Agradeço também ao Francisco, que me fez vivenciar novas experiências e acreditar na sincera e eterna amizade. Tenho uma profunda admiração por você. Você sem dúvida é um grande exemplo, e uma grande lição de vida para muitos viu! Muito obrigada por sua existência e pela oportunidade de ter Ihe conhecido um dia!

Agradeço à Keila, ao Marcelo, e a todos os funcionários do Setor de Radiologia deste hospital, pela imensa colaboração, disponibilidade e auxilio prestados a mim no decorrer deste trabalho...sem vocês este trabalho não chegaria ao término! Muito obrigada de coração!

Agradeço a todas as funcionárias do Setor de Cabeça e Pescoço do ambulatório desse hospital, pelo grande auxílio, paciência e incentivos prestados a mim no decorrer dessa coleta. Vocês, além de me ajudarem muito, se tornaram minhas amigas viu!

Quero finalizar, fazendo um agradecimento especial a todos os participantes deste trabalho, pois sem vocês não haveria trabalho algum... 
Dores mantêm você humano;

Quedas te mantêm humilde;

Provações te mantêm forte;

Mas, somente Deus te mantém prosseguindo!

Desconhecido

A felicidade aparece para aqueles que choram,

Para aqueles que se machucam,

Para aqueles que buscam e tentam sempre.

E para aqueles que reconhecem a importância das pessoas que passam por suas vidas.

Clarice Lispector

Muito embora seu coração esteja doendo, sorria.

Charles Chaplin

Eu segurei muitas coisas em minhas mãos, e eu perdi tudo; mas tudo o que eu coloquei nas mãos de Deus eu ainda possuo.

Martin Luther king 


\section{RESUMO}

ALVES, L. M. T. Estudo da deglutição em pacientes com distonia laríngea antes e após o tratamento com toxina botulínica. 2013. 90 f. Tese (Doutorado) Faculdade de Medicina de Ribeirão Preto, Universidade de São Paulo, Ribeirão Preto, 2013.

A distonia é uma síndrome que consiste de contrações musculares involuntárias que resultam em movimentos distorcidos e repetitivos e/ou posturas anormais. $O$ tratamento pode ser por farmacoterapia, com drogas anticolinérgicas ou com a injeção de toxina botulínica no grupo de músculos afetados. O objetivo do trabalho foi avaliar a deglutição nos pacientes com distonia laríngea, antes e após o tratamento com a toxina botulínica. Nossa hipótese foi que a toxina botulínica modificaria a deglutição dos pacientes com distonia laríngea. Foram avaliados 17 indivíduos adultos, acima de 18 anos de idade, com diagnóstico clínico de distonia laríngea antes e após o tratamento com o uso de toxina botulínica do tipo A, e 20 indivíduos adultos saudáveis como controles. Os participantes foram submetidos à anamnese fonoaudiológica e avaliação videofluoroscópica da deglutição. Os pacientes com distonia foram avaliados antes e 30 dias após a injeção de toxina botulínica, guiada por eletromiografia. $\mathrm{Na}$ videofluoroscopia foram avaliadas 6 deglutições de $5 \mathrm{~mL}$, sendo 3 na consistência líquida (sulfato de bário 100\%, e 3 na consistência pastosa $(3 \mathrm{~g}$ do espessante alimentar ThickenUp Clear, em $50 \mathrm{~mL}$ de sulfato de bário $100 \%$ ) oferecidas em uma colher. A ordem das deglutições foi aleatória. Foram estudadas as fases oral e faríngea da deglutição, com registro de 30 quadros por segundo. Os pacientes com distonia laríngea apresentaram aumento de resíduos na região oral e em valécula e maior número de deglutições. Os pacientes apresentaram tempo de trânsito faríngeo (TTF) menor do que os controles $(p<0,01)$, para os bolos nas consistências líquida e pastosa. O TTF foi menor após aplicação do que antes da aplicação da toxina botulínica, quando da deglutição do bolo pastoso. Portanto, concluiu-se que os pacientes com distonia laríngea, comparado a controles, têm trânsito mais rápido pela faringe, aumento de resíduos na região oral e em valécula e maior número de deglutições para o mesmo volume. Trinta dias após a aplicação da toxina botulínica foi observado diminuição da duração do trânsito pela faringe, com o bolo pastoso, e resposta tardia do movimento do osso hióide em relação à chegada do bolo na faringe.

Palavras Chave: Distonia laríngea. Toxina botulínica. Deglutição. Videofluoroscopia. Eletromiografia. 


\begin{abstract}
ALVES, L. M. T. Study of swallowing in patients with laryngeal dystonia before and after treatment with botulinum toxin. 2013. $90 \mathrm{f}$. Doctoral Thesis - School of Medicine of Ribeirão Preto, University of São Paulo, Ribeirão Preto, 2013.

Dystonia is a syndrome consisting of involuntary muscle contractions that result in distorted and repetitive movements and/or abnormal postures. Treatment may be by pharmacotherapy with anticholinergic drugs or with the injection of botulinum toxin in the affected muscle group. The aim of this study was to evaluate swallowing in patients with dystonia before and after treatment with botulinum toxin. Our hypothesis was that botulinum toxin modify the swallowing of patients with spastic dystonia. Seventeen adult subjects over the age of 18 years with clinically diagnosed dystonia were evaluated before and after treatment with botulinum toxin type $A$ and compared to 20 healthy adults as controls. Participants underwent phonologic anamnesis and videofluoroscopy assessment of swallowing. Patients with dystonia were assessed before and 30 days after injection of botulinum toxin, guided by electromyography. In fluoroscopy, 6 swallows were evaluated of $5 \mathrm{ml}$ : 3 in a liquid consistency (100\% barium sulfate) and 3 in a pasty consistency ( $3 \mathrm{~g}$ of food thickener, ThickenUp Clear) in $50 \mathrm{~mL}$ of $100 \%$ barium sulfate, offered on a spoon. The oral and pharyngeal phases of swallowing were studied from swallows of random order, with registration of 30 frames per second. Patients with dystonia showed an increase of residue in the oral region and vallecula and greater number of multiple swallows. Patients had less pharyngeal transit time (PTT) than controls $(p<0.01)$ for boluses of liquid and pasty consistencies. PTT was lower after the application of botulinum toxin than before with the swallowing of a pasty bolus. It was concluded that patients with dystonia, compared to controls, have more rapid transit through the pharynx, increased residues in the oral region and vallecula and a greater number of swallows for the same volume. Thirty days after the botulinum toxin, it was observed a shorter pharyngeal transit time with paste bolus, and delayed hyoid movement response to bolus presence in pharynx.
\end{abstract}

Keywords: Laryngeal dystonia. Botulinum toxin. Swallowing. Fluoroscopy. Electromyography. 


\section{LISTA DE FIGURAS}

Figura 1 - Imagem do aparelho videofluoroscópico utilizado para avaliação da deglutição dos participantes do estudo

Figura 2 - Imagem da posição de uma voluntária durante a realização do exame videofluoroscópico da deglutição

Figura 3 - Imagem dos materiais utilizados durante a realização do exame videofluoroscópico nos participantes do estudo

Figura 4 - Gráfico de comparação do tempo de transito faríngeo após a deglutição de bolo líquido e pastoso nos participantes do estudo

Figura 5 - Gráfico da relação do inicio da fase faríngea com o inicio do movimento do osso hióide após a deglutição de bolo líquido e pastoso nos grupos do estudo. 


\section{LISTA DE TABELAS}

Tabela 1 - Comparações dos grupos controle e pacientes com distonia laríngea pré e pós-aplicação da toxina botulínica, considerando os tempos de trânsito para a consistência líquida 36

Tabela 2 - Comparações dos grupos controle e pacientes com distonia laríngea pré e pós-aplicação da toxina botulínica considerando os tempos de trânsito para a consistência pastosa

Tabela 3 - Comparação entre os grupos controle, pré e pós-aplicação da toxina botulínica, nas consistências líquida e pastosa, considerando a relação entre a depuração faríngea e o movimento do osso hióide.

Tabela 4 - Comparação entre os grupos controle, pré e pós-aplicação, para a penetração, aspiração e escape na consistência líquida

Tabela 5 - Comparação entre os grupos controle, pré e pós-aplicação, para a penetração, aspiração e escape na consistência pastosa

Tabela 6 - Comparação entre os grupos controle, pré e pós-aplicação para os resíduos na consistência líquida

Tabela 7 - Comparação entre os grupos controle, pré e pós-aplicação para os resíduos na consistência pastosa

Tabela 8 - Comparações entre os grupos para o número de deglutições na consistência líquida

Tabela 9 - Comparações entre os grupos para o número de deglutições na consistência pastosa 
Tabela 10 - Comparação entre os grupos controle e pré-aplicação para as variáveis da anamnese fonoaudiológica

Tabela 11 - Comparação entre os grupos pré e pós-aplicação para as variáveis da anamnese fonoaudiológica.. 


\section{LISTA DE ABREVIATURAS}

BTX - Toxina Botulínica

BTX-A - Toxina Botulínica tipo A

EMG - Eletromiografia

EMGL - Eletromiografia Laríngea

ESE - Esfíncter Superior do Esôfago

HCFMRP-USP - Hospital das Clínicas da Faculdade de Medicina de Ribeirão Preto da Universidade de São Paulo

ms - Milissegundos

IC - Intervalo de Confiança

IMH - Início do Movimento do Hióide

IFF - Início da Fase Faríngea

TDPO - Tempo de Preparação Oral

TDF - Tempo de Depuração Faríngea

TTO - Tempo de Trânsito Oral

TTF - Tempo de Trânsito Faringeo

TTES - Tempo de Trânsito pelo Esfíncter Esofágico Superior

TMH - Tempo de Movimento do Hioide

TOFE - Tempo de Trânsito Orofaríngeo Esofágico 
1 INTRODUÇÃO

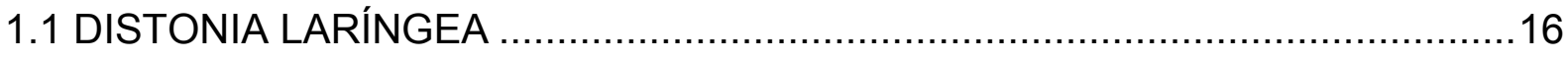

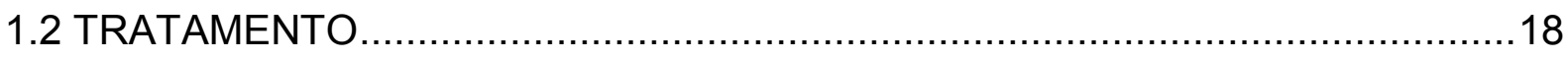

1.3 EFEITOS COLATERAIS DA TOXINA BOTULÍNICA ....................................22

2 JUSTIFICATIVA

2.1 OBJETIVO

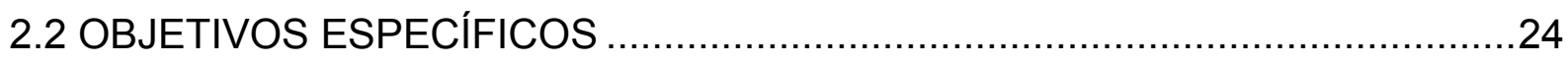

3 METODOLOGIA

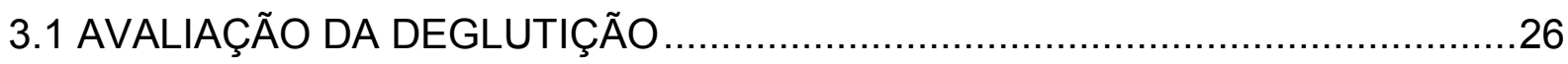

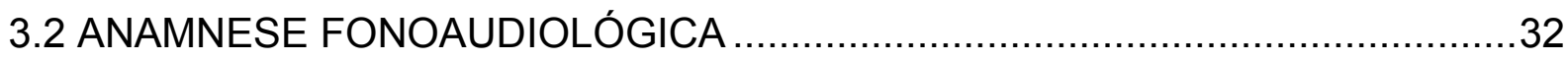

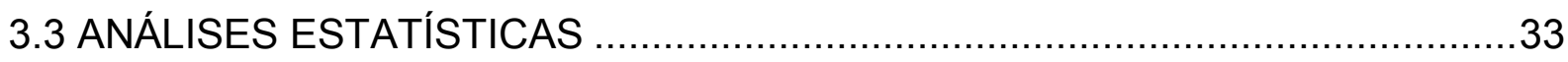

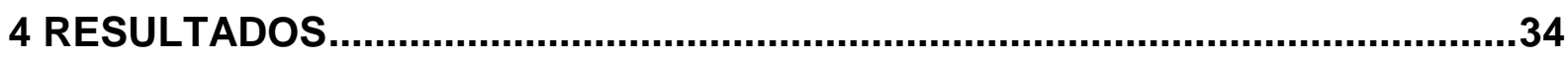

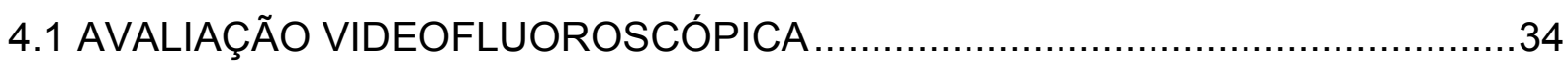

4.2 AVALIAÇÃO QUALITATIVA DA DEGLUTIÇÃO........................................... 40

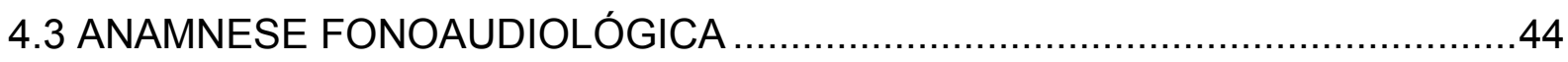

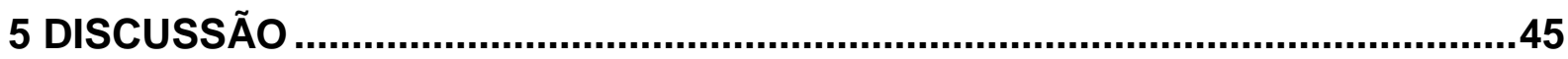

5.1 EFEITO DA DISTONIA LARÍNGEA NA DEGLUTIÇÃO …...............................46

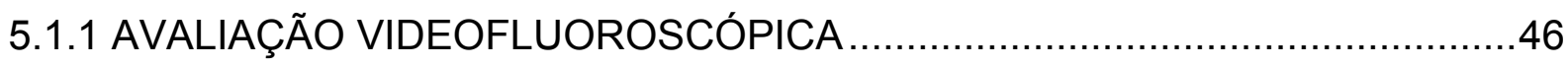

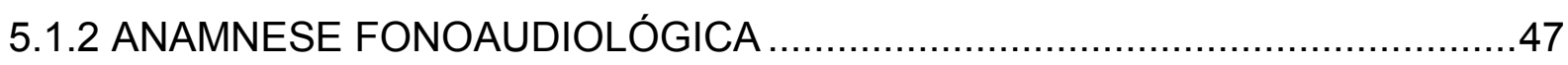

5.2 EFEITO DA TOXINA BOTULÍNICA NA DEGLUTIÇÃO...................................48

5.2.1 AVALIAÇÃO VIDEOFLUOROSCÓPICA E ANAMNESE FONOAUDIOLOGICA.48

6 CONCLUSÃO

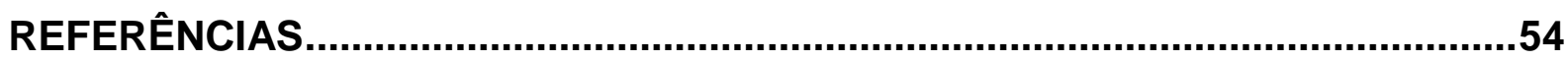

ANEXOS

Anexo A - Termo de Consentimento Livre e Esclarecido para os Pacientes ............61 
Anexo B - Termo de Consentimento Livre e Esclarecido para os Controles

.63

Anexo C - Carta de Aprovação do Comitê de Ética em Pesquisa do Hospital das Clínicas da Faculdade de Medicina de Ribeirão Preto ............................................65

Anexo D - Protocólo da Análise Videofluoroscópica Qualitativa...............................66

Anexo E - Protocólo da Análise Videofluoroscópica Quantitativa............................67

Anexo F - Protocólo da Anamnese Fonoaudiológica Pré-aplicação..........................68

Anexo G - Protocólo da Anamnese Fonoaudiológica Pós-aplicação .......................70

Anexo H - Quadro de Resultados Diagnósticos, Qualitativos e Queixas dos

Pacientes com Distonia Laríngea ........................................................... 72 


\section{INTRODUÇÃO}

\subsection{DISTONIA LARÍNGEA}

Distonia é um distúrbio do movimento, caracterizado por contrações musculares involuntárias sustentadas que levam a movimentos repetitivos e posturas de torção anormais nas áreas afetadas, de múltiplas ou simples (focal) regiões do corpo, incluindo a cabeça, o pescoço, a face, o tronco, os braços e as pernas (JIMENEZ-SHAHED, 2012).

A forma mais comum de distonia é a focal que está presente principalmente em adultos. Essa distonia pode afetar a laringe (disfonia espasmódica), causando uma voz com qualidade tensa e descontínua durante o fechamento involuntário das pregas vocais na fonação (DELONG; JUNCOS, 2005).

A distonia ocorre com mais frequência em mulheres do que em homens e varia de acordo com a etnia, sendo as alterações orais mais frequentes do que as faríngeas (ERTEKIN et al., 2002).

Estudo clínico, realizado no Brasil em 135 participantes com distonia, encontrou $54 \%$ com distonia focal, $17,8 \%$ segmentar, $8,1 \%$ hemidistonia, 1,5\% multifocal e $18,6 \%$ generalizada. A distonia secundária comprometia $26 \%$ dos participantes, e em 5,9\% havia história familiar (PEREIRA, 2010).

A distonia laríngea é um exemplo de um distúrbio focal, de ação induzida que afeta o controle motor da laringe. Pode ser classificada como primária ou secundária, que pode resultar de trauma, infecção, a medicação, ou desordem neuromuscular subjacente (HO et al., 2011), pode afetar frequentemente a produção da voz e a fala encadeada, apresentando efeitos debilitadores sobre a comunicação (BLITZER, 2010; CANNITO et al., 2008).

Existem duas formas de distonia, a adutora e a abdutora. A distonia laríngea adutora é um distúrbio de voz caracterizado por distensão do musculo laríngeo, quebra da voz nas vogais durante a fala devido à intermitente hiperadução das pregas vocais, resultando em uma qualidade de voz áspera, tensa-estrangulada, com quebras fonatórias, quebras de intensidade, frequência fundamental baixa e a produção de fala com esforço, e ocorre em aproximadamente $80 \%$ a $90 \%$ dos casos. A distonia laríngea abdutora é relativamente rara e envolve intermitentes 
faltas de voz durante as quebras vocais, caracterizada pelo aumento intermitente da glote, qualidade de voz soprosa transitória, pela incapacidade de pronunciar as consoantes antes da iniciação das vogais seguintes, e é geralmente considerada como um tipo de distonia laríngea central de ação induzida, e ocorre em aproximadamente $10 \%$ a $20 \%$ dos casos (CANNITO et al., 2008; LUDLOW, 2009; WATTS et al., 2008).

A distonia pode começar em qualquer idade. Nos quadros de distonia segmentar o pico do inicio encontra-se entre 45 e 60 anos, e nas distonias focais em torno dos 45 anos, sendo que os quadros de distonias focais laríngeas apresentam pico de início entre 35 e 50 anos (KORN et al., 2011).

Existem também os tipos mistos em que os sintomas dependem dos grupos musculares mais afetados. A distonia laríngea geralmente ocorre como uma distonia focal, mas pode aparecer em conjunto com distonias globais e deficiências neuromusculares, bem como com toxicidade de droga (STONG et al., 2005).

A fisiopatologia da distonia laríngea é desconhecida, atribuída à disfunção dos sistemas de retroalimentação laríngeos que desinibem a ação muscular laríngea. São encontradas lesões focais com perda de mielina na substância branca do trato corticobulbar, responsável pelo controle central da produção voluntária da voz (NÚÑEZ-BATALLA et al., 2011).

Acredita-se que a fisiopatologia da distonia envolve uma deficiência da inibição motora cortical, possivelmente resultante de uma disfunção no trabalho motor em rede associada a anormalidades no córtex sensório-motor, gânglios basais e cerebelo (JIMENEZ-SHAHED, 2012).

As distonias têm causa desconhecida, embora a maioria dos autores pense que os gânglios da base estejam envolvidos (BIASE et al., 2006). A causa da distonia laríngea, muitas vezes com distúrbios de voz, pode ser o nervosismo e a laringite de refluxo. $O$ aparecimento da distonia vocal ocorre lentamente ao longo de um período de vários meses a um ano, e dois terços dos doentes afetados são mulheres em torno dos 40 anos. Distonia laríngea e tremor de laringe são frequentemente confundidos (SCHLOTTHAUER et al., 2008; WATTS et al., 2008).

O entendimento da etiologia da distonia laríngea tem evoluído ao longo do tempo a partir de teorias de causas psicológicas subjacentes a opinião atual, que enfatiza a causa neurológica primária (WATTS et al., 2008). Alguns autores 
associam esses distúrbios a doenças psicológicas, neurológicas ou traumáticas (SCHWEINFURTH et al., 2002; JIMENEZ-SHAHED, 2012).

O diagnóstico das diferentes distonias é realizado pelos exames: geral, otorrinolaringológico, neurológico, sendo confirmado através da videolaringoestroboscopia (SANTOS et al., 2006).

O exame oftalmológico incluindo a lâmpada de fenda, a eletroneuromiografia com velocidade de condução, os potenciais evocados somatossensitivos, o eletroretinograma e a tomografia computadorizada e/ou a ressonância magnética de crânio, podem ser úteis no diagnóstico das distonias. Estes últimos exames permitem avaliar lesões nos gânglios da base em alguns casos de distonia generalizada, focal ou hemidistonia (GEYER, 2006; ALBANESE, 2007).

O diagnóstico de distonia laríngea é baseado em sinais clínicos: avaliação perceptivo-auditiva da voz e nasofibrolaringoscopia. As provas diagnósticas, como emissão de sons graves e agudos, frases com predomínio de fonemas surdos ou sonoros, dentre outras, auxiliam no diagnóstico diferencial da distonia laríngea (BIASE et al., 2006).

\subsection{TRATAMENTO}

O ideal para as distonias seria uma terapêutica que eliminasse a causa. Entretanto, como na maioria das vezes isto não é possível, podem-se relacionar três abordagens principais para o tratamento sintomático das distonias: o farmacológico, o não farmacológico e o cirúrgico (PEREIRA, 2010).

A distonia laríngea é uma desordem crônica. Seu tratamento pode ser através da farmacoterapia, com drogas anticolinérgicas, com a injeção de toxina botulínica (BTX) no grupo de músculos afetados, e com método cirúrgico, com rizotomia anterior cervical associada com injeção da BTX (DELONG; JUNCOS, 2005). Já as desordens funcionais da voz podem responder às terapias médicas ou comportamentais. A disfonia funcional pode envolver fatores psicológicos e ser efetivamente tratada apenas por terapia da voz, enquanto que a cirurgia é aplicada para o tratamento das desordens crônicas estáveis (LUDLOW, 2009).

As técnicas cirúrgicas de desnervação de corda vocal, avulsão/ressecção do nervo laríngeo superior, e estreitamento do músculo tireoaritenóide já foram abandonadas, optando-se atualmente pelo tratamento com a toxina botulínica, que é 
geralmente considerado como o principal tratamento farmacológico para a distonia laríngea de adução, e pode também ser benéfica em casos de distonia laríngea abdutora ou distonia laríngea mista (ROSAS; SÁ, 2007; WATTS et al., 2006).

A terapia com o uso da toxina botulínica provou ser altamente eficaz para as perturbações da fala, consequentes das contrações distônicas das pregas vocais, com uma melhoria estabelecida em 80 a 100\% dos pacientes (SVETEL et al., 2007).

A toxina botulínica tem sido usada desde a década de 80 . No Brasil tem sido usada desde 1991. Em 2000 o FDA aprova Botox® Cosmetics, para o tratamento de linhas faciais hipercinéticas e a toxina $B$, para a distonia. Comercialmente a toxina botulínica do tipo $A(B T X-A)$ está disponível como Botox® e Dysport (ELMIYEH, 2010; JANKOVIC, 2004a; QUAGLIATO, 2010).

A toxina botulínica tipo $A(B T X-A)$ é amplamente utilizada em terapias neurológicas para variadas indicações como distonia focal, espasticidade, espasmo hemifacial, hiperidrose, e excesso de saliva. Mas é contra-indicada para indivíduos com hipersensibilidade conhecida a qualquer dos componentes da formulação, quando existem perturbações da transmissão neuromuscular (como miastenia graves),quando os antibióticos aminoglicosídicos ou estreptomicina já são utilizados ou são susceptíveis de ser utilizados, quando há doenças hemorrágicas de qualquer tipo, quando o paciente utiliza terapia anticoagulante, em qualquer situação na qual deva ser evitada injeções intramusculares, e durante a gravidez (GIOLTZOGLOU et al., 2005).

A eletromiografia (EMG) é um exame que avalia o comportamento elétrico e a integridade da unidade motora: o motoneurônio inferior, seu axônio, a placa mioneural e fibra muscular, e pode ter função auxiliar terapêutica, como na orientação da aplicação de toxina botulínica (ZARZUR; SHINZATO, 2007).

Uma vez injetada no músculo, a BTX-A, atinge o terminal nervoso colinérgico através da associação das propriedades de dispersão e difusão. Mas para que isso aconteça se requer uma molécula dessa toxina com as duas cadeias (leve/pesada) intactas, estabelecida como uma endopeptidase zinco dependente, que quebra especificamente as proteínas essenciais para a mediação da exocitose do neurotransmissor, a acetilcolina. Com a chegada da toxina, inicia-se seu mecanismo de ação que se faz em três etapas: a) Ligação ao Terminal Nervoso Colinérgico - A BTX-A, se liga a um receptor de alta afinidade encontrado nos neurônios colinérgicos dos nervos motores, através do domínio de ligação da cadeia pesada; 
b) Internalização/Translocação - Após a BTX-A se ligar a célula neuronal, inicia-se o processo de internalização, intermediado por receptores de endocitose, que se localizam na porção amielínica da junção neuromuscular de mamíferos; c) Inibição Cálcio-Dependente da Liberação (exocitose) do Neurotransmissor - A inibição da exocitose do neurotransmissor, acetilcolina, acontece através de uma atividade proteolítica zinco dependente da cadeia leve, que quebra seletivamente as ligações peptídicas de uma proteína SNARE (soluble n-ethylmaleimidesensitive factor attachment protein-receptor) essencial para a liberação do neurotransmissor que é cálcio dependente. Assim, a cadeia leve exerce seu efeito quebrando as proteínas que são responsáveis pela fusão das vesículas de acetilcolina com a membrana celular do terminal nervoso (SPOSITO, 2009).

A aplicação subcutânea, periódica de toxina botulínica é uma opção terapêutica nas distonias focais. A BTX bloqueia a liberação a nível pré-sináptico da acetilcolina na placa motora, provocando desnervação química nos terminais nervosos dos neurônios motores gama e afeta a função autonômica dos gânglios e neurônios pós-ganglionares parassimpáticos e simpáticos colinérgicos (ROSAS; SÁ, 2007).

Existem benefícios da injeção de toxina botulínica no músculo cricofaríngeo para controlar os sintomas de disfagia em pacientes adequadamente selecionados. Estas injeções são um método seguro e efetivo de tratamento para certas formas de disfagia. Enquanto algumas melhoras podem ser vistas em pacientes com doenças neuromusculares significantes, os melhores resultados podem ser apreciados nos pacientes com disfunção vocal associada com tremores do músculo cricofaríngeo (GARY et al., 2000).

$\mathrm{Na}$ distonia laríngea, a toxina botulínica é administrada de forma unilateral (injetada no músculo da prega vocal esquerda ou direita) ou bilateralmente (injetada nos músculos de ambos os lados das pregas vocais), com menores níveis de dosagem relatados nas injeções bilaterais. Existem também diferentes técnicas de injeção que podem ser utilizadas, incluindo a técnica guiada pela eletromiografia percutânea, e a técnica guiada pela videonasolaringoscopia (WATTS, 2006).

O músculo cricofaríngeo é distinto da proximidade dos músculos da faringe pela maior quantidade de tecido elástico e contrações tônicas que são brevemente interrompidas por peristalses primárias da deglutição e durante o vômito e 
eructação. Algumas desordens podem afetar o músculo cricofaríngeo e causar disfagia (GARY et al., 2000).

O envelhecimento da laringe é caracterizado por mudanças involuntárias que alteram sua característica biomecânica e neural e criam um ambiente biológico que é diferente da característica biomecânica e neural jovem. A distonia laríngea adutora é tipicamente tratada usando injeções de toxina botulínica nas pregas vocais para manter os espasmos musculares adutores reprimidos, que são rompidos para a produção da fala e voz (CANNITO et al., 2008).

O potencial de ação da eletromiografia resulta de uma rápida e transitória mudança na permeabilidade da membrana celular, difundida por toda a fibra muscular. Na fibra muscular, ele se inicia com a chegada de impulsos nervosos ao nível da junção neuromuscular. Estes impulsos nervosos são propagados ao longo da unidade motora que é a unidade funcional do sistema nervoso periférico, sendo constituídos pelo corpo celular, seus prolongamentos, pela junção neuromuscular e por todas as fibras musculares inervadas por este neurônio (DUMITRU; GITTER, 2002; SATALOFF et al., 2006).

Tanto o tremor de voz, como a distonia laríngea e outras desordens, podem responder ao tratamento pela injeção de TBX-A (ADLER et al., 2004).

$A$ injeção bilateral de pequenas quantidades de toxina botulínica dentro dos músculos adutores (tiroaritenóideos) demonstrou ser efetiva no tratamento da distonia laríngea adutora. Dentro de poucas semanas da injeção, ocorre à inervação de novas fibras. Entretanto, muitos desses novos crescimentos não sobrevivem e a reinervação no final da placa original que se inicia em cerca de dois meses e os sintomas retornam gradualmente, completamente após 4-5 meses. Embora a desnervação bilateral parcial do tiroaritenóide com a toxina botulínica seja benéfica em mais de $90 \%$ dos pacientes com as distonias laríngeas adutoras, algumas mudanças no distúrbio do sistema nervoso central podem contribuir na redução dos sintomas como espasmos, que são reduzidos nos músculos não tratados nos pacientes com distonia laríngea adutora (LUDLOW, 2009).

A toxina botulínica necessita de esquemas diferentes de tratamento e padrões de dosagem para se ajustar aos diversos pacientes, mas a significante melhora da função pode ser alcançada em quase todos eles (BLITZER, 2010).

Em estudo de 155 pacientes (idade média 50,6 nos homens e 54,4 nas mulheres), submetidos à injeção da Toxina Botulínica no músculo tireoaritenóideo, 
para tratamento da distonia laríngea adutora, foi possível observar que a dose e a duração do efeito benéfico da toxina botulínica no tratamento não variaram com a idade ou sexo (VASCONCELOS, 2009).

\subsection{EFEITOS COLATERAIS DA TOXINA BOTULÍNICA}

Os efeitos colaterais vocais são geralmente relacionados à dose da toxina botulínica utilizada e envolve um período de voz "soprosa", disfagia leve, moderada ou grave e, ocasionalmente, sintomas semelhantes ao de pacientes com virose respiratória, como a gripe, devido a reações sistêmicas idiossincráticas à toxina botulínica. (WATTS et al., 2006).

Estudo demonstrou que a complicação mais comum do tratamento, com a aplicação da toxina botulínica é a disfagia, encontrada em $14 \%$ de todos os participantes, sendo que em alguns sujeitos este sintoma era grave, ao ponto de requerer mudanças para uma dieta leve ou líquida (JANKOVIC, 2004b).

Vários estudos têm mostrado que a toxina botulínica tem sido tão segura e efetiva para a distonia cervical como para a hiperhidrose palmar, dobras glabelares, e dobras dos cantos dos olhos. Os efeitos adversos mais comuns para estes tratamentos são a disfagia e a xerostomia (DUBOW et al., 2005).

A disfagia era frequentemente mais relatada pelo uso de injeções bilaterais nos músculos esternocleidomastóideos. Um estudo mostrou que dosagens iguais ou acima de 20 unidades de toxina administradas no músculo esternocleidomastóideo eliminam completamente a atividade muscular e podem produzir fraqueza no pescoço e disfagia (JANKOVIC, 2004b).

As injeções de toxina botulínica são consideradas o tratamento sintomático de opção na distonia cervical devido a uma alta razão de resposta e baixa incidência de efeitos colaterais. $O$ tratamento com a toxina botulínica atinge os músculos flexores cervicais superficialmente (esternocleidomastóideo e escaleno anterior), que às vezes resultam em disfagia. Após duas das dez injeções, todos os participantes deste estudo referiram dificuldades para deglutir (GLASS et al., 2009).

O principal efeito adverso do tratamento com injeções de toxina botulínica para o tremor vocal era quebra da respiração e a disfagia. Na segunda semana, os pacientes apresentavam alterações respiratórias e na terceira semana os pacientes apresentavam disfagia (ADLER et al., 2004). 
As contrações musculares irregulares e espasmódicas durante a fala e atividades diárias estão associadas com a sensação de esforço excessivo para dominar os espasmos. Espasmos excessivos podem acontecer durante o teste da função pulmonar (BRAUN et al., 1995).

Em estudo com pacientes com distonias cervicais submetidos ao tratamento da BTX-A, observou-se que a gravidade das alterações motoras cervicais foi maior entre os pacientes com distonia generalizada do que nos pacientes com distonia focal, houve acentuada melhora dos sintomas motores e da dor da distonia cervical com a aplicação de BTX-A e a disfagia ocorreu em 2,35\% dos pacientes (CAMARGO et al., 2008).

Em estudo retrospectivo de 10 casos com diagnóstico de disfonia espasmódica, quanto a sintomas e desordens neurológicas associadas, verificou-se que $87,5 \%$ dos pacientes tinham diagnóstico de distúrbios do movimento feito por neurologista, entre eles $50 \%$ com distonias orofaciais, $50 \%$ com tremor essencial e $12 \%$ com paraparesia espástica. Portanto, a presença de desordens do movimento acompanhou quase que a totalidade os casos de disfonia espasmódica (COELHO et al., 2010). 


\section{JUSTIFICATIVA}

A aplicação da toxina botulínica pode alterar a deglutição, e esse seria efeito colateral indesejável da droga no tratamento dos pacientes com distonia laríngea.

\subsection{OBJETIVO}

O objetivo deste trabalho foi avaliar a deglutição de pacientes com distonia laríngea, antes e após o tratamento com a toxina botulínica.

\subsection{OBJETIVOS ESPECÍFICOS}

Quanto às variáveis quantitativas, (tempo de preparação oral, tempo de trânsito oral, tempo de trânsito faríngeo, tempo de depuração faríngea, tempo de duração do trânsito no esfíncter superior do esôfago, tempo de duração do movimento do osso hióide, tempo entre a chegada do bolo na faringe e o inicio do movimento do hióide, tempo de trânsito orofaríngeo, relação entre a depuração faríngea e o tempo de movimento do hióide) os objetivos foram:

- Comparar os grupos controle e com distonia laríngea, em relação às variáveis de deglutição.

- Comparar os pacientes com distonia laríngea antes e depois do tratamento com toxina botulínica, em relação às variáveis de deglutição.

Quanto às variáveis qualitativas (penetração, aspiração, resíduos, escape, número de deglutições) os objetivos foram:

- Verificar o efeito de intervenção da aplicação da toxina botulínica nas variáveis qualitativas.

- Comparar as variáveis qualitativas entre os grupos controle, pré e pós-tratamento com a toxina botulínica. 


\section{METODOLOGIA}

Foram avaliados 20 indivíduos e destes 3 foram excluídos, 1 por não apresentar diagnóstico de distonia laríngea, 1 por ter realizado somente a avaliação pré-aplicação da BTX e 1 por ter realizado apenas a avaliação pós-aplicação da BTX. Portanto, chegou-se ao total de 17 indivíduos adultos, sendo 12 mulheres e 5 homens, entre 23 e 88 anos de idade (média 58,1anos), com diagnóstico clínico de distonia laríngea e indicação de tratamento com toxina botulínica do tipo $\mathrm{A}$, realizado no Ambulatório de Laringe e Voz do Departamento de Oftalmologia, Otorrinolaringologia e Cirurgia de Cabeça e Pescoço, antes e após o tratamento da distonia com o uso de Toxina Botulínica do tipo A, e 20 indivíduos adultos saudáveis, como controles, sendo 15 mulheres e 5 homens, entre 32 e 82 anos (média 53,1 anos), que eram acompanhantes dos pacientes atendidos no Hospital das Clínicas de Ribeirão Preto. Não houve diferença na média de idade entre os dois grupos $(P=0,37)$.

Inicialmente os participantes preencheram um termo de consentimento livre esclarecido para a realização deste estudo (Anexos A e B), que foi aprovado pela Comissão de Normas Éticas e Regulamentares do Hospital das Clínicas da FMRPUSP, com processo de número 13687/2009 (Anexo- C).

Foram incluídos neste estudo indivíduos que apresentaram diagnóstico de distonia laríngea com ou sem componente de tremor associado, realizado pelo setor de Cirurgia de Cabeça e Pescoço do HCFMRP-USP, que nunca receberam tratamento com toxina botulínica ou que já receberam esse tratamento pela ultima vez há mais de quatro meses, não havendo indícios clínicos de que existisse efeito residual da mesma no músculo tireoaritenóideo. O critério utilizado para a realização do diagnóstico desses pacientes foi através da avaliação clínica neurológica e otorrinolaringológica, pela avaliação nasofibroscópica e fonoaudiológica.

Foram excluídos deste trabalho os indivíduos menores de 18 anos, e que tinham histórico de cirurgias prévias na laringe, disfonia pregressa, distúrbios de linguagem e/ou auditivos.

A aplicação da toxina botulínica foi realizada por meio da introdução de agulha através da membrana cricotireóidea a $0,5 \mathrm{~cm}$ da linha sagital mediana, 
angulada de $30^{\circ}$ a $45^{\circ}$ lateral e superiormente até a localização do músculo tireoaritenóideo, guiado por eletromiografia.

A eletromiografia de laringe foi realizada na Unidade de Neurofisiologia Clínica, do Hospital das Clínicas da Faculdade de Medicina de Ribeirão Preto da Universidade de São Paulo, HCFMRP- USP, sempre pelo mesmo neurologista, com experiência em eletromiografia, acompanhado pelo mesmo cirurgião de cabeça e pescoço, com treinamento prévio para realização de eletromiografia de laringe.

O paciente era colocado em decúbito dorsal, com a cabeça e o pescoço levemente estendidos. A anti-sepsia da pele do pescoço foi feita com álcool etílico a $70 \%$.

A atividade elétrica foi filtrada e conectada a um eletromiógrafo, para ser analisada. Os registros obtidos foram armazenados em equipamento Nihon Kohden $\circledast$, modelo Neuropack 8, com filtro de banda passante entre $5 \mathrm{~Hz}$ e $10 \mathrm{KHz}$, base de tempo de $10 \mathrm{~ms} /$ div e sensibilidade variando de 50 a $200 \mu \mathrm{V}$.

A aplicação da toxina botulínica (Dysport) do laboratório Alergan, foi feita unilateralmente e/ou bilateralmente e as doses utilizadas foram definidas para cada indivíduo, e variaram de 5 a 20 unidades, de acordo com a necessidade.

\subsection{AVALIAÇÃO DA DEGLUTIÇÃO}

Os participantes do estudo foram submetidos a uma anamnese fonoaudiológica, avaliação instrumental e objetiva da deglutição, a videofluoroscopia, antes da injeção e 30 dias após a injeção da toxina botulínica, no dia de retorno do paciente para avaliação ambulatorial do tratamento. A videofluoroscopia teve a duração de aproximadamente 1minuto. Este exame foi realizado no setor de Radiologia do HCFMRP-USP.

O equipamento utilizado para a realização do exame foi o Angiógrafo Arcomax, da marca Philips, modelo BV 300 (Veenpluis, The Netherland). As imagens foram gravadas em 30 quadros por segundo (Figura 1).

O exame foi realizado com a captação da imagem em incidência látero-lateral direita, com o sujeito posicionado verticalmente (ângulo próximo a 90 ), sentado em uma cadeira (Figura 2). 
Durante a realização do exame, foram avaliadas seis ofertas de $5 \mathrm{ml}$ cada uma, sendo 3 na consistência líquida e 3 na consistência pastosa. A ordem das ofertas foi aleatória, sendo o procedimento randomizado.

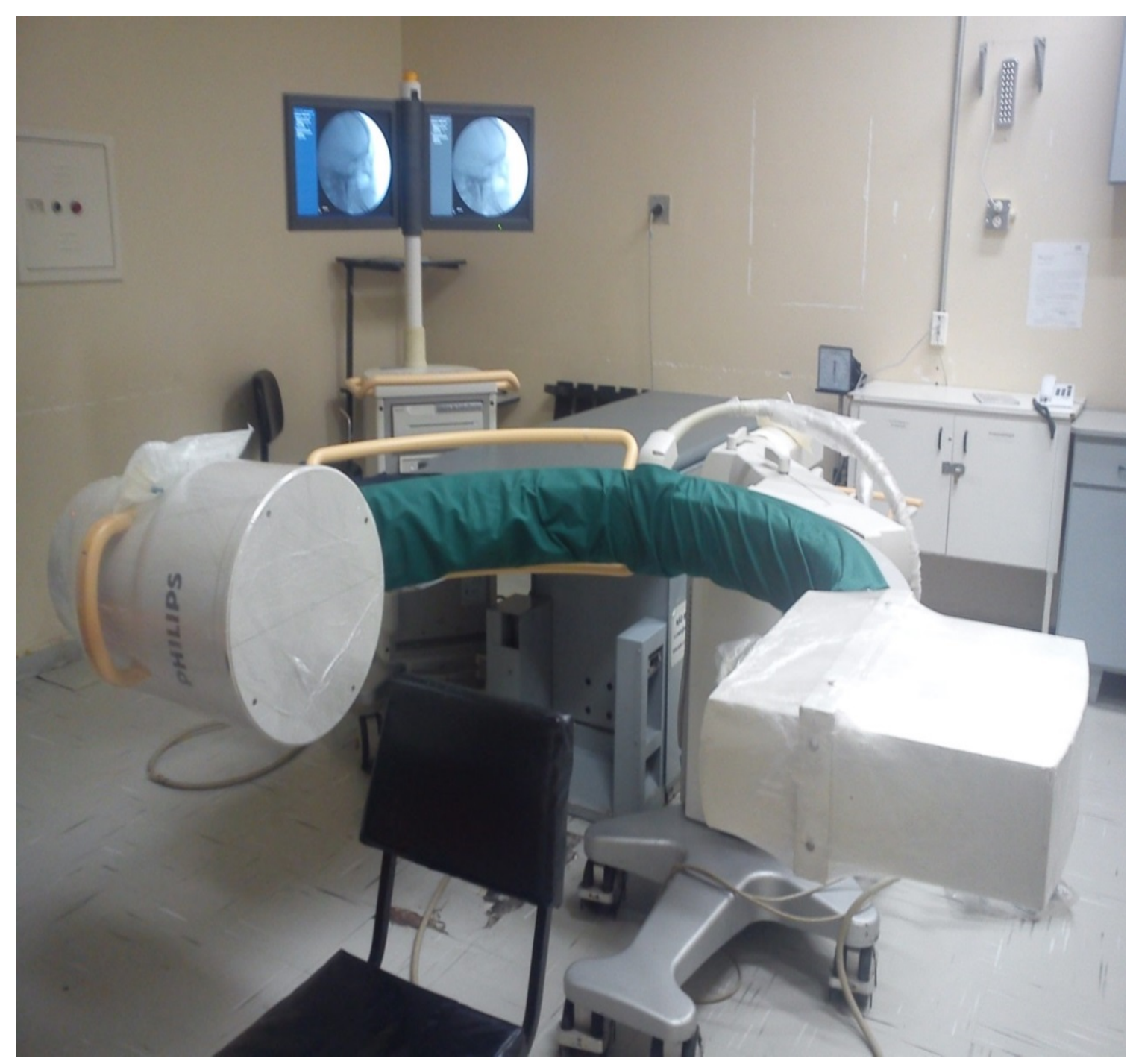

Figura 1 - Aparelho videofluoroscópico utilizado para avaliação da deglutição nos participantes do estudo. 


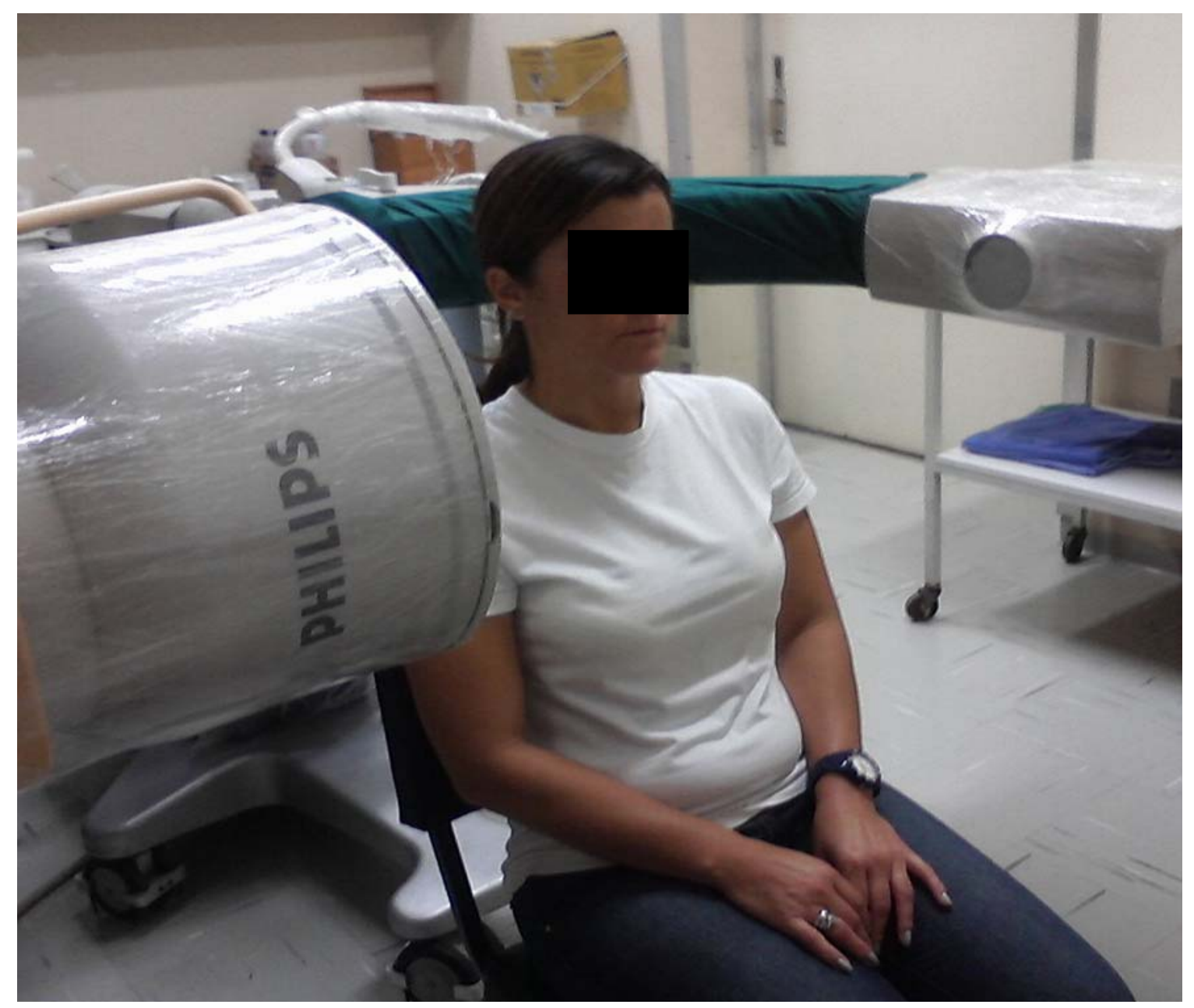

Figura 2 - Imagem da posição de uma voluntária durante a realização do exame videofluoroscópico da deglutição.

Para a avaliação da consistência líquida, foi oferecido contraste radiológico, sulfato de bário (Bariogel® 100\%, Laboratório Cristália, Itapira, São Paulo), com o auxílio de uma seringa, que foi posicionada com a ponta direcionada para a porção inferior e anterior da cavidade oral dos participantes. Durante a avaliação da consistência pastosa, obtida com a adição de $2,4 \mathrm{~g}$ do espessante de alimentos ThickenUp Clear (Nestlé Brasil Ltda. São Bernardo do Campo-SP) em $50 \mathrm{~mL}$ de sulfato de bário líquido, e oferecidas em uma colher posicionada na boca dos participantes (Figura 3). 


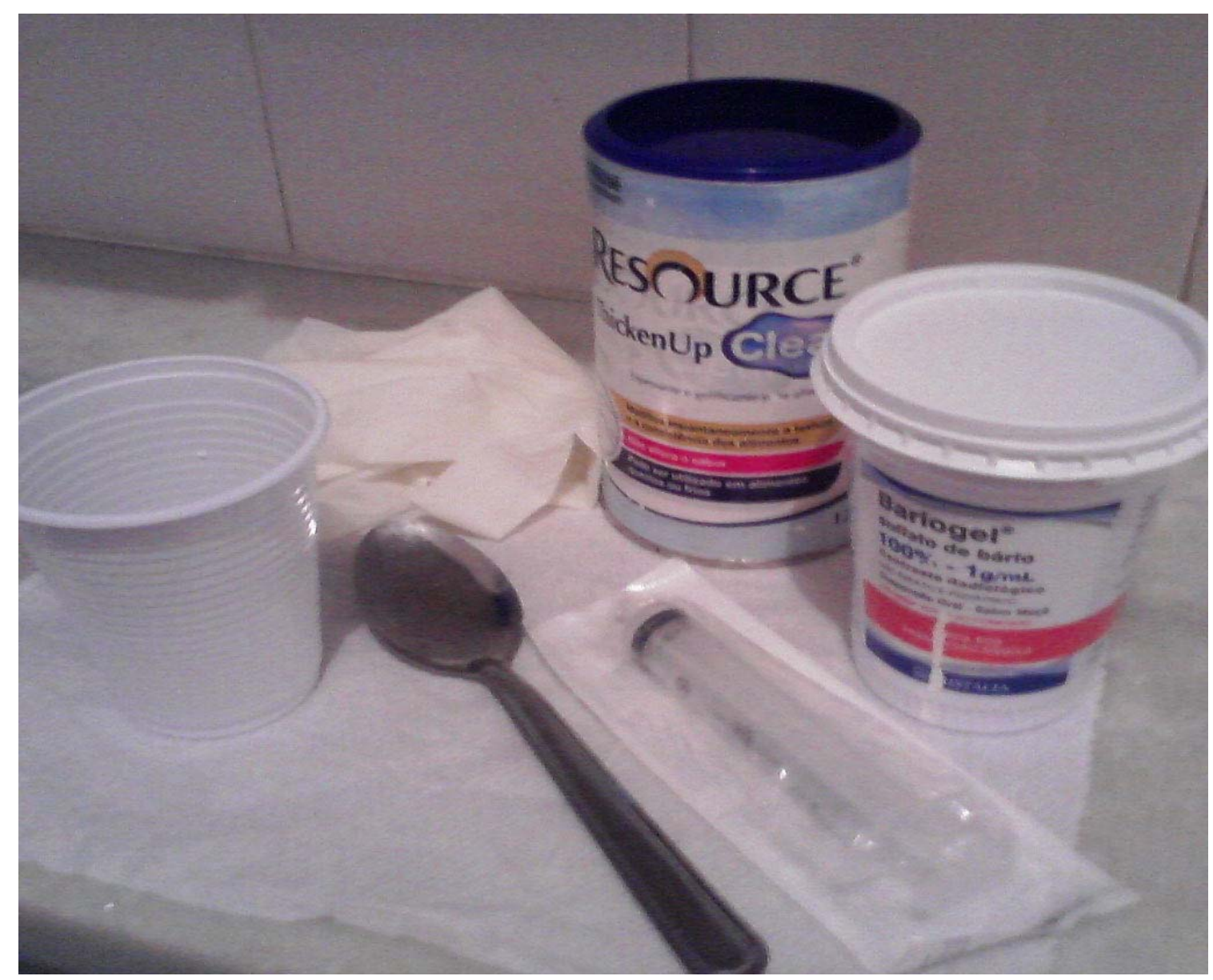

Figura 3 - Materiais utilizados durante a realização do exame videofluoroscópico nos participantes do estudo.

Foram analisadas em tempo real e quadro a quadro (com 30 quadros por segundo) todas as deglutições realizadas, a fim de se estudar as fases oral e faríngea. Cada fase da deglutição teve os tempos dos trânsitos medidos através do uso de um software desenvolvido por pós-graduandos do Departamento de Neurologia e Psiquiatria da Unesp de Botucatu e Departamento de Engenharia Elétrica de São Carlos (SPADOTTO et al., 2008). O software possibilitou o registro do tempo em milisegundos, através da análise dos quadros de vídeo e da seriação da deglutição. A análise foi realizada de maneira quantitativa, quadro a quadro, onde se marcou o início e o término do trajeto do bolo, obtendo-se assim o tempo de duração da fase através da contagem dos quadros.

Durante a avaliação da fase oral, foram observados os aspectos funcionais de contato de língua no palato duro, movimento da base da língua, controle oral (por meio do escape anterior e posterior para a faringe) e resíduo oral após deglutição. 
$\mathrm{Na}$ avaliação da fase faríngea da deglutição, foram verificados: o trânsito faríngeo, penetração em nasofaringe, excursão do osso hióide, sobra de resíduos em valécula e recessos piriformes, penetração e aspiração laríngea (Anexos D e E).

Tanto a fase oral quanto a fase faríngea, foram medidas em milisegundos, onde foram analisados:

Inicio da preparação oral: Fechamento dos lábios após o bolo ser posicionado na boca.

Inicio da fase oral: Com a ponta da língua na região retroincisal para iniciar a ejeção do bolo.

Fim da fase oral: Passagem da cauda do bolo pelo ramo mandibular.

Início do movimento do osso hióide: Momento em que o osso hióide inicia o movimento de elevação durante a deglutição.

Fim do movimento do osso hióide: Término do movimento de descida do osso hióide.

Entrada na faringe: Entrada do bolo na faringe coincidindo com o ramo da mandíbula.

Abertura do esfíncter superior do esôfago: Entrada da cabeça do bolo no esfíncter.

Fechamento do esfíncter superior do esôfago: Fim da passagem da cauda do bolo pelo esfíncter, finalizando a deglutição orofaríngea.

Penetração: Permanência do alimento na região supraglótica.

Aspiração: Alimento visualizado na laringe, abaixo das pregas vocais ou na traqueia. 
Resíduos: Permanência do bário nas seguintes regiões: oral, valécula e seios piriformes, considerando a primeira deglutição.

Escape: Perda do bolo da fase oral para a orofaríngea, antes do desencadeamento do reflexo da deglutição.

Número de Deglutições: Quantidade de deglutições para eliminação do bolo na cavidade oral do participante.

A análise das variáveis citadas acima foi feita considerando o intervalo de tempo entre o início e o fim do movimento das estruturas:

Tempo de preparação oral (TDPO): Fechamento dos lábios e posicionamento da ponta da língua na região retroincisal.

Tempo de trânsito oral (TTO): Posicionamento da ponta da língua na região retroincisal e passagem da cauda do bolo pelo ramo mandibular.

Tempo de trânsito faríngeo (TTF): Intervalo de tempo entre a passagem da cauda do bolo pelo ramo mandibular e o fim da passagem do bolo pelo esfíncter superior do esôfago (ESE).

Tempo de depuração faríngea (TDF): Intervalo de tempo entre a entrada do bolo na faringe, coincidindo com o ramo da mandíbula, e o fim da passagem do bolo pelo esfíncter superior do esôfago.

Tempo de duração do trânsito no esfíncter superior do esôfago (TTESE): Intervalo de tempo entre a entrada do bolo no esfíncter superior do esôfago e o fim da sua passagem.

Tempo de duração do movimento do osso hióide (TMH): Intervalo de tempo entre o início e o fim do movimento do osso hióide. 
Tempo entre a chegada do bolo na faringe e o inicio do movimento do hióide (IFF - IMH): Intervalo entre a chegada do bolo na faringe e o inicio do movimento do hióide.

Tempo de trânsito orofaríngeo (TOFE): Intervalo entre o início da fase oral até o momento em que ocorreu a passagem da cauda do bolo pelo esfíncter superior do esôfago (ESE).

Relação entre a depuração faríngea e o tempo de movimento do hióide (TDF/TMH): Proporção entre a duração da depuração faríngea e a duração do movimento do hióide.

\subsection{ANAMNESE FONOAUDIOLÓGICA}

Os participantes do estudo foram submetidos a uma avaliação de sua história clínica, realizada pela pesquisadora, através de uma anamnese, com questões apresentadas oralmente, antes e 30 dias após a aplicação da toxina botulínica. A avaliação teve a duração de aproximadamente 10 minutos, e foi realizada no setor de Radiologia do HCFMRP-USP, antes da realização do exame videofluoroscópico (Anexos F e G).

Para a realização dessa avaliação foram coletados inicialmente os dados de identificação do paciente, como nome, idade, data de nascimento, sexo, profissão, escolaridade, data, horário e possível diagnóstico.

Posteriormente, através do uso de questões fechadas, a pesquisadora fez as seguintes perguntas aos participantes: O senhor(a) fuma? Caso a resposta fosse positiva a avaliadora questionaria: Por quanto tempo?

A ingestão e a frequência do uso de bebidas alcoólicas foram realizadas com as perguntas: O senhor(a) costuma beber/tomar bebidas alcoólicas? Se a resposta fosse afirmativa era questionado: Quantas vezes por mês?

Quanto à queixa e a frequência de disfagia, realizada com as questões: $O$ senhor(a) tem dificuldade para se alimentar? Caso a resposta fosse afirmativa era interrogado: O senhor(a) tem mais dificuldade com alimentos líquidos, pastosos ou sólidos? E também era questionado se costuma tossir ou engasgar quando come? E quantas vezes isso ocorreu no ultimo mês? 


\subsection{ANÁLISES ESTATÍSTICAS}

As análises estatísticas foram feitas pelo escritório Proestat-Consultoria Estatística e Pesquisa de Mercado de Ribeirão Preto, que realizou inicialmente uma análise exploratória dos dados. Esta metodologia teve como objetivo básico sintetizar uma série de valores de mesma natureza, permitindo que se tivesse uma visão global da variação desses valores, organizando e descrevendo os dados de duas maneiras: por meio de tabelas com medidas descritivas e de gráficos.

Inicialmente foi realizada uma análise descritiva dos dados. Para verificar a associação entre as variáveis qualitativas (penetração, aspiração, resíduos, escape, número de deglutições) foi proposto o teste exato de Fisher.

Para verificar o efeito da intervenção foi proposto o teste de McNemar. Este teste verificou se existiam evidências de efeito de tratamento, ou seja, testou a hipótese de que a mudança de proporções entre os tempos é devido ao acaso ou, quando rejeitamos esta hipótese, podemos dizer que existe evidências de efeito de tratamento. Para os casos onde se obtiveram respostas com mais de dois níveis, se usou uma extensão do teste de McNemar.

Para as comparações foi proposto o modelo de regressão linear com efeitos mistos (efeitos aleatórios e fixos). Os modelos lineares de efeitos mistos foram utilizados na análise de dados em que as respostas estiverem agrupadas (mais de uma medida para um mesmo indivíduo) e a suposição de independência entre as observações num mesmo grupo não foi adequada. Esses modelos têm como pressuposto que seus resíduos tem distribuição normal com média 0 e variância $\sigma^{2}$ constante. Nas situações em que tal pressuposto não foi observado, transformações na variável resposta foram utilizadas. Para as comparações foi utilizado o pós-teste por contrastes ortogonais. As análises dos dados foram realizadas com o auxílio do software $S A S \circledR 9.0$, utilizando a PROC MEANS e a PROC FREQ. Os resultados são apresentados como mediana e intervalo de confiança (IC) $95 \%$. As diferenças foram consideradas significantes quando $p \leq 0.05$. 


\section{RESULTADOS}

\subsection{AVALIAÇÃO VIDEOFLUOROSCÓPICA}

$\mathrm{Na}$ comparação entre os grupos controle e pré-aplicação, para as consistências líquida e pastosa, quanto às variáveis de tempo para preparação oral do bolo, trânsito oral, trânsito faringeo, depuração faríngea, duração do trânsito no esfíncter esofágico superior, duração do movimento do osso hióide, trânsito orofaríngeo e a relação entre a duração da depuração faríngea e a duração do movimento do osso hióide, foi observado que a média do grupo pré-aplicação para o tempo de trânsito faringeo foi menor do que o grupo controle, para ambas as consistências, demonstrando respectivamente o valor de $p<0,01$ e $p=0,03$. Para a consistência pastosa, na comparação entre os grupos controle e pré-aplicação, para os tempos de trânsito oral e tempo do movimento do osso hióide, verificou-se que a média do grupo pré-aplicação, para ambos os tempos, foi maior do que no grupo controle, demonstrando respectivamente os valores de $p=0,03$ e $p=0,02$ (Tabelas 1 e 2).

Comparando-se o grupo controle com o pós-aplicação, para as consistências líquida e pastosa, nos tempos de preparação oral do bolo, trânsito oral, trânsito faringeo, depuração faríngea, duração no esfíncter esofágico superior, duração do movimento do osso hióide e trânsito orofaríngeo, verificou-se que o trânsito faringeo, para ambas as consistências, e a duração do trânsito pelo esfíncter superior do esôfago (ESE), para a consistência líquida, apresentaram uma média menor para o grupo pós-aplicação em relação ao controle, indicando respectivamente os valores de $p<0,01$ e $p=0,02$ (Tabelas 1 e 2).

$\mathrm{Na}$ comparação entre os grupos pré-aplicação e pós-aplicação, para a consistência líquida, nos tempos de trânsito da preparação oral do bolo, do trânsito oral, trânsito faringeo, depuração faríngea, duração no esfíncter esofágico superior, duração do movimento do osso hióide e do trânsito orofaríngeo (Tabela1), constatamos que nenhum destes trânsitos apresentou diferença significativa. Já na comparação entre os grupos, para a consistência pastosa, dos tempos já mencionados (Tabela 2), observamos que a média do tempo do trânsito faringeo 
para o grupo pré-aplicação foi maior do que para o pós-aplicação, nos indicando o valor de $p=0,05$.

Quando comparados os grupos controle, pré e pós-aplicação, em relação ao intervalo entre o tempo de início da fase faríngea e o tempo de inicio do movimento do osso hióide (Tabela 1), verificamos que o intervalo de tempo foi maior entre os pacientes do grupo pós-aplicação comparados com os do grupo controle $(p=0,05)$, para a consistência líquida, o que significa que a resposta do movimento do hióide foi mais tardia nos pacientes após aplicação do que nos controles. Para a consistência pastosa, quanto ao intervalo entre o inicio da fase faríngea e o tempo de inicio do movimento do hióide (Tabela 2), constatou-se que houve um aumento do mesmo para os pacientes com distonia laríngea em relação aos controles $(p=$ $0,01)$.

Na comparação dos grupos controle, pré e pós-aplicação da toxina botulínica, para as consistências líquida e pastosa, na relação do tempo de depuração faríngea com o tempo do movimento do osso hióide, observamos que não houve diferença significativa na comparação entre os grupos, para ambas as consistências (Tabela 3). 
Tabela 1 - Comparações dos grupos controle e pacientes com distonia laríngea préaplicação e pós-aplicação da toxina botulínica, considerando os tempos de trânsito para a consistência líquida

\section{Controle Distonia Laríngea}

\section{Líquida}

(ms)

$$
\text { Pré - Aplicação Pós - Aplicação }
$$

\begin{tabular}{|c|c|c|c|c|c|c|}
\hline & Média & IC 95\% & Média & IC 95\% & Média & IC 95\% \\
\hline TDPO & 1537 & $1239-1835$ & 1279 & $942-1617$ & 1239 & $876-1602$ \\
\hline тто & 739 & $624-855$ & 1092 & $914-1270$ & 945 & $797-1093$ \\
\hline TTF & $447^{*}$ & $423-472$ & 364 & $335-392$ & 356 & $332-381$ \\
\hline TDF & 663 & $634-693$ & 672 & $612-733$ & 706 & $635-776$ \\
\hline TTES & $473^{* *}$ & $448-498$ & 437 & $408-465$ & 407 & $381-434$ \\
\hline TMH & 1179 & $1098-1260$ & 1372 & $1257-1487$ & 1403 & $1232-1575$ \\
\hline TOFE & 1124 & $1021-1227$ & 1432 & $1262-1603$ & 1312 & $1160-1464$ \\
\hline IFF - IMH & $132^{+}$ & $111-152$ & 221 & $152-290$ & 243 & $175-311$ \\
\hline
\end{tabular}

TDPO - Tempo de preparação oral.

TTO - Tempo de trânsito oral.

TTF - Tempo de trânsito faringeo.

TDF - Tempo de depuração faríngea.

TTES - Tempo de trânsito pelo esfíncter esofágico superior.

TMH - Tempo de movimento do hioide.

TOFE - Tempo de trânsito orofaríngeo esofágico.

IMH - Inicio do movimento do Hióide.

IFF - Inicio da fase faríngea 
Tabela 2 - Comparações dos grupos controle e pacientes com distonia laríngea préaplicação e pós-aplicação da toxina botulínica considerando os tempos de trânsito para a consistência pastosa

\begin{tabular}{|c|c|c|c|c|c|c|}
\hline \multirow{3}{*}{$\begin{array}{c}\text { Pastosa } \\
\text { (ms) }\end{array}$} & \multirow{2}{*}{\multicolumn{2}{|c|}{ Controle }} & \multicolumn{4}{|c|}{ Distonia Laríngea } \\
\hline & & & \multicolumn{2}{|c|}{ Pré - Aplicação } & \multicolumn{2}{|c|}{ Pós - Aplicação } \\
\hline & Média & IC 95\% & Média & IC 95\% & Média & IC 95\% \\
\hline TDPO & 2218 & $1816-2619$ & 3215 & $1478-4953$ & 2379 & $1684-3074$ \\
\hline TTO & $847^{*}$ & $656-1039$ & 1158 & $929-1386$ & 970 & $796-1143$ \\
\hline TTF & $437^{*^{+}}$ & $408-466$ & $401^{* *}$ & $365-437$ & 366 & $338-394$ \\
\hline TDF & 639 & $610-668$ & 782 & $684-880$ & 762 & $658-865$ \\
\hline TTES & 448 & $423-473$ & 450 & $417-483$ & 420 & $391-448$ \\
\hline TMH & $1250^{\circ}$ & $1166-1334$ & 1524 & $1381-1666$ & 1412 & $1271-1554$ \\
\hline TOFE & 1275 & $1083-1467$ & 1480 & $1264-1696$ & 1302 & $1134-1470$ \\
\hline IFF - IMH & $149^{\star \star *}$ & $115-183$ & 260 & $146-374$ & 223 & $132-314$ \\
\hline \multicolumn{3}{|c|}{$\begin{array}{l}* p=0,03 \text { (controle } x \text { pré-aplicação) } \\
* * p=0,05 \text { (pré x pós-aplicação) } \\
* * * p=0,01 \text { (controle x pré e pós-aplicação) } \\
\text { TDPO - Tempo de preparação oral. }\end{array}$} & & $\begin{array}{l}+p<0,01 \text { (cont } \\
{ }^{\circ} p=0,02 \text { (cont } \\
\text { IC }=\text { Intervalo } c\end{array}$ & $\begin{array}{l}\text { le x pós-a } \\
\text { le x pré-a } \\
\text { Confiança }\end{array}$ & $\begin{array}{l}\text { icação) } \\
\text { icação) }\end{array}$ \\
\hline \multicolumn{7}{|c|}{ TTO - Tempo de trânsito oral. } \\
\hline \multicolumn{7}{|c|}{ TTF - Tempo de trânsito faringeo } \\
\hline \multicolumn{7}{|c|}{ TDF - Tempo de depuração faríngea. } \\
\hline \multicolumn{7}{|c|}{ TTES - Tempo de trânsito pelo esfíncter esofágico superior. } \\
\hline \multicolumn{7}{|c|}{ TMH - Tempo de movimento do hioide. } \\
\hline \multicolumn{7}{|c|}{ TOFE - Tempo de trânsito orofaríngeo esofágico. } \\
\hline IMH - Inicio c & novimen & do Hióide. & & & & \\
\hline nicio & farín & & & & & \\
\hline
\end{tabular}


Tabela 3 - Comparação entre os grupos controle, pré-aplicação e pós-aplicação da toxina botulínica, nas consistências líquida e pastosa, considerando a relação entre a duração da depuração faríngea e a duração do movimento do osso hióide

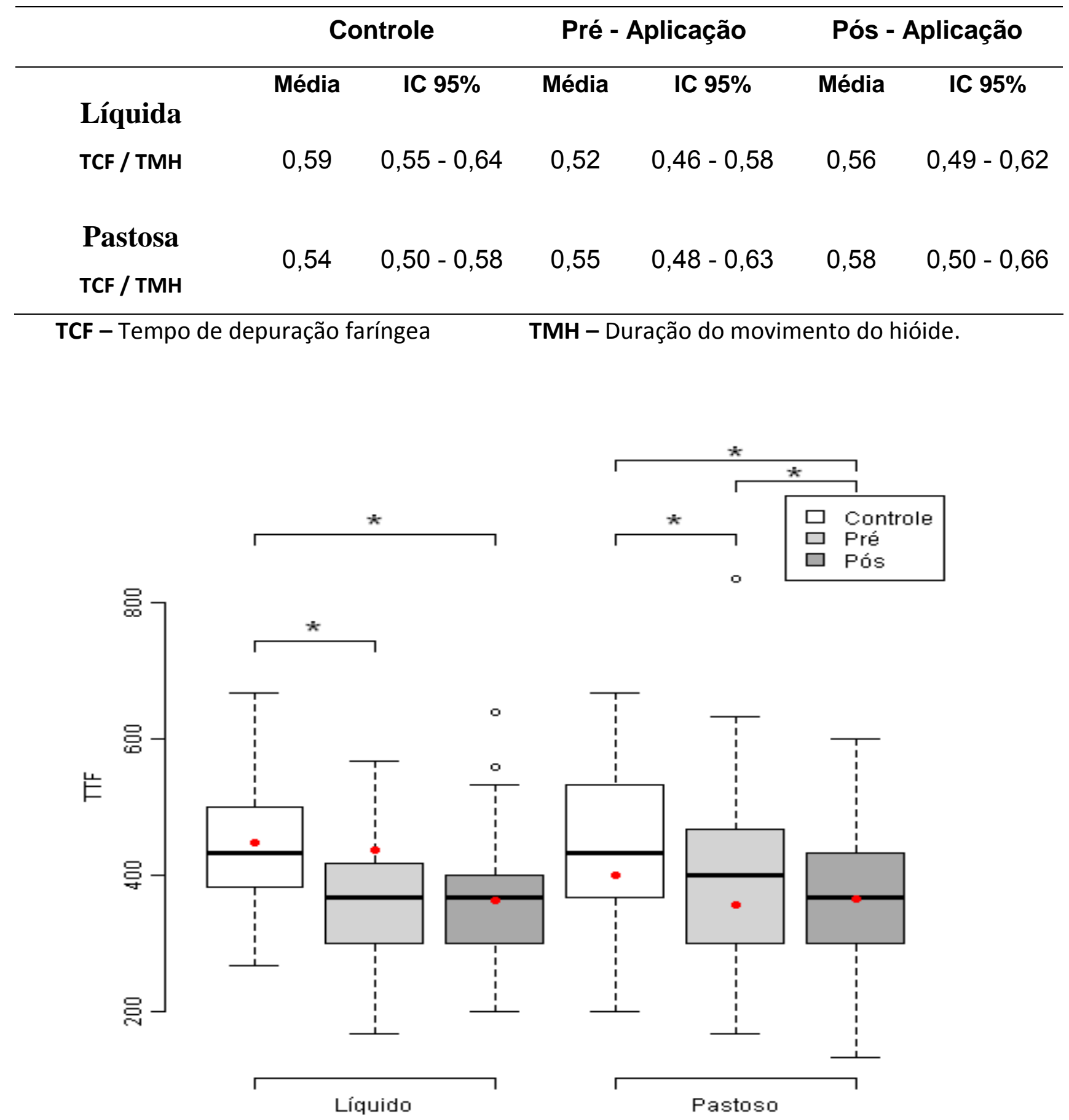

Figura 4 - Comparação do tempo de transito faríngeo (TTF) após a deglutição de bolo líquido e pastoso nos grupos controle, pré e pós-aplicação da toxina botulínica
$*: p \leq 0,05$
- : Média
: Mediana

TTF -Tempo de transito faringeo em milissegundos 


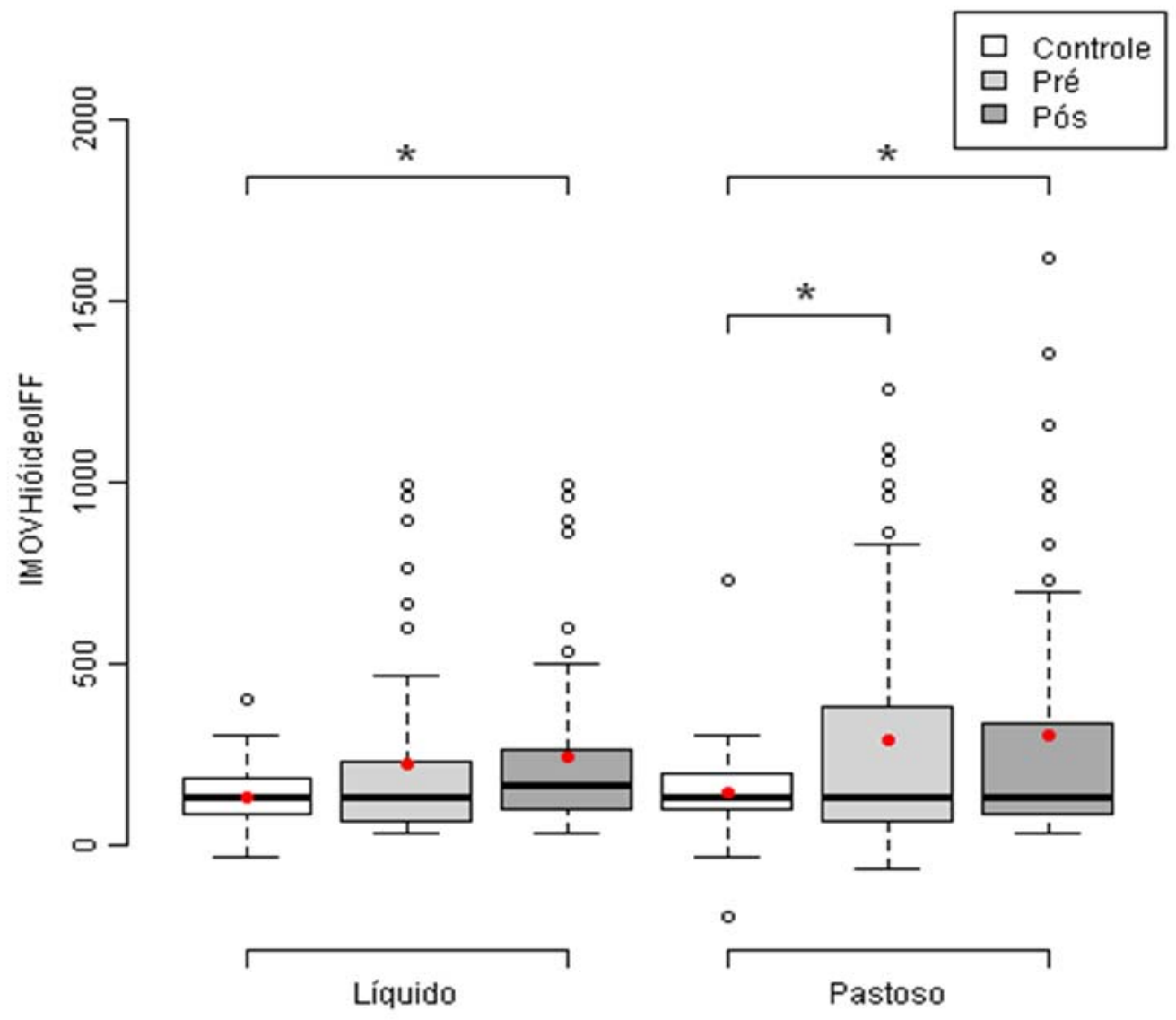

Figura 5 - Relação do inicio da fase faríngea com o inicio do movimento do osso hióide após a deglutição dos bolos líquidos e pastosos nos grupos controle, pré e pós-aplicação da toxina botulínica

$*_{p=0,05}$ (controle $x$ pós-aplicação) $\quad *_{p=0,01}$ (controle $x$ pré e pós-aplicação)

-: Média - : Mediana

IFF - IMH - Inicio da fase faríngea e Inicio do movimento do osso hióide. 


\subsection{AVALIAÇÃO QUALITATIVA DA DEGLUTIÇÃO}

Nesta avaliação, verificou-se que dos 17 pacientes avaliados, 4 apresentaram distonia cervical associada a distonia laríngea, e estes, demonstraram a presença de resíduo em valécula e aparente elevação de laringe ineficiente (determinada pela observação da elevação de laringe sem a realização da deglutição propriamente dita), mudança postural de cabeça, posicionando-a para traz e presença de escape para o bolo deglutido no período pré-aplicação. Já no período pós-aplicação, observou-se aparentemente, a presença da elevação de laringe ineficiente com sobras de resíduos em região oral, valécula, e seios piriformes.

Três pacientes apresentavam distonia generalizada, associada á distonia laríngea, e no período pré-aplicação da toxina, estes demonstraram presença de menor quantidade de resíduos do que nos pacientes pós-aplicação, na região oral, valécula e seios piriformes, presença de mudança postural de cabeça, posicionandoa para traz e para frente durante as deglutições, presença de escape de bário durante as deglutições e aparente elevação ineficiente de laringe. No período pósaplicação verificou-se presença de resíduos na região oral, valécula e seios piriformes em maior quantidade do que no período pré-aplicação, mudança postural de cabeça, com esta posicionada para traz durante as deglutições e aparente elevação ineficiente de laringe.

Quatro pacientes tinham blefaroespasmo associado à distonia laríngea, e estes, demonstraram no período pré-aplicação da toxina, presença de resíduos em valécula e aparentemente elevação ineficiente da laringe, mudança postural de cabeça, com a mesma posicionada para traz durante as deglutições dos bolos ofertados e presença de escape de bário durante as deglutições. Já no período pósaplicação aparentemente, observou-se uma redução do número de elevações laríngeas, presença de resíduos em região oral e valécula e em valécula e seios piriformes.

Um paciente apresentou tremor vocal associado com a distonia laríngea, e este, no período pré-aplicação apresentou presença de resíduos em região oral e valécula durante as deglutições. No pós-aplicação verificou-se presença de resíduos, além das duas regiões já citadas, também em seios piriformes. Um paciente apresentou tremor oromandibular associado á distonia laríngea, e este demonstrou a presença de resíduos em valécula, mesmo após a realização de mais 
de uma deglutição, no período pré-aplicação da toxina botulínica. No período pósaplicação o mesmo apresentou presença de resíduos nas regiões oral, valécula e dos seios piriformes.

Um paciente apresentou tremor em região cefálica, associado à distonia laríngea, este apresentou no período pré-aplicação, presença de escape e posicionamento de cabeça para traz durante as deglutições dos bolos ofertados. Já no período pós-aplicação o mesmo apresentou presença de resíduos em região oral e valécula.

O paciente com ataxia, associada à distonia laríngea, apresentou tanto no período pré quanto no pós-aplicação, presença de mudança de postura de cabeça, com a mesma para traz, aparente presença de elevação ineficiente da laringe e resíduos em região de valécula e seios piriformes durante as deglutições.

O paciente com disfonia psicogênica associada à distonia laríngea, apresentou tanto no período pré quanto no pós-aplicação da toxina botulínica presença de resíduos em região oral e valécula após as deglutições dos bolos oferecidos.

O paciente com distonia orofacial, associada à distonia laríngea apresentou no período pré-aplicação, a presença de mudança postural de cabeça, com esta posicionada para traz, e escape de bário durante as deglutições. No período pósaplicação o mesmo apresentou presença de resíduos na região oral e em valécula após as deglutições dos bolos ofertados (Anexo I).

Durante a avaliação qualitativa, para a variável penetração, aspiração e escape das consistências líquida e pastosa, entre os grupos controle, pré e pósaplicação (Tabelas 4 e 5), constatou-se que não houve diferença significante na comparação entre os três grupos estudados. 
Tabela 4 - Comparação entre os grupos controle, pré-aplicação e pós-aplicação, para a penetração, aspiração e o escape na consistência líquida

\begin{tabular}{c|cccccc}
\hline \multirow{2}{*}{ Líquida } & \multicolumn{2}{c}{ Controle } & \multicolumn{2}{c}{ Pré - Aplicação } & \multicolumn{2}{c}{ Pós - Aplicação } \\
& $\%$ & $\mathbf{N}$ & $\%$ & $\mathbf{N}$ & $\%$ & $\mathbf{N}$ \\
\hline Penetração & 5 & 1 & 11,7 & 1 & 5 & 1 \\
Aspiração & 0 & 0 & 5,8 & 1 & 0 & 0 \\
Escape & 40 & 8 & 35,3 & 6 & 47 & 8 \\
\hline
\end{tabular}

Tabela 5 - Comparação entre os grupos controle, pré-aplicação e pós-aplicação, para a penetração, aspiração e o escape na consistência pastosa

\begin{tabular}{c|cccccc}
\hline \multirow{2}{*}{ Pastosa } & \multicolumn{2}{|c}{ Controle } & \multicolumn{2}{c}{ Pré - Aplicação } & \multicolumn{2}{c}{ Pós - Aplicação } \\
& $\%$ & $\mathbf{N}$ & $\%$ & $\mathbf{N}$ & $\%$ & $\mathbf{N}$ \\
\hline Penetração & 0 & 0 & 5,8 & 1 & 5,8 & 1 \\
Aspiração & 0 & 0 & 0 & 0 & 0 & 0 \\
Escape & 25 & 5 & 47 & 9 & 35,2 & 6 \\
\hline
\end{tabular}

Os pacientes, após a aplicação da toxina botulínica, tiveram maior ocorrência de resíduos em cavidade oral, valécula e seios piriformes, tanto para a consistência líquida quanto para a pastosa, do que os do grupo controle $(p<0,01)$ (Tabelas 6 e 7).

Tabela 6 - Comparação entre os grupos controle, pré-aplicação e pós-aplicação para os resíduos na consistência líquida

\begin{tabular}{ccccccc}
\hline \multirow{2}{*}{ Líquida } & \multicolumn{2}{c}{ Controle } & \multicolumn{2}{c}{ Pré - Aplicação } & \multicolumn{2}{c}{ Pós - Aplicação } \\
& $\%$ & $\mathbf{N}$ & $\%$ & $\mathbf{N}$ & $\%$ & $\mathbf{N}$ \\
\hline Resíduo Oral & $15^{*}$ & 3 & 0 & 0 & 0 & 0 \\
$\begin{array}{c}\text { Resíduo Oral e Valécula } \\
\begin{array}{c}\text { Resíduo Oral, Valécula e } \\
\text { Seios Piriformes }\end{array}\end{array}$ & 75 & 15 & 58,8 & 10 & 47 & 8 \\
\hline$* p=0,04$ (controle x pré-aplicação) & 2 & 41,2 & 7 & 53 & 9 \\
\hline
\end{tabular}


Tabela 7 - Comparação entre os grupos controle, pré-aplicação e pós-aplicação para os resíduos na consistência pastosa

\begin{tabular}{ccccccc}
\hline \multirow{2}{*}{ Pastosa } & \multicolumn{2}{c}{ Controle } & \multicolumn{2}{c}{ Pré - Aplicação } & \multicolumn{2}{c}{ Pós - Aplicação } \\
& $\%$ & $\mathbf{N}$ & $\%$ & $\mathbf{N}$ & $\%$ & $\mathbf{N}$ \\
\hline $\begin{array}{c}\text { Resíduo Oral } \\
\text { Resíduo Oral e Valéculas }\end{array}$ & 55 & 11 & 58,8 & 10 & 58,8 & 10 \\
$\begin{array}{c}\text { Resíduo Oral, Valéculas e } \\
\text { Seios Piriformes }\end{array}$ & $5^{*}$ & 1 & 23,5 & 4 & 35,2 & 6 \\
$*_{\mathrm{p}=0,01 \text { (controle x pós-aplicação) }}$ & & & & & &
\end{tabular}

$\mathrm{Na}$ avaliação do número de deglutições necessárias para deglutir todo volume ofertado, constatou-se que para a consistência líquida, não houve diferença entre os grupos, mas com a consistência pastosa, 88\% dos pacientes pré-aplicação, realizaram duas deglutições, enquanto entre os controles $40 \%$ realizaram uma deglutição e $40 \%$ realizaram duas $(p<0,01)$ (Tabelas 8 e 9).

Tabela 8 - Comparações entre os grupos controle, pré-aplicação e pós-aplicação para o número de deglutições na consistência líquida

\begin{tabular}{ccccccc}
\hline Número de Deglutições & \multicolumn{2}{c}{ Controle } & \multicolumn{2}{c}{ Pré - Aplicação } & \multicolumn{2}{c}{ Pós - Aplicação } \\
\hline Líquida & $\%$ & $\mathbf{N}$ & $\%$ & $\mathbf{N}$ & $\%$ & $\mathbf{N}$ \\
$\mathbf{1}$ & 25 & 5 & 0 & 0 & 5,8 & 1 \\
$\mathbf{2}$ & 50 & 10 & 70,5 & 12 & 64,7 & 11 \\
$\mathbf{3}$ & 15 & 3 & 11,7 & 2 & 23,5 & 4 \\
$\mathbf{4}$ & 10 & 2 & 17,6 & 3 & 5,8 & 1 \\
\hline
\end{tabular}

Tabela 9 - Comparações entre os grupos controle, pré-aplicação e pós-aplicação para o número de deglutições na consistência pastosa

\begin{tabular}{ccccccc}
\hline Número de Deglutições & \multicolumn{2}{c}{ Controle } & \multicolumn{2}{c}{ Pré - Aplicação } & \multicolumn{2}{c}{ Pós - Aplicação } \\
\hline Pastosa & $\%$ & $\mathbf{N}$ & $\%$ & $\mathbf{N}$ & $\%$ & $\mathbf{N}$ \\
$\mathbf{1}$ & $40^{*}$ & 8 & 0 & 0 & 11,7 & 2 \\
$\mathbf{2}$ & $40^{*}$ & 8 & 88,2 & 15 & 52,9 & 9 \\
$\mathbf{3}$ & $15^{*}$ & 3 & 11,7 & 2 & 29,4 & 5 \\
$\mathbf{4}$ & 5 & 1 & 0 & 0 & 5,8 & 1 \\
\hline
\end{tabular}

$* p<0,01$ (controle x pré-aplicação) 


\subsection{ANAMNESE FONOAUDIOLÓGICA}

Nas comparações entre os grupos controle e pré-aplicação e entre os grupos pré e pós-aplicação para as variáveis, hábito de fumar, ingestão de bebidas alcoólicas, queixa de disfagia, de tosse e de engasgo, nenhuma diferença estatística foi observada (Tabelas 10 e 11).

Tabela 10 - Comparação entre os grupos controle e pré-aplicação para as variáveis da anamnese fonoaudiológica

\begin{tabular}{ccccccc}
\hline & & \multicolumn{2}{c}{ Controle } & \multicolumn{2}{c}{ Pré - Aplicação } & \multicolumn{2}{c}{ Valor de } \\
& & $\%$ & $\mathbf{N}$ & $\%$ & $\mathbf{N}$ & P \\
\hline \multirow{2}{*}{ Hábito de Fumar } & Sim & 10 & 2 & 17,7 & 3 & 0,64 \\
& Não & 90 & 18 & 82,4 & 14 & \\
Ingestão de Bebidas & Sim & 45 & 9 & 47,1 & 8 & \multirow{2}{*}{0,99} \\
Alcóolicas & Não & 55 & 11 & 52,9 & 9 & \\
\hline
\end{tabular}

Tabela 11 - Comparação entre os grupos pré-aplicação e pós-aplicação para as variáveis da anamnese fonoaudiológica

\begin{tabular}{ccccccc}
\hline & & \multicolumn{2}{c}{ Pré - Aplicação } & \multicolumn{2}{c}{ Pós - Aplicação } & Valor de \\
& & \% & N & $\%$ & N & P \\
\hline \multirow{2}{*}{ Hábito de Fumar } & Sim & 17,7 & 3 & 17,7 & 3 & 0,64 \\
& Não & 82,4 & 14 & 82,4 & 14 & \\
Ingestão de Bebidas & Sim & 47 & 8 & 41,2 & 7 & \multirow{2}{*}{0,99} \\
Alcóolicas & Não & 53 & 9 & 58,8 & 10 & \\
Queixa de Disfagia & Sim & 35,3 & 6 & 23,5 & 4 & \multirow{2}{*}{0,41} \\
& Não & 64,7 & 11 & 76,5 & 13 & \\
Tosse & Sim & 94,1 & 16 & 17,6 & 3 & 0,32 \\
& Não & 5,8 & 1 & 82,3 & 14 & \\
Engasgo & Sim & 11,7 & 2 & 17,6 & 3 & 0,65 \\
& Não & 88,2 & 15 & 82,3 & 14 & \\
\hline
\end{tabular}




\section{DISCUSSÃO}

No presente trabalho, foi realizada a avaliação videofluoroscópica da deglutição, nos pacientes com distonia laríngea, antes e 30 dias após a aplicação da toxina botulínica.

Ao longo dos anos, várias investigações instrumentais têm sido utilizadas em estudos da deglutição, ao lado da videofluoroscopia, como a videoendoscopia, a cintilografia, a ecografia, e a manometria, mas a videofluoroscopia ainda mantém um papel determinante na obtenção de mais dados de diagnóstico detalhados na avaliação das fases oral e faríngea da deglutição (RUGIU, 2007).

A videofluoroscopia é considerada o método padrão-ouro no estudo de deglutição e suas disfunções. Videofluoroscopia da deglutição é o processo de gravação de eventos da deglutição dinâmicos usando raios- $X$ e armazenamento de informações em meio magnético. Esse método permite a gravação de alta resolução em tempo real a 30 frames/s ou mais, o que permite não só as análises morfológicas, mas também a avaliação fisiológica. No Brasil, esta técnica permanece subutilizada (COSTA, 2010).

A eletromiografia (EMG) é um exame que avalia o comportamento elétrico e a integridade da unidade motora: o motoneurônio inferior, seu axônio, a placa mioneural e fibra muscular. É considerado exame complementar fundamental em desordens do movimento e extensamente utilizada em Ortopedia e Neurologia. No final da década de 80 e início da de 90, a eletromiografia laríngea (EMGL) foi adicionada ao arsenal de abordagem diagnóstica e terapêutica da laringe e das desordens da voz (ZARZUR; SHINZATO, 2007).

SATALOFF et al. (2004), caracterizaram as eletromiografias laríngeas (EMGS), como uma técnica para uso no diagnóstico, prognóstico e tratamento das desordens de movimentação laríngea, incluindo as distonias laríngeas, a paralisia de pregas vocais e outras desordens neurológicas. Referiram que é evidente sua utilidade para injeção de toxina botulínica dentro do músculo tireoaritenóideo, no tratamento de disfonia espasmódica adutora. 


\subsection{EFEITO DA DISTONIA LARÍNGEA NA DEGLUTIÇÃO}

\subsubsection{AVALIAÇÃO VIDEOFLUOROSCÓPICA}

Os grupos pré e pós-aplicação apresentaram o tempo de trânsito faringeo menor do que o grupo controle para ambas as consistências avaliadas. Em relação aos tempos de trânsito oral e do movimento do osso hióide, para a consistência pastosa, verificou-se que o grupo pré-aplicação apresentou um tempo maior para ambas as variáveis do que o grupo controle.

O trânsito faringeo, para ambas as consistências, e a duração do trânsito pelo esfíncter superior do esôfago, para a consistência líquida, apresentaram-se menor para o grupo pós-aplicação em relação ao controle.

$\mathrm{Na}$ relação do movimento do osso hióide com o tempo de início da fase faríngea, na comparação entre os grupos controle e dos pacientes pós-aplicação para a consistência líquida, verificou-se que houve diferença significante. Já nas comparações dos grupos controle com o pré-aplicação e deste com o pós-aplicação, para a consistência pastosa, observamos diferença para ambas às comparações, respectivamente. Podemos constatar que para a consistência pastosa a diferença nas comparações realizadas entre os grupos, apresentou-se maior do que para a consistência líquida.

Um número maior de pacientes do grupo pós-aplicação e uma quantidade maior de resíduo nas regiões oral, oral e valécula e oral, valécula e seios piriformes foram encontradas para as consistências líquida e pastosa consecutivamente, em relação aos controles.

O grupo com distonia laríngea apresentou mais escape durante as deglutições, o que pode ser em função da própria distonia e idade dos pacientes, e maior número de deglutições para a consistência pastosa, do que os indivíduos do grupo controle.

Os achados deste estudo podem ser caracterizados, pelo fato do volume das consistências exigirem um controle maior das estruturas envolvidas na deglutição e também pela adaptação do paciente em relação ao seu problema, já que o transito oral apresentou-se mais lento, como se fosse uma preparação da consistência a ser deglutida para as fases seguintes. Os estudos a seguir comentam sobre estes achados: 
Indivíduos saudáveis de 40 a 60 anos, apresentam local de inicio da fase faríngea abaixo da projeção do ângulo da mandíbula e com o aumento da idade eles tendem a apresentar com mais frequência o inicio da fase faríngea inferior à projeção do ângulo da mandíbula e aumento do tempo de transito faringeo para o volume de $5 \mathrm{ml}$ na consistência líquida (VALE-PRODOMO, 2010).

Neste estudo, tanto os participantes do grupo controle, como os pacientes com distonia laríngea, não demonstraram diferença significativa na correlação entre a depuração faríngea e o movimento do osso hióide e este evento também é referido no estudo abaixo:

Em investigação videofluoroscópica, com volume de $5 \mathrm{ml}$ líquido, realizada em 82 indivíduos saudáveis (média 58 anos), para determinar o sincronismo entre a localização da cabeça do bolo deglutido, sua relação com o início do movimento do osso hióide no início da deglutição faríngea, verificou-se que $80 \%$ dos participantes apresentaram o início do movimento hióide e o inicio da fase faríngea da deglutição após a cabeça bolo passar pelo ângulo posterior da mandíbula. Os participantes mais velhos iniciavam o movimento do hióide mais tardiamente. Portanto, estes dados demonstram que um "atraso", por si só, não pode indicar uma deglutição desordenada, sem coexistir deficiências na fisiologia da deglutição (HARRIS, 2007).

\subsubsection{ANAMNESE FONOAUDIOLÓGICA}

Os achados obtidos durante a anamnese fonoaudiológica, como queixa de disfagia, em 6 dos 17 pacientes pré-aplicação da toxina botulínica, podem ser pelo fato da distonia laríngea se caracterizar por um grande número de espasmos e a uma incoordenação e enfraquecimento da musculatura envolvida com a deglutição, a mudança postural de cabeça, muito frequente durante a avaliação videofluoroscópica da deglutição e principalmente se estiver associada a outros tipos de distonia, como já mencionado anteriormente, podendo levar a um maior número de resíduos nas regiões oral, oral e valécula, e oral, valécula e seios piriformes, e maior número de deglutições. Os estudos a seguir confirmam estes achados:

Os pacientes com distonia cervical podem apresentar cabeça inclinada, giro, flexão, extensão ou uma combinação destas posturas de cabeça, sendo que a postura de flexão ocorre em $25 \%$ dos casos da distonia cervical (GRAHAM et al., 2009). 
Os sintomas iniciais das distonias podem incluir uma sensação de aperto/tensão sem dor, fadiga e falta de habilidade com o subsequente desenvolvimento da ativação incontrolável dos músculos que se encontram ao redor com movimentos anormais e altamente qualificados durante uma atividade motora específica (RUSSOTTOA; PERLMUTTERA, 2008).

As dificuldades graves de deglutição durante os períodos de espasmos, na distonia laríngea, são caracterizadas por uma tensa constrição ao nível da garganta do sujeito. Uma anormalidade ao nível do músculo cricofaríngeo terá um duplo efeito, tanto sobre as propriedades acústicas da voz quanto na deglutição (ERTEKIN et al., 2002).

Pacientes que sofrem de distonia oromandibular, muitas vezes enfrentam dificuldades na mastigação, deglutição e fala resultante da deficiência dos movimentos mandibulares. A distonia pode também envolver a língua, particularmente durante a alimentação e, como consequência, o alimento pode ser empurrado para fora da boca. Muitos pacientes reprimem temporariamente esses movimentos distônicos/espasticos com toques leves no queixo ou nos lábios, aplicando uma pressão nos mesmos (MICHELOTTI et al., 2009).

A distonia segmentar cranial pode comprometer a musculatura palpebral, a musculatura oromandibular (podendo atingir a musculatura perioral, mastigatória e da língua) bem como a laringe. Assim, pode haver alteração da fala por causa da distonia extra laríngea com comprometimento da articulação, bem como secundária às distonias que comprometem o trato vocal e modificam a ressonância (KORN et al., 2011).

Até o término deste estudo, foram mencionados poucos trabalhos com metodologia semelhante utilizando a avaliação videofluoroscópica. Talvez isto se dê pelo fato da distonia laríngea, geralmente vir acompanhada de outros tipos de distonias, o que dificulta a afirmação mais segura dos achados e também pelo fato da TBX ser um tratamento relativamente recente nos indivíduos com esta dificuldade.

\subsection{EFEITO DA TOXINA BOTULÍNICA NA DEGLUTIÇÃO}

\subsubsection{AVALIAÇÃO VIDEOFLUOROSCÓPICA E ANAMNESE FONOAUDIOLOGICA}

Na comparação entre os grupos, o tempo de trânsito faríngeo foi maior para o grupo pré-aplicação do que para o grupo pós-aplicação, para a consistência pastosa. 
A proporção do tempo de depuração faríngea com o tempo do movimento do osso hióide, não demonstrou diferença na comparação entre os grupos, para ambas as consistências.

Observamos que mais pacientes pós-aplicação, apresentaram escape de bário para o líquido do que os pré-aplicação. Mais pacientes pré-aplicação, apresentaram penetração e aspiração de bário na consistência líquida, do que os pacientes pós-aplicação. O mesmo número de pacientes, para ambos os grupos, apresentaram penetração e aspiração para a consistência pastosa. Mais pacientes pré-aplicação apresentaram escape de bário para a consistência pastosa do que os pós-aplicação.

A queixa de disfagia foi frequente entre os pacientes pré-aplicação da BTX. Pois, 10 dos 17 pacientes relataram esta queixa, sendo que destes 2 apresentaram a queixa tanto no período pré quanto no pós-aplicação (sendo $1 \mathrm{com}$ distonia laríngea isolada e $1 \mathrm{com}$ distonia generalizada), 4 apresentaram queixa apenas após aplicação (2 distonia laríngea isolada, 1 com blefaroespasmo e distonia cervical associada a distonia laríngea, 1 com distonia generalizada) , e 6 pacientes referiram a queixa apenas no período pré-aplicação da toxina (1 com distonia generalizada, 1 com disfonia psicogênica associada a distonia laríngea, e 2 com distonia laríngea isolada, $1 \mathrm{com}$ distonia generalizada associada a distonia laríngea e $1 \mathrm{com}$ tremor oromandibular associado a distonia laríngea).

Os achados encontrados neste estudo são confirmados pelos estudos a seguir:

No estudo de pacientes com distonia laríngea que utilizavam toxina botulínica, verificou-se que a presença de disfagia foi encontrada em $37,2 \%$ dos pacientes que realizavam reaplicações da BTX-A, e em 44,2\% dos pacientes que realizavam primeira aplicação da BTX-A. A disfagia apresentou curta duração em ambos os grupos mencionados, demonstrando uma média de 1,4 dias versus 2,4 dias. Os efeitos colaterais da disfagia pós-injeção da toxina, foram semelhantes para os dois tipos de tratamento (THOMAS; SIUPSINSKIENE, 2006).

Após injeção local, a TBX-A difunde-se pelos músculos e outros tecidos. Seu efeito concentra-se próximo ao ponto de aplicação e diminui com o aumento da distância com relação a esse ponto. A difusão para músculos vizinhos é possível, especialmente quando volumes elevados são utilizados, podendo ocasionar eventos adversos (MOORE; NAUMANN, 2003). 
Parece haver relação entre o surgimento de disfagia e a difusão de TBX-A, seja pela aplicação de altas doses, seja pelos músculos injetados. Boca seca, paralisia da prega vocal e fraqueza da musculatura cervical também podem ocorrer (BRASIL, 2009).

A sialorréia, na Doença de Parkinson, tem sido tratada com a injeção de BTX nas glândulas parótidas. Nos pacientes avaliados antes da videofluoroscopia da deglutição e 30 dias após a injeção da BTX, observou-se a diminuição da sialorréia em todos os pacientes. A injeção da BTX nas glândulas parótidas não interferiu na dinâmica orofaríngea da deglutição desses pacientes (NOBREGA et al., 2009).

Os pacientes com esclerose múltipla, associada à disfagia com hiperatividade do esfíncter superior do esôfago (ESE), apresentaram uma melhora nas medidas da deglutição, e há um grande benefício da BTX no tratamento destes pacientes (RESTIVO et al., 2011). Os pacientes com disfagia associada à hiperatividade do músculo cricofaríngeo melhoram após a injeção da BTX neste músculo, em combinação com as modificações dietéticas, as técnicas posturais e as manobras de proteção do fluxo de ar. Após 2 meses da injeção de BTX os pacientes, que eram alimentados via gastrostomia, voltaram para a alimentação oral sem sinais de aspiração, demonstrando melhora da disfagia (RESTIVO et al., 2006).

Lee et al. (2009), avaliaram o efeito das injeções da BTX na disfagia acompanhada pela disfunção do ESE e verificaram que após a aplicação os resíduos no seio piriforme diminuíram, e que a injeção da BTX no esfíncter superior do esôfago melhorou a função de deglutição, demonstrando ser uma opção terapêutica possível nestes pacientes.

Os pacientes com distonia laríngea, tratados com injeções de BTX nas cordas vocais, usando uma técnica percutânea sob orientação da EMG, apresentaram melhorias da função vocal normal. Os efeitos adversos foram leves e transitórios. A hipofonia afetou $61,3 \%$ dos pacientes com duração média de 11,3 dias. A disfagia foi relatada em $44,1 \%$ dos casos com duração média de 5,8 dias (LARROSA et al., 2002).

Um estudo de pacientes com distonia laríngea, antes e após tratamento com injeção de BTX, encontrou atividade aumentada do córtex sensório-motor nos pacientes não tratados, e a normalização desta atividade após o tratamento com injeção muscular de BTX (ALI et al., 2006). 
Com o uso da BTX, para o tratamento da distonia laríngea, os espasmos musculares são reduzidos não apenas no músculo injetado, mas também em outros músculos laringeais, e no lado oposto da laringe, o feedback sensorial da laringe é alterado pela redução da compressão da mucosa e redução da pressão subglótica na traquéia devido à redução da hiper adução durante a fala (LUDLOW, 2011).

A falta de sintomas durante sussurro quando as pregas vocais não estão vibrando sugere que as mudanças no feedback sensorial da laringe ou da mucosa das pregas vocais, ou pressões subglóticas na traquéia, podem desempenhar um papel na fisiopatologia da doença. Uma hipótese, então, pode ser que a fisiopatologia pode envolver feedback sensorial da periferia da laringe, afetando a fisiologia cortical da disfonia espasmódica (LUDLOW, 2011).

A injeção de toxina botulínica pode causar uma profunda redução da espasticidade em áreas maiores que as esperadas e não relacionadas com a área de dispersão do medicamento (AOKI, 2001).

Em estudo de 126 pacientes com distonia focal, sendo 89 com distonia cervical, 12 com cãibras nas mãos e 25 com distonia laríngea, que foram tratados com injeções localizadas de toxina botulínica, com dose de 3,7 m.u. no músculo tireoaritenóideo em pacientes com distonia laríngea, observou-se que os efeitos colaterais mais comuns foram a disfagia após o tratamento do torcicolo espasmódico, fraqueza dos músculos vizinhos, após injeções para cãibras nas mãos e soprosidade e hipofonia após injeções na laringe. Conclui-se que as injeções de toxina botulínica demonstraram ser um tratamento seguro e eficaz em todos os tipos de distonia focal (LEES et al., 1992).

Anormalidades faringeais em ambas as distonias, cervical e oromandibular, incluem resíduo faringeal pós-deglutição, particularmente na valécula. $O$ transporte assimétrico do bolo é mais propenso de ocorrer na distonia cervical (HORNER, 1993; RISKI, 1990).

No estudo de Coelho et al. (2010), 100\% dos pacientes tratados com injeção de BTX apresentaram melhora significativa, e a avaliação da melhora do paciente foi feita de maneira subjetiva através da opinião do paciente. Casserly et al. (2008), acreditam que esta seja uma maneira adequada de se avaliar o resultado desse tratamento, visto que não se trata de tratamento curativo e sim para alívio sintomático. 
Avaliação videofluoroscópica dos pacientes com distonia cervical geralmente tem mostrado atraso no início da deglutição e resíduo faríngeo. O tratamento com toxina botulínica e rizotomia pode aumentar os sinais de disfagia ou desmascarar o potencial intrínseco de natureza neurogênica da disfagia nestes pacientes. Porém, espasmos ativos transitórios no pescoço ainda podem produzir um efeito negativo transitório e esporádico ao deglutir (ERTEKIN et al., 2002).

Os efeitos colaterais das injeções nos músculos adutores foram $25 \%$, com voz sussurrada transitória leve, 10\% com tosse transitória leve durante a deglutição de líquidos, e $<1 \%$ com dor local, hematomas ou prurido. Os efeitos colaterais das injeções nos músculos abdutores foram $2 \%$ dos pacientes com leve esforço respiratório, e 6\% com disfagia transitória leve para sólidos (BLITZER, 2010).

Os estudos apresentados relatam a presença de disfagia para diferentes consistências alimentares, fraqueza muscular e tosse, principalmente em pacientes após a aplicação da TBX-A. Neste estudo foi possível verificar que as variáveis, hábito de fumar, ingestão de bebidas alcoólicas, queixa de disfagia, tosse e engasgos não apresentaram diferença significativa nas comparações realizadas entre os grupos controle e pré-aplicação, e nem entre os grupos pré e pós-aplicação da BTX, mas a queixa de disfagia foi referida pelos pacientes, tanto no período pré quanto no pós-aplicação da toxina. Este fato pode ter ocorrido em decorrência dos sintomas da própria distonia e não pela influência da TBX.

Acredito que esses achados, podem vir a contribuir para o trabalho fonoaudiológico nos pacientes com distonia laríngea, tanto em relação aos sintomas vocais, quanto em relação á orientação aos possíveis sintomas de disfagia, como tipo de consistências mais apropriadas para o seu quadro clínico, forma de alimentação mais efetiva, adequação do ambiente das refeições e quanto à própria terapêutica, com a realização de estratégias posturais e de proteção de vias aéreas que auxiliem na melhoria da deglutição deste paciente, principalmente na fase faríngea. Para a área médica acredito que este estudo venha reforçar a idéia de que o tratamento com a toxina botulínica é seguro e desprovido de efeitos colaterais significativos em relação à deglutição. 


\section{CONCLUSÃO}

Os pacientes com distonia laríngea, comparado aos controles, têm trânsito mais rápido pela faringe, aumento de resíduos na região oral e em valécula e maior número de deglutições. Trinta dias após a aplicação da toxina botulínica foi observado diminuição da duração do trânsito pela faringe, com o bolo pastoso, e resposta tardia do movimento do osso hióide em relação à chegada do bolo na faringe. 


\section{REFERÊNCIAS}

ADLER, C. H.; BANSBERG, S. F.; HENTZ, J. G.; RAMIG, L. O.; BUDER, E. H.; WITT, K.; EDWARDS, B. W.; KREIN-JONES, K.; JOHN, N.; CAVINESS, J. N. Botulinum toxin type a for treating voice tremor. Archives of Neurology, Chicago, v. 61, n. 9, p. 1416-1420, 2004.

ALBANESE, A. Dystonia: clinical approach. Parkinsonism \& Related Disorders, Kidlington, v. 13, n. 3, p. 356-361, 2007.

ALI, S. O.; THOMASSEN, M.; SCHULZ, G. M.; HOSEY, L. A.; VARGA, M.; LUDLOW, C. L.; BRAUN, A. R. Alterations in CNS activity induced by botulinum toxin treatment in spasmodic dysphonia: an $\mathrm{H} 2150$ pet study. Journal of Speech, Language, and Hearing Research, Rockville, v. 49, n. 5, p. 1127-1146, 2006.

AOKI, K. R. Pharmacology and immunology of botulinum toxin serotypes. European Journal of Neurology, Berlin, v. 248, n. 1, p. 3-10, 2001.

BELHAU, M. S. Voz: o livro do especialista 1. Rio de Janeiro: Revinter, 2004.

BIASE, N. G.; LORENZON, P.; LEB, M. D. A.; PADOVANI, M.; GIELOW, I.; MADAZIO, G.; MORAES, M. Adduction laryngeal dystonia: proposal and evaluation of nasofibroscopy. Brazilian Journal of Otorhinolaryngology, São Paulo, v. 72, n. 4, p. 443-446, 2006.

BLITZER, A. Spasmodic dysphonia and botulinum toxin: experience from the largest treatment series. European Journal of Neurology, Oxford, v. 17, n. 1, p. 28-30, 2010.

BRASIL. Ministério da Saúde. Secretaria de Atenção à Saúde. Portaria SAS/MS n⿳0 376, de 10 de novembro de 2009. Protocólo clínico e diretrizes terapêuticas. Distonias Focais e Espasmo Hemifacial. 2009. Disponível em: < http://portal. saude.gov.br/portal/arquivos/pdf/protocolo_distonia.pdf>. Acesso em: 05/003/2011.

BRAUN, N.; ABD, A.; BAER, J.; BLITZER, A.; STEWART, C.; BRIN, M. Dyspnea in dystonia: a functional evaluation. Chest, Chicago, v. 107, n. 5, p. 1309-1316, 1995.

CAMARGO, C. H. F.; TEIVE, H. A. G.; BECKER, N.; BARAN, M. H. H.; SCOLA, R. H.; WERNECK, L. C. Cervical dystonia: clinical and therapeutic features in 85 patients. Arquivos de Neuropsiquiatria, São Paulo, v. 66, n. 1, p. 15-21, 2008. 
CANNITO, M. P.; KAHANE, J. C.; CHORNA, L. Vocal aging and adductor spasmodic dysphonia: response to botulinum toxin injection. Clinical Interventions in Aging, New Zealand, v. 3, n. 1, p. 131-151, 2008.

CASSERLY, P.; TIMON, C. Botulinum toxin-A injection under electromyographic guidance for treatment of spasmodic dysphonia. Journal of Laryngology and Otology, London, v. 122, n. 1, p. 52-56, 2008.

COELHO, M. S.; MACEDO, E.; OLIVEIRA, M. S. B.; LOBO, P.; SOCCOL, A. T.; KOERNER, H. N. Spasmodic dysphonia: description of the disease and associated neurologic disorders. Archives of Otorhinolaryngology, Heidelberg, v. 14, n. 2, p. 163-166, 2010.

COSTA, M. M. B. Videofluoroscopy: the gold standard exam for studying swallowing and its dysfunction. Arquivos de Gastroenterologia, São Paulo, v. 47, n. 4, p. 327328, 2010.

DELONG, M. R.; JUNCOS, J. L. Principles of internal medicine. 16th ed. United States: Foreign Language Editions, 2005.

DUBOW, J.; KIM, A.; LEIKIN, J.; CUMPSTON, K.; BRYANT, S.; REZAK, M. Visual system side effects caused by parasympathetic dysfunction after botulinum toxin type B injections. Movement Disorders, New York, v. 20, n. 7, p. 877-880, 2005.

DUMITRU, D.; GUITTER, J. Nerve and muscle anatomy and phsysiology: electrodiagnostic medicine. 2nd ed. Philadelphia: Hanley \& Belfus, 2002.

ELMIYEH, B.; PRASAD, V. M. N.; UPILE, T.; SAUNDERS, N.; YOUL, B. D.; EPSTEIN, R.; RUBIN, J. S. A single-centre retrospective review of unilateral and bilateral dysport ${ }^{\circledR}$ injections in adductor spasmodic dysphonia. Logopedics, Phoniatrics, Vocology, London, v. 35, n. 1, p. 39-44, 2010.

ERTEKIN, C.; AYDOGDU, I.; SEÇIL, Y.; KIYLIOGLU, N.; TARLACI, S.; OZDEMIRKIRAN, T. Oropharyngeal swallowing in craniocervical dystonia. Journal of Neurology, Neurosurgery, and Psychiatry, London, v. 73, n. 4, p. 406-411, 2002.

GLASS, G. A.; KU, S.; OSTREM, J. L.; HEATH, S.; LARSON, P. S. Fluoroscopic, emg-guided injection of botulinum toxin into the longus colli for the treatment of anterocollis. Parkinsonism \& Related Disorders, Kidlington, v. 15, n. 8, p. 610-613, 2009. 
GARY, Y.; SHAW, M. D.; SEARL, J. P. S. Botulinum toxin treatment for cricopharyngeal dysfunction. Dysphagia, New York, v. 16, n. 3, p. 161-167, 2000.

GEYER, H. L.; BRESSMAN, S. B. The diagnosis of dystonia. Lancet Neurology, London, v. 5, n. 9, p. 780-790, 2006.

GIOlTZOGlOU, T.; CORDIVARI, C.; LEE, P. J.; HANNA, M. G.; LEES, A. J. Problems with botulinum toxin treatment in mitochondrial cytopathy: case report and review of the literature. Journal of Neurology, Neurosurgery, and Psychiatry, London, v. 76, n. 11, p. 1594-1596, 2005.

HARRIS, B. M.; BRODSKY, M. B.; MICHEL, Y.; LEE, F. S.; WALTERS, B. Delayed initiation of the pharyngeal swallow: normal variability in adult swallows. Journal of Speech, Language, and Hearing Research, Rockville, v. 50, n. 3, p. 585-594, 2007.

HO, K. H.; WRIGHT, C. C.; UNDERBRINK, M. P. A rare case of laryngeal dystonia associated with neurosyphilis: response to botulinum toxin injection. Laryngoscope, St. Louis, v. 121, n. 1, p. 147-149, 2011.

HORNER, J.; RISKI, J. E.; WEBER, B. A.; NASHOLD, B. S. JR. Swallowing, speech, and brainstem auditory-evoked potentials in spasmodic torticollis. Dysphagia, New York, v. 8, n. 1, p. 29-34, 1993.

JANKOVIC, J. Botulinum toxin in clinical practice. Journal of Neurology, Neurosurgery, and Psychiatry, London, v. 75, n. 7, p. 951-957, 2004a.

JANKOVIC, J. Treatment of cervical dystonia with botulinum toxin. Movement Disorders, New York, v. 19, n. 8, p. 109-115, 2004b.

JIMENEZ-SHAHED, J. A new treatment for focal dystonias: incobotulinumtoxin A $\left(\right.$ xeomin $\left.^{\circledR}\right)$, a botulinum neurotoxin type-A free from complexing proteins. Neuropsychiatric Disease and Treatment, Albany, v. 8, n. 23, p. 13-25, 2012.

KAHN, L.; JORDAAN, H. The swallowing and voicing characteristics of pharyngeal dystonia: a single case report. South African Journal of Communication Disorders, Johannesburg, v. 48, p. 21-31, 2001.

KORN, G. P.; MORAES, M.; VILANOVA, L. C. P.; MORAES, B. T.; MADAZIO, G.; PADOVANI, M.; DE BIASE, N. G. Comparison of clinical characteristics of patients with adductor laryngeal dystonia in the focal and segmental types. Brazilian Journal of Otorhinolaryngology, São Paulo, v. 77, n. 4, p. 413-417, 2011. 
KWON, J. S.; KIM, S. T.; JEON, Y. M.; CHOI, J. H. Effect of botulinum toxin type-A injection into human masseter muscle on stimulated parotid saliva flow rate. International Journal of Oral and Maxillofacial Surgery, Copenhagen, v. 38, n. 4, p. 316-320, 2009.

LARROSA, F.; IDÍGORA, A.; AGUILAR, F.; RIERA, L.; MARTÍ, M. J.; VALLS, J. Results of using botulism toxin in the treatment of spasmodic dysphonia. Acta Otorrinolaringológica Española, Barcelona, v. 53, n. 1, p. 27-31, 2002.

LEE, S. Y.; SEO, H. G.; PAIK, N. Botulinum toxin injection for dysphagia: a blinded retrospective videofluoroscopic swallowing study analysis. American Journal of Physical Medicine and Rehabilitation, Baltimore, v. 88, n. 6, p. 491-494, 2009.

LEES, A. J.; TURJANSKI, N.; RIVEST, J.; WHURR, R.; LORCH, M.; BROOKES, G. Treatment of cervical dystonia hand spasms and laryngeal dystonia with botulinum toxin. Journal of Neurology, Berlin, v. 239, n. 1, p. 1-4, 1992.

LOGEMANN, J. A.; BOSHES, B.; BLONSKY, E. R.; FISHER, H. B. Speech and swallowing evaluation in the differential diagnosis of neurological disease. Neurología, Neurocirugía, Psiquiatría, México, v. 18, n. 2, 3, p. 71-78, 1997.

LUDLOW, C. L. Spasmodic dysphonia: a laryngeal control disorder specific to speech. Journal of Neuroscience, Baltimore, v. 31, n. 3, p. 793-797, 2011.

LUDLOW, C. L. Treatment for spasmodic dysphonia: limitations of current approaches. Current Opinion in Otolaryngology \& Head and Neck Surgery, Philadelphia, v. 17, n. 3, p. 160-165, 2009.

MICHELOTTI, A.; SILVA, R.; PADUANO, S.; CIMINO, R.; FARELLA, M. Oromandibular dystonia and hormonal factors: twelve years follow-up of a case report. Journal of Oral Rehabilitation, Oxford, v. 36, n. 12, p. 916-921, 2009.

MOORE, P.; NAUMANN, M. Handbook of botulinum toxin treatment. 2nd ed. Oxford: Blackwell Science, 2003.

MÜNCHAU, A.; GOOD, C. D.; MCGOWAN, S.; QUINN, N. P.; PALMER, J. D.; BHATIA, N. K. P. Prospective study of swallowing function in patients with cervical dystonia undergoing selective peripheral denervation. Journal of Neurology, Neurosurgery, and Psychiatry, London, v. 71, n. 1, p. 67-72, 2001. 
NÓBREGA, A. C.; RODRIGUES, B.; MELO, A. Does botulinum toxin injection in parotid glands interfere with the swallowing dynamics of Parkinson's disease patients? Clinical Neurology and Neurosurgery, Amsterdam, v. 111, n. 5, p. 430432, 2009.

NÚÑEZ, B. F.; díAZ, M. J. P.; COSTALES, M. M.; MORENO, G. C.; SUÁREZ, N. Neurolaringology. Acta Otorrinolaringológica Española, Barcelona, v. 63, n. 2, p. 132-40, 2012.

PEREIRA, J. S. Distonias. Revista Hospital Universitário Pedro Ernesto,Rio de Janeiro, v. 9, n. 1, p. 39-46, 2010.

QUAGLIATO, E. M.; CARELLI, E. F.; VIANA, M. A. A prospective, randomized, double-blind study comparing the efficacy and safety of type a botulinum toxins botox and prosigne in the treatment of cervical dystonia. Clinical Neuropharmacology, New York, v. 33, n. 1, p, 22-26, 2010.

RESTIVO, D. A.; MARCHESE-RAGONA, R.; LAURIA, G.; SQUATRITO, S.; GULLO, D.; VIGNERI, R. Botulinum toxin treatment for oropharyngeal dysphagia associated with diabetic neuropathy. Diabetes Care, New York, v. 29, n. 12, p. 2650-2653, 2006.

RESTIVO, D. A.; MARCHESE-RAGONA, R.; PATTI, F.; SOLARO, C.; MAIMONE, D.; ZAPPALÁ, G.; PAVONE, A. Botulinum toxin improves dysphagia associated with multiple sclerosis. European Journal of Neurology, Oxford, v. 18, n. 3, p. 486-490, 2011.

RISKI, J. E.; HORNER, J.; NASHOLD, B. S. JR. Swallowing function in patients with spasmodic torticollis. Neurology, Hagerstown, v. 40, n. 9, p. 1443-1445, 1990.

ROSAS, M. J.; SÁ, M. J. Distonias laringeas e oro-mandibular: revisão e tratamento. Revista da Faculdade de Ciencias da Saúde, São Paulo, v. 4, n. 4, p. 192-196, 2007.

RUGIU, M. G. Role of videofluoroscopy in evaluation of neurologic dysphagia. Acta Otorhinolaryngologica Italica, Pisa, v. 27, n. 6, p. 306-316, 2007.

SANTOS, V. J.; MATTIOLI, F. M.; MATTIOLI, W. M.; DANIEL, R. J.; CRUZ, V. P. Laryngeal dystonia: case report and treatment with botulinum toxin. Brazilian Journal of Otorhinolaryngology, São Paulo, v. 72, n. 3, p. 425-427, 2006. 
SATALOFF, R. T.; MANDEL, S.; MANN, E. A.; LUDLOW, C. L. Practice parameter: laryngeal electromyography (an evidence-based review). Otolaryngology-Head and Neck Surgery, Rochester, v. 130, n. 6, p. 770-779, 2004.

SCHLOTTHAUER, G.; TORRES, M. E.; JACKSON-MENALDI, M. C. A pattern recognition approach to spasmodic dysphonia and muscle tension dysphonia automatic classification. Journal of Voice, New York, , v. 24, n. 3, p. 346-353, 2010.

SCHWEINFURTH, J. M.; BILLANTE, M.; COUREY, M. S. Risk factors and demographics in patients with spasmodic dysphonia. Laryngoscope, St. Louis, v. 112, n. 2, p. 220-223, 2002.

SPADOTTO, A. A.; GATTO, A. R.; COLA, P. C.; MONTAGNOLI, A. N.; SCHELP, A. O.; SILVA, R. G.; YAMASHITA, S.; PEREIRA, J. C.; HENRY, M. A. C. A. Software para análise quantitativa da deglutição. Radiologia Brasileira, São Paulo, v. 41, n. 1, p. 25-28, 2008.

SPOSITO, M. M. M. Toxina botulínica do tipo A: mecanismo de ação. Acta Fisiátrica, São Paulo, v. 16, n. 1, p. 25-37, 2009.

STONG, B. C.; DELGAUDIO, J. M.; HAPNER, E. R.; JOHNS, M. M. Safety of simultaneous bilateral botulinum toxin injections for abductor spasmodic dysphonia. Archives of Otolaryngology-Head \& Neck Surgery, Chicago, v. 131, n. 9, p. 793795, 2005.

SVETEL, M.; VASIĆ, M.; TOMIĆ, G.; STANKOVIĆ, P.; STOJANOVIĆ, M.; DRAGASEVIĆ, N.; DERGENC, R.; VUKASINOVIĆ, M.; PEKMEZOVIĆ, T.; PETROVIĆ, I.; KOSTIĆ, V. Botulinum toxin efficacy in the treatment of patients with spasmodic dysphonia. Vojnosanitetski Pregled, Belgrade, v. 64, n. 10, p. 671-675, 2007.

SULICA, L.; LOUIS, E. D. Clinical characteristics of essential voice tremor: a study of 34 cases. Laryngoscope, St. Louis, v. 120, n. 3, p. 516-528, 2010.

THOMAS, J. P.; SIUPSINSKIENE, N. Frozen versus fresh reconstituted botox for laryngeal dystonia. Otolaryngology-Head and Neck Surgery, Rochester, v. 135, n. 2, p. 204-208, 2006.

TORRES-RUSSOTTO, D.; PERLMUTTER, J. S. Task-specific dystonias. Annals of the New York Academy of Sciences, New York, v. 1142, n. 10, p. 179-199, 2008. 
UPILE, T.; ELMIYEH, B.; JERJES, W.; PRASAD, V.; KAFAS, P.; ABIOLA, J.; YOUL, B.; EPSTEIN, R.; HOPPER, C.; SUDHOFF, H.; RUBIN, J. Unilateral versus bilateral thyroarytenoid botulinum toxin injections in adductor spasmodic dysphonia: a prospective study. Head \& Face Medicine, London, v. 5, n.20, p. 01-11, 2009.

VALE-PRODOMO, L. P. Caracterização videofluoroscópica da fase faríngea da deglutição. 2012. 95 f. Tese (Doutorado) - Fundação Antônio Prudente, São Paulo, 2010.

VASCONCELOS, S.; BIRKENT, H.; SARDESAI, M. G.; MERATI, A. L.; HILLEL, A. D. Influência da idade e gênero na dose e eficácia da toxina botulínica para distonia laríngea. Laryngoscope, St. Louis, v. 119, n. 10, p. 2004-2007, 2009.

VILANOVA, T. A. Avaliação videofluoroscópica da deglutição pré e pósaplicação de toxina botulínica em indivíduos com distonia cervical. 2007. Dissertação (Mestrado) - Universidade Federal de São Paulo, São Paulo, 2007.

WATTS, C. R.; NYE, C.; WHURR, R. Botulinum toxin for treating spasmodic dysphonia (laryngeal dystonia): a systematic cochrane review. Clinical Rehabilitation, London, v. 20, n. 2, p. 112-122, 2006.

WATTS, C. R.; TRUONG, D. D.; NYE, C. Evidence for the effectiveness of botulinum toxin for spasmodic dysphonia from high-quality research designs. Journal of Neural Transmission, Austria, v. 115, n. 4, p. 625-630, 2008.

ZARZUR, A. P.; SHINZATO, G. Laryngeal electromyography: basic principles and new practical applications. Acta Otorrinolaringológica, Barcelona, v. 25, n. 1, p. 04$11,2007$. 


\section{ANEXOS \\ Anexo - A \\ Termo de Consentimento Livre e Esclarecido}

Pacientes

O senhor (a) está sendo convidado (a) a participar do estudo científico "Estudo da Deglutição em Pacientes com Distonia Laríngea antes e depois do Tratamento com Toxina Botulínica", onde o senhor (a) será submetido a um exame chamado videofluoroscopia.

O objetivo deste estudo será avaliar as consequências da sua doença e do tratamento na sua maneira de engolir. É possível que a sua doença cause alguma alteração durante a alimentação.

A videofluoroscopia será realizada no setor de Radiologia do HCFMRP-USP, antes e 30 dias após a injeção de toxina botulínica, utilizada no tratamento do seu problema. O exame será realizado com o senhor (a) sentado em uma cadeira.

Durante a realização do exame o senhor (a) irá engolir 6 vezes a quantidade de $5 \mathrm{~mL}$, sendo 3 na consistência líquida, com o uso do material usado em radiografias, sulfato de bário, que será oferecido com o auxílio de uma seringa, que será posicionada em sua boca pela pesquisadora, e 3 na consistência pastosa, que será obtida com a mistura de $3 \mathrm{~g}$ do engrossante de alimentos Nutilis em $50 \mathrm{~mL}$ de sulfato de bário líquido, que será oferecida em uma colher posicionada em sua boca pela pesquisadora.

Será mantido total sigilo sobre sua identidade e em qualquer momento o senhor (a) poderá desistir da sua participação na pesquisa, sem quaisquer despesas ou interferências no tratamento de sua doença. Qualquer dúvida a respeito do estudo será esclarecida pelos pesquisadores. A radiografia não causará riscos a sua 
pessoa e esperamos com os resultados conhecer melhor o efeito da distonia laríngea no ato de engolir e falar.

Os pesquisadores são responsáveis pelo que ocorrer durante a pesquisa. Não haverá despesa com a sua participação, mas caso ela ocorra será de responsabilidade dos pesquisadores.

Concordo em participar da pesquisa "Estudo da Deglutição em Pacientes com Distonia Laríngea antes e depois do Tratamento com Toxina Botulínica”.

PARTICIPANTE DA PESQUISA OU REPONSÁVEL.

Nome:

Prof. Dr. Roberto Oliveira Dantas

Tel: (16) 36022457

CRM: 17430
Fga. Leda Maria Tavares Alves

Tel: (16) 36022457

CRFa: 10477 


\section{Anexo - B \\ Termo de Consentimento Livre e Esclarecido}

Controles

O senhor (a) está sendo convidado (a) a participar do estudo científico "Estudo da Deglutição em Pacientes com Distonia Laríngea antes e depois do Tratamento com Toxina Botulínica", onde o senhor (a) será submetido a um exame chamado videofluoroscopia.

Como o senhor (a) é uma pessoa normal, os resultados do seu exame serão comparados com aqueles de doentes com Distonia Laríngea.

O objetivo deste estudo será avaliar as consequências da doença e do tratamento na maneira de engolir.

A videofluoroscopia será realizada no setor de Radiologia do HCFMRP-USP, com o senhor (a) sentado em uma cadeira.

Durante a realização do exame o senhor (a) irá engolir 6 vezes a quantidade de $5 \mathrm{~mL}$, sendo 3 na consistência líquida, com o uso do material usado em radiografias, sulfato de bário, que será oferecido com o auxílio de uma seringa, que será posicionada em sua boca pela pesquisadora, e 3 na consistência pastosa, que será obtida com a mistura de $3 \mathrm{~g}$ do engrossante de alimentos Nutilis em $50 \mathrm{~mL}$ de sulfato de bário líquido, que será oferecida em uma colher posicionada em sua boca pela pesquisadora.

Será mantido total sigilo sobre sua identidade e em qualquer momento o senhor (a) poderá desistir da sua participação na pesquisa, sem quaisquer despesas. Qualquer dúvida a respeito do estudo será esclarecida pelos pesquisadores. A radiografia não causará riscos a sua pessoa e esperamos com os resultados conhecer melhor o efeito da distonia laríngea no ato de engolir. 
Os pesquisadores são responsáveis pelo que ocorrer durante a pesquisa. Não haverá despesa com a sua participação, mas caso ela ocorra será de responsabilidade dos pesquisadores.

Concordo em participar da pesquisa "Estudo da Deglutição em Pacientes com Distonia Laríngea antes e depois do Tratamento com Toxina Botulínica”.

PARTICIPANTE DA PESQUISA OU REPONSÁVEL

Nome:

Prof. Dr. Roberto Oliveira Dantas

Tel: (16) 36022457

CRM: 17430
Fga. Leda Maria Tavares Alves

Tel: (16) 36022457

CRFa: 10477 
Anexo - C

\section{Aprovação do Comitê de Ética em Pesquisa}

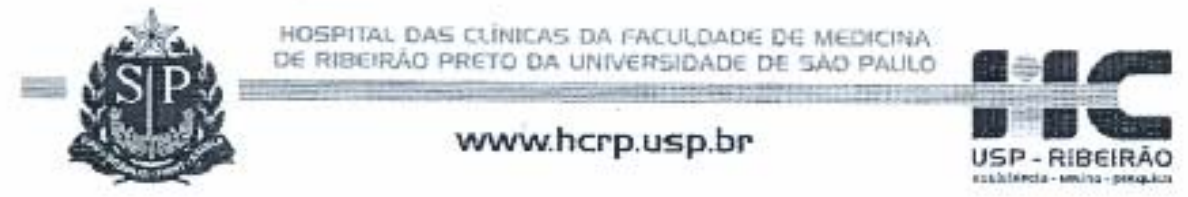

Ribeirâo Preto, 31 de marẹo de 2010

Oficio $\mathrm{n}^{\circ} \mathrm{9} 20 / 2010$

$\mathrm{CEP} / \mathrm{MGV}$

Prezados Senhores,

O trabalho intitulado "EsTuDo DA DEGLUTIÇÅo E DA VOZ EM PACIENTES COM DISTONIA ESPÁSTICA ANTES E DEPOIS DO TRATAMENTO COM TOXINA BOTULINICA" foi arıalisado pelo Comitê de Ética em Pesquisa, em sua 304" Reuniào Ordinária rcalizada em 29/03/2010 e enquadrado na categoria: APROVADO, bem como o Termo de Consentimento Livre e Esclarecido, de acordo com o Processo HCRP $\mathrm{n}^{\circ} 13687 / 2009$.

Este Comité segne integralmente a Conferencia Intemacional de Harmonizaçao de Boas Praticas Clinicus (1GH-GCP), bem como a Resolução ñ $196 / 96$ CNS/MS.

Lembramos que devem ser apresentados a este CEP, o Relatório Parcial e o Relatório Final da pesquisa.

Atcnciosamente.

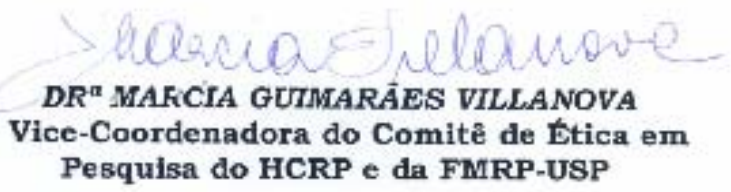

Ilustríssimos Senhores

LEDA MARIA TAVARES ALVES

PROF. DR. ROBERTO OLIVEIRA DANTAS (Orientador)

Depto. de Clínica Médica

\footnotetext{
Comite de Etica em Posquira HCRP e FMRP-USP - Campus Universitario

FWA - 00702733 ; IRB - 00002186 e Registro SISNEP/CONEP $n^{\circ} 4$

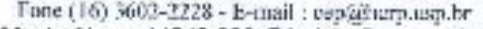

Monte Alegre 14048-\$00 R beirso Preto SP
} 
Anexo - D

Análise Videofluoroscópica Qualitativa

Nome:

Idade:

Data:

Pré-Aplicação ( )

Pós-Aplicação ( )

Controle ( )

\begin{tabular}{|c|c|c|}
\hline & Líquido & Pastoso \\
\hline \multicolumn{3}{|l|}{ Penetração } \\
\hline \multicolumn{3}{|l|}{ Aspiração } \\
\hline \multicolumn{3}{|l|}{$\begin{array}{l}\text { Sobra de } \\
\text { Resíduos }\end{array}$} \\
\hline \multicolumn{3}{|l|}{ Escape } \\
\hline \multirow[t]{2}{*}{$\begin{array}{l}\text { Número de } \\
\text { Deglutições }\end{array}$} & & \\
\hline & & \\
\hline
\end{tabular}


Anexo-E

Análise Videofluoroscópica Quantitativa

Nome:

Idade:

Data:

CONTROLE ( )

PRÈ-APLIC. ( ）

PÓS-APLIC. ( ）

Dias

\begin{tabular}{|c|c|c|c|c|c|c|}
\hline \multirow[t]{2}{*}{ Tempos } & \multicolumn{3}{|c|}{ Líquido } & \multicolumn{3}{|c|}{ Pastoso } \\
\hline & $5 \mathrm{ml}$ & $5 \mathrm{ml}$ & $5 \mathrm{ml}$ & $5 \mathrm{ml}$ & $5 \mathrm{ml}$ & $5 \mathrm{ml}$ \\
\hline TDPO & & & & & & \\
\hline TTO & & & & & & \\
\hline TTF & & & & & & \\
\hline TCF & & & & & & \\
\hline TTEES & & & & & & \\
\hline TMH & & & & & & \\
\hline IMH / IFF & & & & & & \\
\hline TOFE & & & & & & \\
\hline TCF-TMH & & & & & & \\
\hline
\end{tabular}




\section{Anexo - F \\ Anamnese Fonoaudiológica}

(Pré-Aplicação)

Nome:

Idade:

Sexo:

Registro:

Profissão:

Escolaridade:

Diagnóstico:

Data:

Hora:

\section{Anamnese:}

Esta grávida ou menstruada no momento:

( ) Sim ( ) Não

Período:

Hábito de fumar:

( ) Sim ( ) Não

Período:

Hábito de ingerir bebidas alcoólicas:
( ) Sim
( ) Não

Período:

Queixa de Disfagia:
( ) $\mathrm{Sim}$
( ) Não
( ) Líquido
( ) Pastoso
( ) Sólido

Frequência nos últimos 30 dias: 
Durante Alimentação apresenta:
tosse
( ) $\operatorname{Sim}$
( ) Não
engasgo
( ) Sim
( ) Não

outros

Videofluoroscopia: 
Anexo-G

\section{Anamnese Fonoaudiológica}

(Pós-Aplicação)

Nome:

Idade:

DN:

Sexo:

Registro:

Profissão:

Escolaridade:

Diagnóstico:

Data:

Hora:

\section{Anamnese:}

Esta grávida ou menstruada no momento:

( ) Sim ( ) Não

Período:

Hábito de fumar:

( ) Sim ( ) Não

Período:

Hábito de ingerir bebidas alcoólicas:
( ) Sim
( ) Não

Período:

Queixa de Disfagia:
( ) Sim ( ) Não
( ) Líquido ( ) Pastoso ( ) Sólido

Frequência nos últimos 30 dias: 
Durante Alimentação apresenta:
tosse
( ) Sim
( ) Não
engasgo
( ) Sim
( ) Não

outros

Videofluoroscopia: 


\section{Anexo - H}

\section{Quadro de Resultados Diagnósticos, Qualitativos e Queixas dos Pacientes com Distonia Laríngea}

\begin{tabular}{|c|c|c|c|}
\hline Pacientes & Diagnóstico & Pré - Aplicação & Pós - Aplicação \\
\hline $\begin{array}{c}\text { GRS } \\
49 \text { anos }\end{array}$ & Distonia Laríngea & $\begin{array}{l}\text { Presença de resíduos em } \\
\text { região oral e valécula, e } \\
\text { presença de mais de uma } \\
\text { deglutição para as } \\
\text { consistências líquida e } \\
\text { pastosa. }\end{array}$ & $\begin{array}{l}\text { Presença de resíduos em região } \\
\text { oral e valécula, presença de } \\
\text { escape para consistência pastosa } \\
\text { e presença de mais de uma } \\
\text { deglutição para as consistências } \\
\text { líquida e pastosa. }\end{array}$ \\
\hline $\begin{array}{c}\text { MMPT } \\
55 \text { anos }\end{array}$ & $\begin{array}{c}\text { Distonia } \\
\text { Generalizada }\end{array}$ & $\begin{array}{l}\text { Referiu queixa de disfagia, } \\
\text { presença de resíduos em } \\
\text { região oral, valécula e seios } \\
\text { piriformes, apresentou escape } \\
\text { do bolo para as consistências } \\
\text { líquida e pastosa, e presença } \\
\text { de mais de uma deglutição } \\
\text { para as duas consistências. }\end{array}$ & $\begin{array}{l}\text { Referiu queixa de disfagia, } \\
\text { presença de resíduos em região } \\
\text { oral, valécula e seios piriformes, } \\
\text { apresentou escape do bolo para as } \\
\text { consistências líquida e pastosa, e } \\
\text { apresentou mais de uma } \\
\text { deglutição para os bolos nas duas } \\
\text { consistências. }\end{array}$ \\
\hline $\begin{array}{c}\text { AAD } \\
88 \text { anos }\end{array}$ & $\begin{array}{l}\text { Blefaroespasmo, } \\
\text { Distonia Cervical, } \\
\text { Distonia Laríngea }\end{array}$ & $\begin{array}{c}\text { Presença de resíduo em } \\
\text { valécula e elevação de laringe } \\
\text { ineficiente para a retirada dos } \\
\text { resíduos. }\end{array}$ & $\begin{array}{c}\text { Presença de resíduos em valécula } \\
\text { e seios piriformes e } \\
\text { diminuição da elevação laríngea. }\end{array}$ \\
\hline $\begin{array}{c}\text { OMJ } \\
56 \text { anos }\end{array}$ & Distonia Laríngea & $\begin{array}{l}\text { Referiu queixa de disfagia, } \\
\text { presença de resíduos em } \\
\text { região oral, valéculas e seios } \\
\text { piriformes e presença de mais } \\
\text { de uma deglutição para } \\
\text { consistência pastosa. }\end{array}$ & $\begin{array}{l}\text { Presença de resíduos em região } \\
\text { oral, valéculas e seios piriformes, e } \\
\text { presença de mais de uma } \\
\text { deglutição para as consistências } \\
\text { líquida e pastosa. }\end{array}$ \\
\hline $\begin{array}{c}\text { JE } \\
79 \text { anos }\end{array}$ & Distonia Laríngea & $\begin{array}{l}\text { Presença de resíduos em } \\
\text { região oral e valéculas e } \\
\text { escape dos bolos. }\end{array}$ & $\begin{array}{l}\text { Presença de escape dos bolos, } \\
\text { presença de resíduos em região } \\
\text { oral, valéculas e maior quantidade } \\
\text { em seios piriformes, e presença de } \\
\text { mais de uma deglutição para } \\
\text { consistência líquida. }\end{array}$ \\
\hline $\begin{array}{l}\text { LCJP } \\
33 \text { anos }\end{array}$ & $\begin{array}{c}\text { Ataxia } \\
\text { Apendicular, } \\
\text { Distonia Laríngea }\end{array}$ & $\begin{array}{l}\text { Postura de cabeça para traz, } \\
\text { presença de resíduos em } \\
\text { valéculas, seios piriformes, } \\
\text { elevação de laringe ineficiente. }\end{array}$ & $\begin{array}{c}\text { Postura de cabeça para traz, } \\
\text { elevação de laringe ineficiente, } \\
\text { presença de resíduos em valéculas } \\
\text { e seios piriformes. }\end{array}$ \\
\hline $\begin{array}{c}\text { HHG } \\
70 \text { anos }\end{array}$ & Tremor Vocal, & Presença de resíduos em & Presença de resíduos em região \\
\hline
\end{tabular}




\begin{tabular}{|c|c|c|c|}
\hline & Distonia Laríngea & $\begin{array}{c}\text { região oral e valéculas, } \\
\text { presença de escape para a } \\
\text { consistência pastosa, } \\
\text { presença de mais de uma } \\
\text { deglutição para a consistência } \\
\text { líquida. }\end{array}$ & $\begin{array}{c}\text { oral e valéculas, presença de } \\
\text { escape para as consistências } \\
\text { líquida e pastosa, e presença de } \\
\text { mais de uma deglutição para a } \\
\text { consistência líquida. }\end{array}$ \\
\hline $\begin{array}{c}\text { RAC } \\
81 \text { anos }\end{array}$ & $\begin{array}{c}\text { Disfonia } \\
\text { Psicogênica, } \\
\text { Distonia Laríngea }\end{array}$ & $\begin{array}{c}\text { Referiu queixa de disfagia, } \\
\text { apresentou presença de } \\
\text { resíduos em região oral e } \\
\text { valécula, apresentou escape } \\
\text { do bolo para as consistências } \\
\text { líquida e pastosa, e } \\
\text { apresentou mais de uma } \\
\text { deglutição para as duas } \\
\text { consistências. }\end{array}$ & $\begin{array}{c}\text { Presença de resíduos em região } \\
\text { oral e valéculas, e presença de } \\
\text { mais de uma deglutição para as } \\
\text { duas consistências. }\end{array}$ \\
\hline $\begin{array}{c}\text { MIRM } \\
52 \text { anos }\end{array}$ & Distonia Laríngea & $\begin{array}{l}\text { Presença de resíduos em } \\
\text { região oral e valéculas, e } \\
\text { presença de mais de uma } \\
\text { deglutição para o bolo nas } \\
\text { consistências líquida e } \\
\text { pastosa. }\end{array}$ & $\begin{array}{l}\text { Referiu queixa de disfagia, } \\
\text { presença de resíduos em região } \\
\text { oral e valécula, presença de } \\
\text { escape para a consistência líquida } \\
\text { e de mais de uma deglutição para } \\
\text { as consistências líquida e pastosa. }\end{array}$ \\
\hline $\begin{array}{c}\text { MSP } \\
81 \text { anos }\end{array}$ & Distonia Laríngea & $\begin{array}{l}\text { Referiu queixa de disfagia, } \\
\text { posicionou cabeça para traz, } \\
\text { apresentou escape e presença } \\
\text { de mais de uma deglutição } \\
\text { para as duas consistências. }\end{array}$ & $\begin{array}{c}\text { Referiu queixa de disfagia, } \\
\text { presença de resíduo em região } \\
\text { oral, valécula e seios piriformes, } \\
\text { presença de escape do bolo para a } \\
\text { consistência pastosa, e presença } \\
\text { de mais de uma deglutição para as } \\
\text { duas consistências. }\end{array}$ \\
\hline $\begin{array}{c}\text { JCSF } \\
23 \text { anos }\end{array}$ & $\begin{array}{c}\text { Distonia } \\
\text { Generalizada, } \\
\text { Distonia Laríngea }\end{array}$ & $\begin{array}{l}\text { Referiu queixa de disfagia, } \\
\text { posicionou cabeça p/ traz, } \\
\text { presença de penetração, } \\
\text { escape, e mais de uma } \\
\text { deglutição para as duas } \\
\text { consistências. }\end{array}$ & $\begin{array}{c}\text { Presença de resíduos em região } \\
\text { oral, valécula e seios piriformes, } \\
\text { presença de elevação laríngea } \\
\text { ineficiente, posicionou cabeça p/ } \\
\text { traz, presença de escape para a } \\
\text { consistência líquida e mais de uma } \\
\text { deglutição para as duas } \\
\text { consistências. }\end{array}$ \\
\hline $\begin{array}{c}\text { JG } \\
42 \text { anos }\end{array}$ & $\begin{array}{c}\text { Distonia } \\
\text { Orofaríngea } \\
\text { (cervical), } \\
\text { Blefaroespasmo }\end{array}$ & $\begin{array}{l}\text { Presença de resíduos em } \\
\text { região oral e valécula, } \\
\text { posicionou cabeça p/ traz, } \\
\text { presença de escape do bolo } \\
\text { para as consistências líquida e } \\
\text { pastosa, e presença de mais } \\
\text { de uma deglutição para as }\end{array}$ & $\begin{array}{c}\text { Presença de resíduos em região } \\
\text { oral e valécula, elevação de laringe } \\
\text { ineficiente, presença de escape do } \\
\text { bolo para as consistências líquida } \\
\text { e pastosa, e presença de mais de } \\
\text { uma deglutição para as duas } \\
\text { consistências. }\end{array}$ \\
\hline
\end{tabular}




\begin{tabular}{|c|c|c|c|}
\hline & & duas consistências. & \\
\hline $\begin{array}{c}\text { KAP } \\
31 \text { anos }\end{array}$ & $\begin{array}{c}\text { Distonia } \\
\text { Generalizada, } \\
\text { Distonia Laríngea }\end{array}$ & $\begin{array}{l}\text { Posicionou cabeça p/ frente, } \\
\text { presença de resíduos em } \\
\text { região oral, valécula e seios } \\
\text { piriformes, presença de } \\
\text { escape do bolo para as } \\
\text { consistências líquida e } \\
\text { pastosa, e elevação laríngea } \\
\text { ineficiente. }\end{array}$ & $\begin{array}{l}\text { Presença de resíduos em região } \\
\text { oral, valécula e seios piriformes, } \\
\text { elevação laríngea ineficiente, } \\
\text { presença de escape do bolo para a } \\
\text { consistência líquida, e presença de } \\
\text { mais de uma deglutição para as } \\
\text { duas consistências. }\end{array}$ \\
\hline $\begin{array}{l}\text { MJSM } \\
63 \text { anos }\end{array}$ & $\begin{array}{l}\text { Tremor região } \\
\text { cefálica, Distonia } \\
\text { Cervical - } \\
\text { Orofacial e } \\
\text { Laríngea, } \\
\text { Blefaroespasmos }\end{array}$ & $\begin{array}{l}\text { Presença de resíduos em } \\
\text { região oral e valécula, } \\
\text { posicionou cabeça p/ traz, } \\
\text { presença de escape para as } \\
\text { consistências líquida e } \\
\text { pastosa, apresentou mais de } \\
\text { uma deglutição para as duas } \\
\text { consistências. }\end{array}$ & $\begin{array}{c}\text { Presença de resíduos em região } \\
\text { oral e valécula, presença de } \\
\text { escape do bolo para as } \\
\text { consistências líquida e pastosa, e } \\
\text { presença de mais de uma } \\
\text { deglutição para as duas } \\
\text { consistências. }\end{array}$ \\
\hline $\begin{array}{c}\text { LBM } \\
63 \text { anos }\end{array}$ & $\begin{array}{c}\text { Tremor mão } \\
\text { direita, } \\
\text { Movimentos } \\
\text { coroatetóides } \\
\text { Membros } \\
\text { superiores, } \\
\text { Distonia } \\
\text { Laríngea, Tremor } \\
\text { Oromandibular }\end{array}$ & $\begin{array}{c}\text { Referiu queixa de disfagia, } \\
\text { presença de resíduos em } \\
\text { região oral, valécula, e seios } \\
\text { piriformes, com maior } \\
\text { quantidade em todas as } \\
\text { deglutições na valécula, } \\
\text { presença de mais de uma } \\
\text { deglutição para as } \\
\text { consistências líquida e } \\
\text { pastosa. }\end{array}$ & $\begin{array}{l}\text { Presença de resíduos em região } \\
\text { oral, valécula e seios piriformes em } \\
\text { menor quantidade, e presença de } \\
\text { mais de uma deglutição para as } \\
\text { consistências líquida e pastosa. }\end{array}$ \\
\hline $\begin{array}{c}\text { DFFL } \\
75 \text { anos }\end{array}$ & $\begin{array}{l}\text { Blefaroespasmo, } \\
\text { Distonia Cervical, } \\
\text { Distonia Laríngea }\end{array}$ & $\begin{array}{l}\text { Posicionou cabeça p/ traz, } \\
\text { elevação laríngea ineficiente, } \\
\text { presença de resíduos em } \\
\text { região oral e valécula, e } \\
\text { presença de mais de uma } \\
\text { deglutição para as } \\
\text { consistências líquida e } \\
\text { pastosa. }\end{array}$ & $\begin{array}{l}\text { Apresentou queixa disfagia, } \\
\text { presença de resíduos em região } \\
\text { oral e valécula, e apresentou mais } \\
\text { de uma deglutição para as } \\
\text { consistências líquida e pastosa. }\end{array}$ \\
\hline $\begin{array}{l}\text { TFVD } \\
47 \text { anos }\end{array}$ & $\begin{array}{l}\text { Distonia Cervical, } \\
\text { Distonia Laríngea }\end{array}$ & $\begin{array}{c}\text { Presença de resíduos em } \\
\text { região oral, valécula e seios } \\
\text { piriformes, presença de } \\
\text { escape do bolo para a } \\
\text { consistência líquida, e } \\
\text { presença de mais de uma } \\
\text { deglutição para a consistência } \\
\text { líquida. }\end{array}$ & $\begin{array}{c}\text { Presença de resíduo em região } \\
\text { oral, valécula e seios piriformes, } \\
\text { presença de escape do bolo para } \\
\text { as consistências líquida e pastosa, } \\
\text { presença de mais de uma } \\
\text { deglutição para as duas } \\
\text { consistências. }\end{array}$ \\
\hline
\end{tabular}




\title{
ESTUDO DA DEGLUTIÇÃO EM PACIENTES COM DISTONIA LARÍNGEA ANTES E APÓS O TRATAMENTO COM TOXINA BOTULÍNICA
}

\author{
Leda Maria Tavares Alves, Hilton Marcos Alves Ricz, \\ Lilian \\ Neto Aguiar Ricz, Roberto Oliveira Dantas \\ Faculdade de Medicina de Ribeirão Preto - Universidade de São Paulo
}

\begin{abstract}
Resumo
A distonia é uma síndrome que consiste de contrações musculares involuntárias que resultam em movimentos distorcidos e repetitivos e/ou posturas anormais. $\mathrm{O}$ tratamento pode ser por farmacoterapia, com drogas anticolinérgicas ou com a injeção de toxina botulínica no grupo de músculos afetados. O objetivo do trabalho foi avaliar a deglutição nos pacientes com distonia laríngea, antes e após o tratamento com a toxina botulínica. Nossa hipótese foi que a toxina botulínica modificaria a deglutição dos pacientes com distonia laríngea. Foram avaliados 17 indivíduos adultos, acima de 18 anos de idade, com diagnóstico clínico de distonia laríngea antes e após o tratamento com o uso de toxina botulínica do tipo A, e 20 indivíduos adultos saudáveis como controles. Os participantes foram submetidos à anamnese fonoaudiológica e avaliação videofluoroscópica da deglutição. Os pacientes com distonia foram avaliados antes e 30 dias após a injeção de toxina botulínica, guiada por eletromiografia. $\mathrm{Na}$ videofluoroscopia foram avaliadas 6 deglutições de $5 \mathrm{~mL}$, sendo 3 na consistência líquida (sulfato de bário $100 \%$, e 3 na consistência pastosa ( $3 \mathrm{~g}$ do espessante alimentar ThickenUp Clear, em $50 \mathrm{~mL}$ de sulfato de bário $100 \%$ ) oferecidas em uma colher. A ordem das deglutições foi aleatória. Foram estudadas as fases oral e faríngea da deglutição, com registro de 30 quadros por segundo. Os pacientes com distonia laríngea apresentaram aumento de resíduos na região oral e em valécula e maior número de deglutições. Os pacientes apresentaram tempo de trânsito faríngeo (TTF) menor do que os controles $(p<0,01)$, para os bolos nas consistências líquida e pastosa. O TTF foi menor após aplicação do que antes da aplicação da toxina botulínica, quando da deglutição do bolo pastoso. Portanto, concluiu-se que os pacientes com distonia laríngea, comparado a controles, têm trânsito mais rápido pela faringe, aumento de resíduos na região oral e em valécula e maior número de deglutições para o mesmo volume. Trinta dias após a aplicação da toxina botulínica foi observado diminuição da duração do trânsito pela faringe, com o bolo pastoso, e resposta tardia do movimento do osso hióide em relação à chegada do bolo na faringe.
\end{abstract}

Palavras Chaves: Distonia Laríngea, Toxina Botulínica, Deglutição, Videofluoroscopia, Eletromiografia. 


\begin{abstract}
Dystonia is a syndrome consisting of involuntary muscle contractions that result in distorted and repetitive movements and/or abnormal postures. Treatment may be by pharmacotherapy with anticholinergic drugs or with the injection of botulinum toxin in the affected muscle group. The aim of this study was to evaluate swallowing in patients with dystonia before and after treatment with botulinum toxin. Our hypothesis was that botulinum toxin modify the swallowing of patients with spastic dystonia. Seventeen adult subjects over the age of 18 years with clinically diagnosed dystonia were evaluated before and after treatment with botulinum toxin type $A$ and compared to 20 healthy adults as controls. Participants underwent phonologic anamnesis and videofluoroscopy assessment of swallowing. Patients with dystonia were assessed before and 30 days after injection of botulinum toxin, guided by electromyography. In fluoroscopy, 6 swallows were evaluated of $5 \mathrm{ml}: 3$ in a liquid consistency (100\% barium sulfate) and 3 in a pasty consistency ( $3 \mathrm{~g}$ of food thickener, ThickenUp Clear) in $50 \mathrm{~mL}$ of $100 \%$ barium sulfate, offered on a spoon. The oral and pharyngeal phases of swallowing were studied from swallows of random order, with registration of 30 frames per second. Patients with dystonia showed an increase of residue in the oral region and vallecula and greater number of multiple swallows. Patients had less pharyngeal transit time (PTT) than controls $(p<0.01)$ for boluses of liquid and pasty consistencies. PTT was lower after the application of botulinum toxin than before with the swallowing of a pasty bolus. It was concluded that patients with dystonia, compared to controls, have more rapid transit through the pharynx, increased residues in the oral region and vallecula and a greater number of swallows for the same volume. Thirty days after the botulinum toxin, it was observed a shorter pharingeal transit time with paste bolus, and delayed hyoid movement response to bolus presence in pharynx.
\end{abstract}

Keywords: Laryngeal dystonia, Botulinum toxin, Swallowing, Fluoroscopy, Electromyography.

\title{
Introdução
}

Distonia é um distúrbio do movimento, caracterizada por contrações musculares involuntárias sustentadas que levam a movimentos repetitivos e posturas de torção anormais nas áreas afetadas, de múltiplas ou simples (focal) regiões do corpo, incluindo a cabeça, pescoço, face, tronco, braços e pernas (JIMENEZ-SHAHED 2012).

A forma mais comum de distonia é a focal que está presente principalmente em adultos. Essa distonia pode afetar a laringe (disfonia espasmódica), causando uma voz com qualidade tensa e descontínua durante o fechamento involuntário das pregas vocais na fonação (DELONG e JUNCOS, 2005).

A distonia laríngea é um exemplo de um distúrbio focal, de ação induzida que afeta o controle motor da laringe (HO et al. 2011). Existem duas formas de distonia, a adutora e a abdutora. A distonia laríngea adutora é um distúrbio de voz caracterizada por distensão do musculo laringeal, quebra da voz nas vogais 
durante a fala devido à intermitente hiperadução das pregas vocais, resultando em uma qualidade de voz áspera, tensa-estrangulada, com quebras fonatórias, quebras de intensidade, frequencia fundamental baixa e a produção de fala com esforço, e ocorre em aproximadamente $80 \%$ a $90 \%$ dos casos. A distonia laríngea abdutora é relativamente rara e envolve intermitentes faltas de voz durante as quebras vocais, caracterizada pelo aumento intermitente da glote, qualidade de voz soprosa transitória, pela incapacidade de pronunciar as consoantes antes da iniciação das vogais seguintes, e é geralmente considerada como um tipo de distonia laríngea central de ação induzida, e ocorre em aproximadamente $10 \%$ a $20 \%$ dos casos. (LUDLOW 2009; CANNITO et al. 2008; WATTS et al. 2008).

O entendimento da etiologia da distonia laríngea tem evoluído ao longo do tempo a partir de teorias de causas psicológicas subjacentes a opinião atual que enfatiza a causa neurológica primária (WATTS et al. 2008). Alguns autores associam esses distúrbios a doenças psicológicas, neurológicas ou traumáticas (SCHWEINFURTH et al. 2002; JIMENEZ-SHAHED 2012).

O tratamento da distonia laríngea pode ser através da farmacoterapia, com drogas anticolinérgicas, com a injeção de toxina botulínica (BTX) no grupo de músculos afetados, e com método cirúrgico, com rizotomia anterior cervical associada com injeção da BTX (Delong e Juncos, 2005).

A terapia com o uso da toxina botulínica provou, ser altamente eficaz para as perturbações da fala consequentes das contrações distônicas das pregas vocais, com uma melhoria estabelecida em 80 a 100\% dos pacientes (SVETEL et al. 2007).

Os efeitos colaterais vocais são geralmente relacionados à dose da toxina botulínica utilizada e envolve um período de voz "soprosa", disfagia leve, moderada ou grave e, ocasionalmente, de sintomas semelhantes ao de pacientes com virose respiratória. (WATTS et al. 2006).

A complicação mais comum do tratamento, com a aplicação da BTX é a disfagia, encontrada em 14\% de todos os participantes. (JANKOVIC 2004).

O objetivo deste trabalho foi avaliar a deglutição em pacientes com distonia laríngea, antes e após o tratamento com a toxina botulínica.

\section{Metodologia}

Foram avaliados 17 indivíduos adultos acima de 18 anos de idade, com diagnóstico clínico de distonia laríngea antes e após o tratamento com o uso de Toxina Botulínica do tipo A, e 20 indivíduos adultos saudáveis como controles. Os participantes foram submetidos a uma anamnese fonoaudiológica, e avaliação videofluoroscopia da deglutição. Os pacientes com distonia foram avaliados antes e 30 dias após a injeção de toxina botulínica. A aplicação da toxina botulínica foi realizada por meio da introdução de agulha através da membrana cricotireóidea bilateralmente, a $0,5 \mathrm{~cm}$ da linha sagital mediana, 
angulada de $30^{\circ}$ a $45^{\circ}$ lateral e superiormente até a localização do músculo tireoaritenóideo, guiado por eletromiografia. A Anamnese fonoaudiológica foi realizada através de questões apresentadas oralmente, antes da aplicação e 30 dias após a aplicação da toxina botulínica. A duração desta foi de aproximadamente 10 minutos, sendo realizada antes da realização do exame videofluoroscópico. A videofluoroscopia da deglutição foi realizada com a capacitação da imagem em incidência latero-lateral direita pelo aparelho Arcomax Phillips, com o sujeito posicionado verticalmente, sentado em uma cadeira. Foram avaliadas 6 deglutições de $5 \mathrm{~mL}$, sendo 3 na consistência líquida, sulfato de bário (5 mL) (Bariogel ${ }^{\circledR}$ 100\%, Laboratório Cristália, Itapira, São Paulo), com o auxílio de uma seringa, e 3 na consistência pastosa, que foram obtidas com a adição de $3 g$ do espessante alimentar ThickenUp (Nestlé Brasil Ltda.), em $50 \mathrm{~mL}$ de sulfato de bário, e oferecidas em uma colher. A ordem das deglutições foi aleatória. Foram estudadas as fases oral e faríngea da deglutição, com registro de 30 quadros por segundo. As análises estatísticas foram realizadas pelo escritório Proestat - Consultoria Estatística e Pesquisa de Mercado de Ribeirão Preto.

\section{Resultados}

$\mathrm{Na}$ comparação entre os grupos controle e pré-aplicação, para as consistências líquida e pastosa, quanto às variáveis de tempo de preparação oral do bolo, trânsito oral, trânsito faringeo, depuração faríngea, duração do trânsito no esfíncter esofágico superior, duração do movimento do osso hióide e de trânsito orofaríngeo (Tabelas 1 e 2), foi observado que a média do grupo préaplicação para o tempo de trânsito faringeo foi menor do que o grupo controle, para ambas as consistências, demonstrando respectivamente o valor de $\mathrm{p}<0,01 \mathrm{e}$ $\mathrm{p}=0,03$ (Figura 3). Para a consistência pastosa, na comparação entre os grupos controle e pré-aplicação, para os tempos de trânsito oral e tempo do movimento do osso hióide, verificou-se que a média do grupo pré-aplicação, para ambos os tempos, foi maior do que o grupo controle, demonstrando respectivamente os valores de $\mathrm{p}=0,03$ e $\mathrm{p}=0,02$.

Comparando-se o grupo controle com o pós-aplicação, para as consistências líquida e pastosa, verificou-se que o trânsito faringeo, para ambas as consistências, e a duração do trânsito pelo esfíncter superior do esôfago, para a consistência líquida, apresentou uma média menor para o grupo pós-aplicação em relação ao controle, indicando respectivamente os valores de $\mathrm{p}<0,01$ e $\mathrm{p}=0,02$.

Na comparação entre os grupos pré-aplicação e pós-aplicação, para a consistência líquida e pastosa (Tabela 2), observamos que a média do tempo do trânsito faringeo para o grupo pré-aplicação foi maior do que para o pósaplicação, nos indicando o valor de $\mathrm{p}=0,05$. 
Na comparação dos grupos controle, pré e pós-aplicação da toxina botulínica, para as consistências líquida e pastosa, na relação do tempo de depuração faríngea com o tempo do movimento do osso hióide, observamos que não houve diferença significativa na comparação entre os grupos, para ambas as consistências (Tabela 6).

Já na comparação do grupo controle com o pré-aplicação e deste com o pós-aplicação, para a consistência pastosa, para o tempo do transito faringeo, observamos que o valor de $\mathrm{p}$ foi 0,01 para ambas as comparações respectivamente (Tabela 1 ).

Durante a avaliação qualitativa, para as variáveis penetração, aspiração e escape das consistências líquida e pastosa, entre os grupos controle, pré e pósaplicação, podemos constatar que não houve diferença significante na comparação entre os grupos.

Na avaliação qualitativa do resíduo, nas regiões oral, oral e valéculas e oral, valéculas e seios piriformes na consistência líquida, verificou-se que nas comparações dos grupos controle e pré-aplicação houve diferença significativa $(\mathrm{p}=0,04)$, para o resíduo oral (Tabela 3). Já na comparação dos grupos controle e pós-aplicação para a mesma consistência observou-se que, houve diferença significativa $(\mathrm{p}=0,01)$, para as três variáveis.

Durante a avaliação qualitativa do resíduo nas regiões oral, oral e valécula e oral, valécula e seios piriformes (tabela 4), para a consistência pastosa, entre os grupos controle e pós-aplicação, foi constatada que houve uma diferença estatística significativa $(\mathrm{p}=0,01)$.

$\mathrm{Na}$ avaliação do número de deglutições, para a consistência pastosa, na comparação entre os grupos controle e pré-aplicação observou-se, que houve diferença significante com $\mathrm{p}<0,01$ (Tabela 5).

A anamnese fonoaudiológica nas comparações entre os grupos controle e pré-aplicação e entre os grupos pré e pós-aplicação, para as variáveis, hábito de fumar, ingestão de bebidas alcoólicas, queixa de disfagia, tosse e engasgo, não demonstrou nenhuma diferença significativa entre as possíveis comparações.

\section{Discussão}

No presente trabalho, foi realizada a avaliação Videofluoroscópica da deglutição, nos pacientes com distonia laríngea, antes e 30 dias após a aplicação da toxina botulínica, e essa aplicação foi guiada através da eletromiografia.

A videofluoroscopia é considerada o método padrão-ouro no estudo de deglutição e suas disfunções. Videofluoroscopia da deglutição é o processo de gravação de eventos da deglutição dinâmicos usando raios-X e armazenamento de informações em meio magnético. Esse método permite a gravação de alta resolução em tempo real a 30 frames/s, o que permite não só as análises morfológicas, mas também a avaliação fisiológica (COSTA 2010). 
A eletromiografia (EMG) é um exame que avalia o comportamento elétrico e a integridade da unidade motora: o motoneurônio inferior, seu axônio, a placa mioneural e fibra muscular. É considerado exame complementar fundamental em desordens do movimento e extensamente utilizada em Ortopedia e Neurologia. No final da década de 80 e início da de 90, a eletromiografia laríngea (EMGL) foi adicionada ao arsenal de abordagem diagnóstica e terapêutica da laringe e das desordens da voz (ZARZUR e SHINZATO 2007).

Os grupos pré e pós-aplicação apresentaram o tempo de trânsito faringeo menor do que o grupo controle para ambas as consistências avaliadas. Em relação aos tempos de trânsito oral e do movimento do osso hióide, para a consistência pastosa, verificou-se que o grupo pré-aplicação apresentou um tempo maior para ambas as variáveis do que o grupo controle.

O tempo do trânsito faringeo, para ambas as consistências, e a duração do trânsito pelo esfíncter superior do esôfago, para a consistência líquida, apresentaram-se menor para o grupo pós-aplicação em relação ao controle.

Quanto à correlação do tempo de inicio do movimento do hióide com o tempo de início da fase faríngea, verificamos que na comparação entre os controles com os pacientes pós-aplicação, para a consistência líquida, houve diferença significante. Já na comparação do grupo controle com o pré-aplicação e deste com o pós-aplicação, para a consistência pastosa, observamos diferença, para ambas às comparações respectivamente.

Um número maior de pacientes do grupo pós-aplicação e uma quantidade maior de resíduo nas regiões oral, oral e valécula e oral, valécula e seios piriformes foram encontradas para as consistências líquida e pastosa consecutivamente, em relação aos controles. O grupo pré-aplicação apresentou maior número de deglutições do que os controles para a consistência pastosa. $\mathrm{O}$ grupo com distonia laríngea apresentou mais escape durante as deglutições do que os indivíduos do grupo controle.

Os achados deste estudo podem ser caracterizados, pelo fato da consistência líquida exigir um controle maior das estruturas envolvidas na deglutição do que a consistência pastosa e também pela adaptação do paciente em relação ao seu problema, já que o transito oral apresentou-se mais lento, como se fosse uma preparação da consistência a ser deglutida para as fases seguintes. Os estudos a seguir comentam sobre estes achados:

Indivíduos saudáveis de 40 a 60 anos, apresentam local de inicio da fase faríngea abaixo da projeção do ângulo da mandíbula e com o aumento da idade eles tendem a apresentar com mais frequência o inicio da fase faríngea inferior à projeção do ângulo da mandíbula e aumento do tempo de transito faringeo para o volume de 5ml na consistência líquida (PRODOMO 2010).

Neste estudo, tanto os participantes do grupo controle, como os pacientes com distonia laríngea, não demonstraram diferença significativa na correlação entre a depuração faríngea e o movimento do osso hióide, este evento também é referido no estudo abaixo: 
Em investigação videofluoroscópica, com volume de 5ml líquido, realizada em 82 indivíduos saudáveis (média de 58 anos), para determinar o sincronismo entre a localização da cabeça do bolo deglutido, sua relação com o início do movimento do osso hióide no início da deglutição faríngea, verificou-se que 80 \% dos participantes apresentaram o início do movimento hióide e o inicio da fase faríngea da deglutição após a cabeça bolo passar pelo ângulo posterior da mandíbula. Os participantes mais velhos iniciavam o movimento do hióide mais tardiamente. Portanto, estes dados demonstram que um "atraso", por si só, não pode indicar uma deglutição desordenada, sem coexistir deficiências na fisiologia da deglutição (HARRIS 2007).

Os achados obtidos durante a anamnese fonoaudiológica, como queixa de disfagia, em 10 dos 17 pacientes pré-aplicação da toxina botulínica, podem ser pelo fato da distonia laríngea se caracterizar por um grande número de espasmos e a uma incoordenação e enfraquecimento da musculatura envolvida com a deglutição, principalmente se estiver associada a outros tipos de distonia, podendo levar a um maior número de resíduos nas regiões oral, oral e valécula, e oral, valécula e seios piriformes, e maior numero de deglutições. Os estudos a seguir confirmam estes achados:

Os sintomas iniciais das distonias podem incluir uma sensação de aperto/tensão sem dor, fadiga e falta de habilidade com o subsequente desenvolvimento da ativação incontrolável dos músculos que se encontram ao redor com movimentos anormais e altamente qualificados durante uma atividade motora específica (RUSSOTTOA e PERLMUTTERA 2008).

As dificuldades graves de deglutição durante os períodos de espasmos, na distonia laríngea, são caracterizadas por uma tensa constrição ao nível da garganta do sujeito. Uma anormalidade ao nível do músculo cricofaríngeo terá um duplo efeito, tanto sobre as propriedades acústicas da voz quanto na deglutição (ERTEKIN et al. 2002).

Até o término deste estudo, mencionou-se são poucos trabalhos com metodologia semelhante utilizando a avaliação videofluoroscópica. Talvez isto se dê pelo fato da distonia laríngea, geralmente vir acompanhada de outros tipos de distonias, o que dificulta a afirmação mais segura dos achados e também pelo fato da TBX ser um tratamento relativamente recente nos indivíduos com esta dificuldade.

Na comparação entre os grupos, o tempo de trânsito faríngeo foi maior para o grupo pré-aplicação do que para o grupo pós-aplicação, para a consistência pastosa.

A proporção do tempo de depuração faríngea com o tempo do movimento do osso hióide, não demonstrou diferença na comparação entre os grupos, para ambas as consistências.

Observamos que mais pacientes pós-aplicação, apresentaram escape de líquido do que os pré-aplicação. Mais pacientes pré-aplicação, apresentaram penetração e aspiração para a consistência líquida, do que os pacientes pós- 
aplicação. O mesmo número de pacientes, para ambos os grupos, apresentaram penetração e aspiração para a consistência pastosa. Mais pacientes pré-aplicação apresentaram escape para a consistência pastosa do que os pós-aplicação. Estes achados foram constatados, pelo relato de queixa de disfagia em 10 dos 17 pacientes com distonia laríngea. Os achados encontrados neste estudo são confirmados pelos estudos a seguir:

No estudo de pacientes com distonia laríngea que utilizavam toxina botulínica, verificou-se que a presença de disfagia foi encontrada em $37,2 \%$ dos pacientes que realizavam reaplicações da BTX-A, e em $44,2 \%$ dos pacientes que realizavam primeira aplicação da BTX-A. A disfagia apresentou curta duração em ambos os grupos mencionados, demonstrando uma média de 1,4 dias versus 2,4 dias. Os efeitos colaterais da disfagia pós-injeção da toxina, foram semelhantes para os dois tipos de tratamento (THOMAS e SIUPSINSKIENE 2006).

LEE et al.(2009), avaliaram o efeito das injeções da BTX na disfagia acompanhada pela disfunção do ESE e verificaram que após a aplicação os resíduos no seio piriforme diminuíram, e que a injeção da BTX no esfíncter superior do esôfago melhorou a função de deglutição, demonstrando ser uma opção terapêutica possível nestes pacientes.

Os pacientes com distonia laríngea, tratados com injeções de BTX nas cordas vocais, usando uma técnica percutânea sob orientação da EMG, apresentaram melhorias da função vocal normal. Os efeitos adversos foram leves e transitórios. A hipofonia afetou 61,3\% dos pacientes com duração média de 11,3 dias. A disfagia foi relatada em 44,1\% dos casos com duração média de 5,8 dias (LARROSA et al. 2002).

Com o uso da BTX, para o tratamento da distonia laríngea, os espasmos musculares são reduzidos não apenas no músculo injetado, mas também em outros músculos laringeais, e no lado oposto da laringe, o feedback sensorial da laringe é alterado pela redução da compressão da mucosa e redução da pressão subglótica na traquéia devido à redução da hiper adução durante a fala (LUDLOW 2011).

Os efeitos colaterais das injeções nos músculos adutores foram 25\%, com voz sussurrada transitória leve, $10 \%$ com tosse transitória leve durante a deglutição de líquidos, e $<1 \%$ com dor local, hematomas ou prurido. Os efeitos colaterais das injeções nos músculos abdutores foram $2 \%$ dos pacientes com leve esforço respiratório, e $6 \%$ com disfagia transitória leve para sólidos (BLITZER 2010).

Os estudos apresentados relatam a presença de disfagia para diferentes consistências alimentares, fraqueza muscular e tosse, principalmente em pacientes após a aplicação da TBX-A. Neste estudo foi possível verificar que a queixa de disfagia foi referida pelos pacientes, tanto no período pré quanto no pós-aplicação da toxina, ocorrendo com maior frequencia nos pacientes pré- 
aplicação. Este fato pode ter ocorrido em decorrência dos sintomas da própria distonia.

\section{Conclusão}

Os pacientes com distonia laríngea, comparado a controles, têm trânsito mais rápido pela faringe, aumento de resíduos na região oral e em valéculas e maior número de deglutições. Trinta dias após a aplicação da toxina botulínica, em relação aos controles, foi observado aumento de resíduos em boca e faringe e resposta tardia do movimento do osso hióide em relação à chegada do bolo na faringe.

\section{Referências}

1. ALI, S. O.; THOMASSEN, M.; SCHULZ, G. M.; HOSEY, L. A.; VARGA, M.; LUDLOW, C. L.; BRAUN, A. R. Alterations in CNS activity induced by botulinum toxin treatment in spasmodic dysphonia: an $\mathrm{H} 215 \mathrm{O}$ pet study. Journal of Speech, Language, and Hearing Research, Rockville, v. 49, n. 5, p. 1127-1146, 2006.

2. BLITZER, A. Spasmodic dysphonia and botulinum toxin: experience from the largest treatment series. European Journal of Neurology, Oxford, v. 17, n. 1, p. 28-30, 2010.

3. CANNITO, M. P.; KAHANE, J. C.; CHORNA, L. Vocal aging and adductor spasmodic dysphonia: response to botulinum toxin injection. Clinical Interventions in Aging, New Zealand, v. 3, n. 1, p. 131-151, 2008.

4. COSTA, M. M. B. Videofluoroscopy: the gold standard exam for studying swallowing and its dysfunction. Arquivos de Gastroenterologia, São Paulo, v. 47, n. 4, p. 327$328,2010$.

5. DELONG, M. R.; JUNCOS, J. L. Principles of internal medicine. 16th ed. United States: Foreign Language Editions, 2005.

6. ELMIYEH, B.; PRASAD, V. M. N.; UPILE, T.; SAUNDERS, N.; YOUL, B. D.; EPSTEIN, R.; RUBIN, J. S. A single-centre retrospective review of unilateral and bilateral dysport $\circledast$ injections in adductor spasmodic dysphonia. Logopedics, Phoniatrics, Vocology, London, v. 35, n. 1, p. 39-44, 2010.

7. ERTEKIN, C.; AYDOGDU, I.; SEÇIL, Y.; KIYLIOGLU, N.; TARLACl, S.; OZDEMIRKIRAN, T. Oropharyngeal swallowing in craniocervical dystonia. Journal of Neurology, Neurosurgery, and Psychiatry, London, v. 73, n. 4, p. 406-411, 2002.

8. HARRIS, B. M.; BRODSKY, M. B.; MICHEL, Y.; LEE, F. S.; WALTERS, B. Delayed initiation of the pharyngeal swallow: normal variability in adult swallows. Journal of Speech, Language, and Hearing Research, Rockville, v. 50, n. 3, p. 585-594, 2007. 
9. HO, K. H.; WRIGHT, C. C.; UNDERBRINK, M. P. A rare case of laryngeal dystonia associated with neurosyphilis: response to botulinum toxin injection. Laryngoscope, St. Louis, v. 121, n. 1, p. 147-149, 2011.

10. JANKOVIC, J. Treatment of cervical dystonia with botulinum toxin. Movement Disorders, New York, v. 19, n. 8, p. 109-115, 2004.

11. JIMENEZ-SHAHED, J. A new treatment for focal dystonias: incobotulinumtoxin $A$ (xeomin $\left.{ }^{\circledR}\right)$, a botulinum neurotoxin type-A free from complexing proteins. Neuropsychiatric Disease and Treatment, Albany, v. 8, n. 23, p. 13-25, 2012.

12. LARROSA, F.; IDÍGORA, A.; AGUILAR, F.; RIERA, L.; MARTÍ, M. J.; VALLS, J. Results of using botulism toxin in the treatment of spasmodic dysphonia. Acta Otorrinolaringológica Española, Barcelona, v. 53, n. 1, p. 27-31, 2002.

13. LEE, S. Y.; SEO, H. G.; PAIK, N. Botulinum toxin injection for dysphagia: a blinded retrospective videofluoroscopic swallowing study analysis. American Journal of Physical Medicine and Rehabilitation, Baltimore, v. 88, n. 6, p. 491-494, 2009.

14. LUDLOW, C. L. Spasmodic dysphonia: a laryngeal control disorder specific to speech. Journal of Neuroscience, Baltimore, v. 31, n. 3, p. 793-797, 2011.

15. LUDLOW, C. L. Treatment for spasmodic dysphonia: limitations of current approaches. Current Opinion in Otolaryngology \& Head and Neck Surgery, Philadelphia, v. 17, n. 3, p. 160-165, 2009.

16. SCHWEINFURTH, J. M.; BILLANTE, M.; COUREY, M. S. Risk factors and demographics in patients with spasmodic dysphonia. Laryngoscope, St. Louis, v. 112, n. 2, p. 220-223, 2002.

17. SPADOTTO, A. A.; GATTO, A. R.; COLA, P. C.; MONTAGNOLI, A. N.; SCHELP, A. O.; SILVA, R. G.; YAMASHITA, S.; PEREIRA, J. C.; HENRY, M. A. C. A. Software para análise quantitativa da deglutição. Radiologia Brasileira, São Paulo, v. 41, n. 1, p. 25-28, 2008.

18. SVETEL, M.; VASIĆ, M.; TOMIĆ, G.; STANKOVIĆ, P.; STOJANOVIĆ, M.; DRAGASEVIĆ, N.; DERGENC, R.; VUKASINOVIĆ, M.; PEKMEZOVIĆ, T.; PETROVIĆ, I.; KOSTIĆ, V. Botulinum toxin efficacy in the treatment of patients with spasmodic dysphonia. Vojnosanitetski Pregled, Belgrade, v. 64, n. 10, p. 671-675, 2007.

19. THOMAS, J. P.; SIUPSINSKIENE, N. Frozen versus fresh reconstituted botox for laryngeal dystonia. Otolaryngology-Head and Neck Surgery, Rochester, v. 135, n. 2, p. 204-208, 2006.

20. TORRES-RUSSOTTO, D.; PERLMUTTER, J. S. Task-specific dystonias. Annals of the New York Academy of Sciences, New York, v. 1142, n. 10, p. 179-199, 2008.

21. VALE-PRODOMO, L. P. Caracterização videofluoroscópica da fase faríngea da deglutição. 2012. 95 f. Tese (Doutorado) - Fundação Antônio Prudente, São Paulo, 2010. 
22. WATTS, C.R.; NYE, C.; WHURR, R. Botulinum toxin for treating spasmodic dysphonia (laryngeal dystonia): a systematic cochrane review. Clinical Rehabilitation, London, v. 20, n. 2, p. 112-122, 2006.

23. WATTS, C. R.; TRUONG, D. D.; NYE, C. Evidence for the effectiveness of botulinum toxin for spasmodic dysphonia from high-quality research designs. Journal of Neural Transmission, Austria, v. 115, n. 4, p. 625-630, 2008.

24. ZARZUR, A. P.; SHINZATO, G. Laryngeal electromyography: basic principles and new practical applications. Acta Otorrinolaringológica, Barcelona, v. 25, n. 1, p. 0411, 2007. 
Tabela 1 - Comparações dos grupos controle e pacientes com distonia laríngea pré e pós-aplicação da toxina botulínica, considerando os tempos de trânsito para a consistência líquida.

\begin{tabular}{|c|c|c|c|c|c|c|}
\hline \multirow{3}{*}{$\begin{array}{l}\text { Líquida } \\
\text { (ms) }\end{array}$} & \multirow{2}{*}{\multicolumn{2}{|c|}{ Controle }} & \multicolumn{4}{|c|}{ Distonia Laríngea } \\
\hline & & & \multicolumn{2}{|c|}{ Pré - Aplicação } & \multicolumn{2}{|c|}{ Pós - Aplicação } \\
\hline & Média & IC 95\% & Média & IC 95\% & Média & IC 95\% \\
\hline TDPO & 1537 & $1239-1835$ & 1279 & $942-1617$ & 1239 & $876-1602$ \\
\hline TTO & 739 & $624-855$ & 1092 & $914-1270$ & 945 & $797-1093$ \\
\hline TTF & $447 *$ & $423-472$ & 364 & $335-392$ & 356 & $332-381$ \\
\hline TDF & 663 & $634-693$ & 672 & $612-733$ & 706 & $635-776$ \\
\hline TTES & $473^{* *}$ & $448-498$ & 437 & $408-465$ & 407 & $381-434$ \\
\hline $\mathrm{TMH}$ & 1179 & $1098-1260$ & 1372 & $1257-1487$ & 1403 & $1232-1575$ \\
\hline TOFE & 1124 & $1021-1227$ & 1432 & $1262-1603$ & 1312 & $1160-1464$ \\
\hline IFF - IMH & $132^{+}$ & $111-152$ & 221 & $152-290$ & 243 & $175-311$ \\
\hline $\begin{array}{l}* p<0,01 \text { (cc } \\
+p=0,05 \text { (co } \\
\text { TDPO - Tem } \\
\text { TTO - Tempc } \\
\text { TTF - Tempo } \\
\text { TDF - Tempc } \\
\text { TTES - Temp } \\
\text { TMH - Temp } \\
\text { TOFE - Temp }\end{array}$ & $\begin{array}{l}\text { role x pré } \\
\text { role x pós } \\
\text { de prepa } \\
\text { e Trânsit } \\
\text { e trânsito } \\
\text { e depura } \\
\text { de transit } \\
\text { de movim } \\
\text { de transit }\end{array}$ & $\begin{array}{l}\text { pós-aplicação) } \\
\text { plicação) } \\
\text { ção oral. } \\
\text { ral. } \\
\text { ringeo } \\
\text { faríngea. } \\
\text { elo esfíncter es } \\
\text { to do hioide. } \\
\text { orofaríngeo eso }\end{array}$ & $\begin{array}{l}\text { fágico sup } \\
\text { gico }\end{array}$ & $\begin{array}{l}=0,02 \text { (control } \\
\text { Intervalo de } \mathrm{C}\end{array}$ & $\begin{array}{l}\text { x pós-apli } \\
\text { fiança }\end{array}$ & ção) \\
\hline
\end{tabular}


Tabela 2 - Comparações dos grupos controle e pacientes com distonia laríngea pré e pós-aplicação da toxina botulínica considerando os tempos de trânsito para a consistência pastosa.

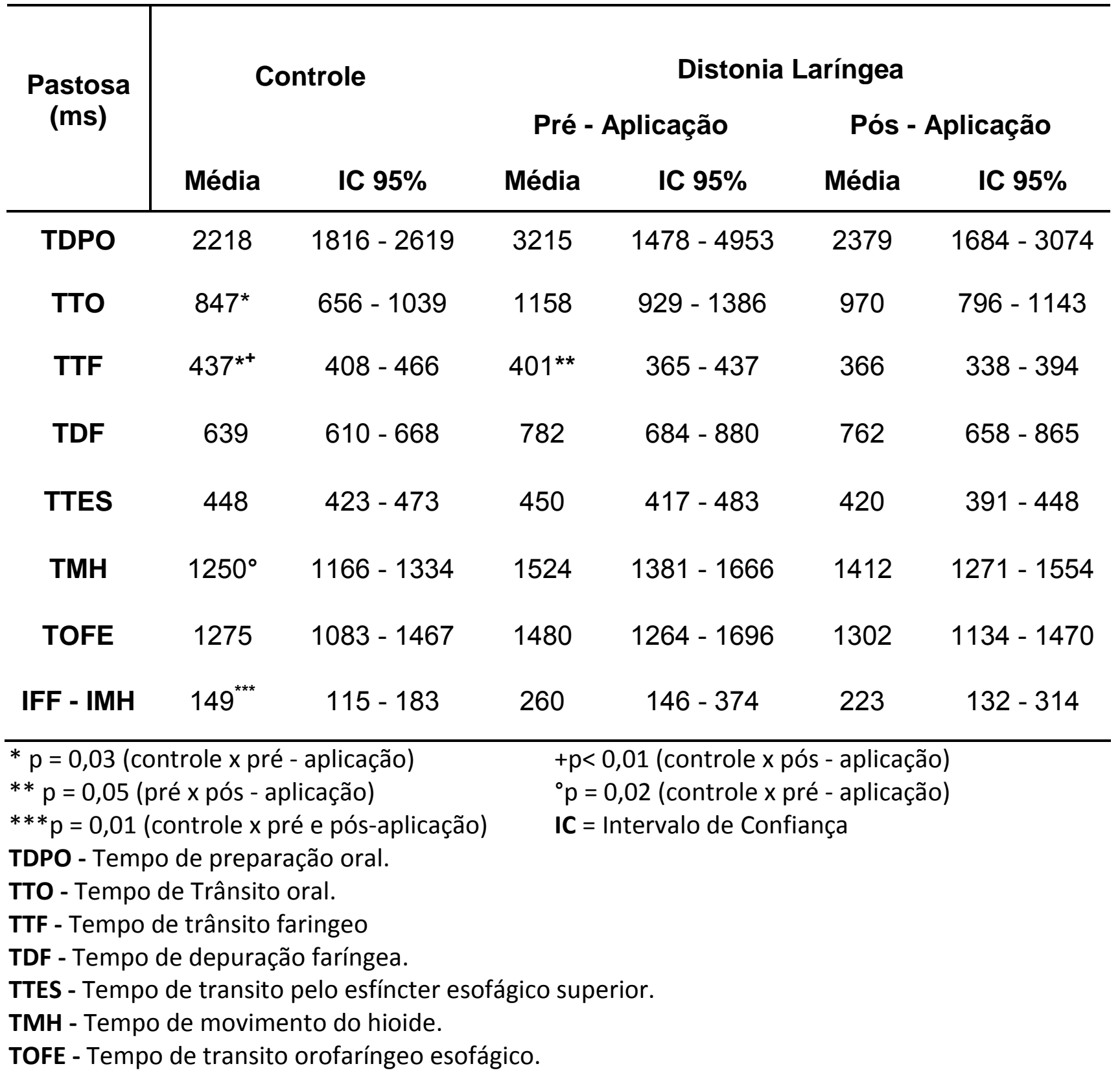


Tabela 3 - Comparação entre os grupos controle, pré-aplicação e pós-aplicação para os resíduos na consistência líquida.

\begin{tabular}{|c|c|c|c|c|c|c|}
\hline \multirow{2}{*}{ Líquida } & \multicolumn{2}{|c|}{ Controle } & \multicolumn{2}{|c|}{ Pré - Aplicação } & \multicolumn{2}{|c|}{ Pós - Aplicação } \\
\hline & $\%$ & $\mathbf{N}$ & $\%$ & $\mathbf{N}$ & $\%$ & $\mathbf{N}$ \\
\hline Resíduo Oral & 15 & 3 & $0^{*}$ & 0 & 0 & 0 \\
\hline Resíduo Oral e Valécula & 75 & 15 & 58,8 & 10 & 47 & 8 \\
\hline $\begin{array}{l}\text { Resíduo Oral, Valécula } \\
\text { e Seios Piriformes }\end{array}$ & 10 & 2 & 41,2 & 7 & $53^{* *}$ & 9 \\
\hline
\end{tabular}

Tabela 4 - Comparação entre os grupos controle, pré-aplicação e pós-aplicação para os resíduos na consistência pastosa.

\begin{tabular}{ccccccc} 
Pastosa & \multicolumn{2}{c}{ Controle } & \multicolumn{2}{c}{ Pré - Aplicação } & \multicolumn{2}{c}{ Pós - Aplicação } \\
& $\%$ & $\mathbf{N}$ & $\%$ & $\mathbf{N}$ & $\%$ & $\mathbf{N}$ \\
\hline Resíduo Oral & 40 & 8 & 17,6 & 3 & 5,8 & 1 \\
Resíduo Oral e Valécula & 55 & 11 & 58,8 & 10 & 58,8 & 10 \\
$\begin{array}{c}\text { Resíduo Oral, Valécula e } \\
\text { Seios Piriformes }\end{array}$ & 5 & 1 & 23,5 & 4 & $35,2^{*}$ & 6 \\
\hline$* 0,01$ (controle x pós-aplicação) & & & & & &
\end{tabular}

Tabela 5 - Comparações entre os grupos controle, pré-aplicação e pós-aplicação para o número de deglutições na consistência pastosa.

\begin{tabular}{ccccccc} 
Número de Deglutições & \multicolumn{2}{c}{ Controle } & \multicolumn{2}{c}{ Pré - Aplicação } & \multicolumn{2}{c}{ Pós - Aplicação } \\
\hline Pastosa & $\%$ & $\mathbf{N}$ & $\%$ & $\mathbf{N}$ & $\%$ & $\mathbf{N}$ \\
$\mathbf{1}$ & 40 & 8 & $0^{*}$ & 0 & 11,7 & 2 \\
$\mathbf{2}$ & 40 & 8 & $88,2^{*}$ & 15 & 52,9 & 9 \\
$\mathbf{3}$ & 15 & 3 & $11,7^{*}$ & 2 & 29,4 & 5 \\
$\mathbf{4}$ & 5 & 1 & 0 & 0 & 5,8 & 1 \\
\hline
\end{tabular}

${ }^{*} p<0,01$ (controle $x$ pré-aplicação). 
Tabela 6 - Comparação entre os grupos controle, pré e pós-aplicação da toxina botulínica, nas consistências líquida e pastosa, considerando a relação entre a duração da depuração faríngea e a duração do movimento do osso hióide.

Controle

Pré - Aplicação

Pós - Aplicação

\begin{tabular}{ccccccc}
\hline Líquida (ms) & Média & IC 95\% & Média & IC 95\% & Média & IC 95\% \\
TCF / TMH & 0,59 & $0,55-0,64$ & 0,52 & $0,46-0,58$ & 0,56 & $0,49-0,62$ \\
Pastosa (ms) & 0,54 & $0,50-0,58$ & 0,55 & $0,48-0,63$ & 0,58 & $0,50-0,66$ \\
TCF / TMH & & & & & &
\end{tabular}
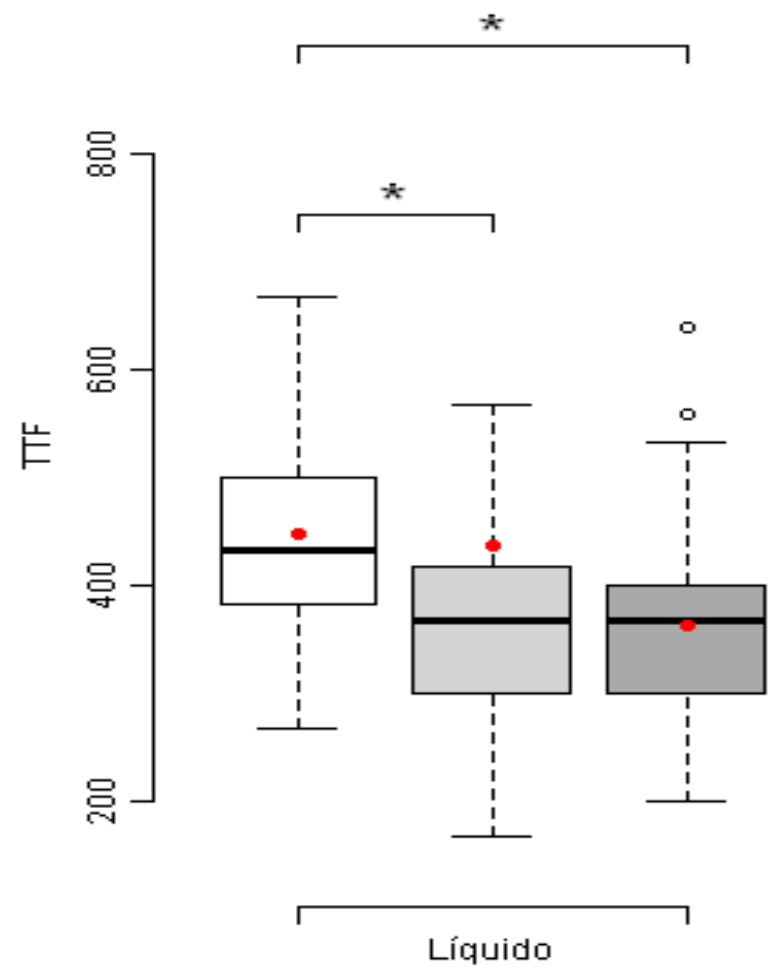
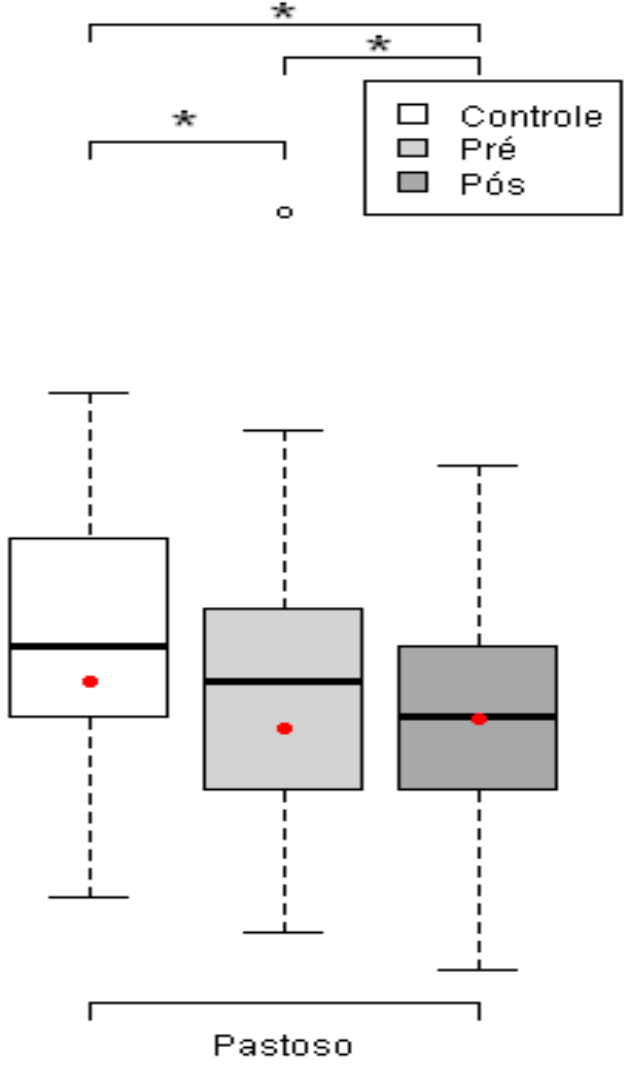

Figura 1 - Comparação do tempo de transito faríngeo (TTF) na deglutição dos bolos líquidos e pastosos nos grupos controle, pré e pós-aplicação da toxina botulínica.
$*: p \leq 0,05$
•: Média : Mediana
TTF - Tempo de transito faringeo em milissegundos. 


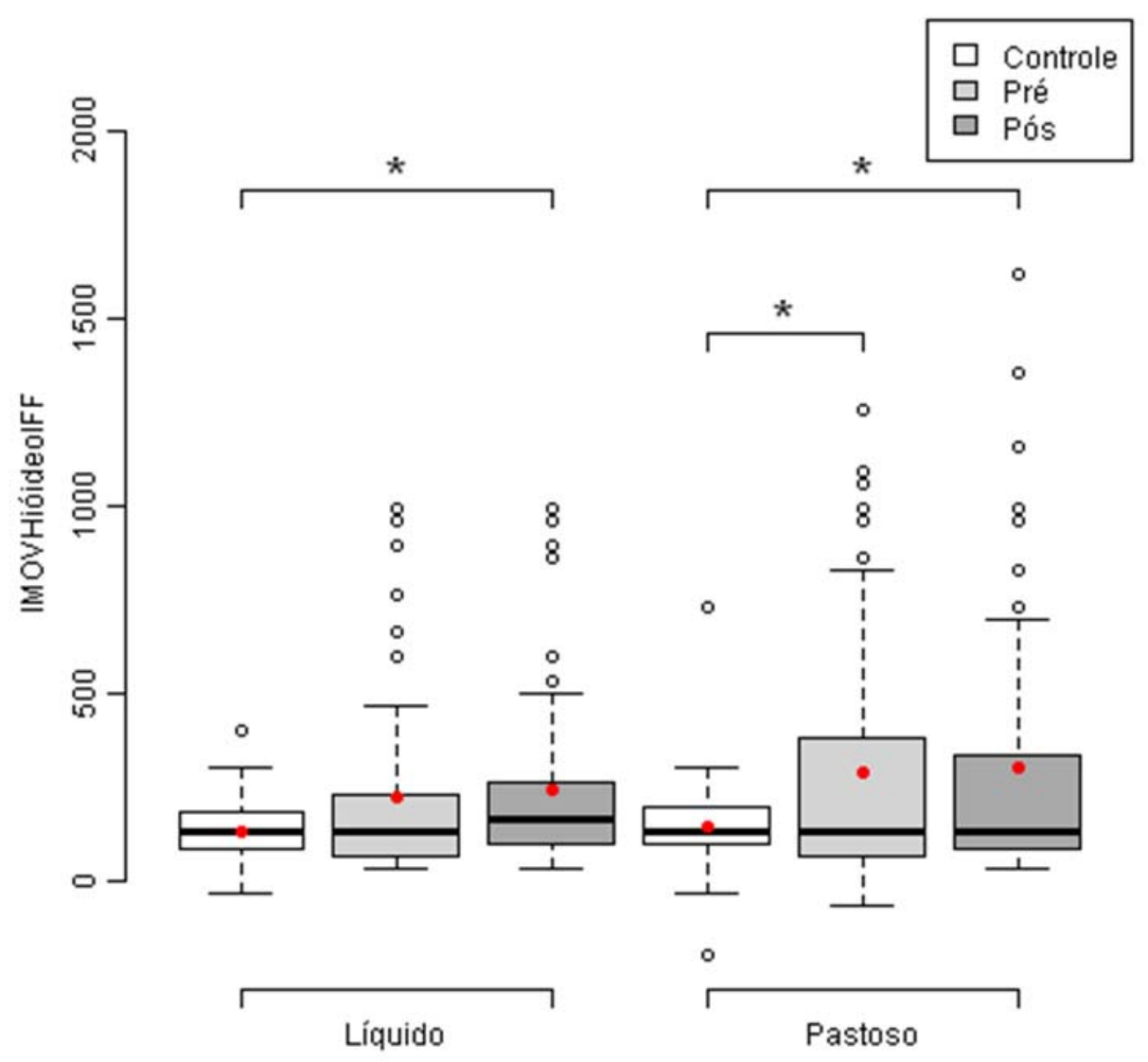

Figura 2 - Relação do inicio da fase faríngea com o inicio do movimento do osso hióide após a deglutição dos bolos líquidos e pastosos nos grupos controle, pré e pós-aplicação da toxina botulínica.

$p=0,05$ (controle $x$ pós-aplicação) $\quad p=0,01$ (controle $x$ pré e pós-aplicação)

$$
\text { -: Média } \quad-\quad \text { : Mediana }
$$

IFF - IMH - Início da fase faríngea e Início do movimento do osso hióide. 